\title{
Data Summary Report for the Semiannual Tritium Survey for Fourmile Branch and the F- and H-Area Seeplines
}

by

J. Koch II

Westinghouse Savannah River Company

Savannah River Site

Aiken, South Carolina 29808

Exploration Resources

This paper was prepared in connection with work done under the above contract number with the U.S. Department of Energy. By acceptance of this paper, the publisher and/or recipient acknowledges the U. S. Government's right to retain a nonexclusive, royalty-free license in and to any copyright covering this paper, along with the right to reproduce and to authorize others to reproduce all or part of the copyrighted paper.

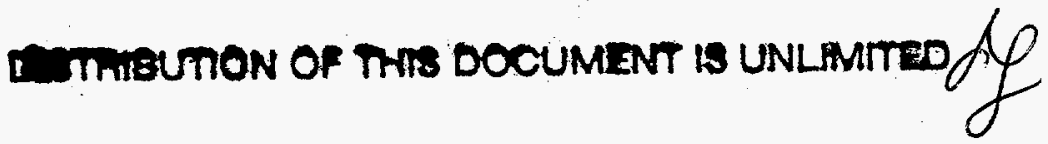




\section{Data Summary Report for the Semiannual Tritium Survey for Fourmile Branch and the F- and H-Area Seeplines}

(U)

December 16, 1996

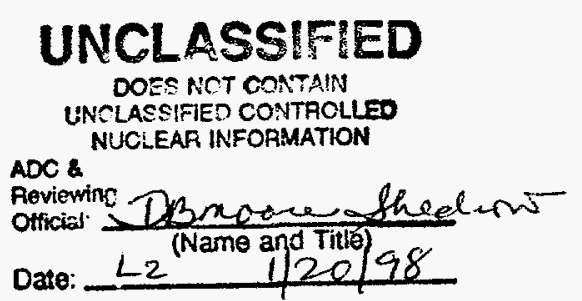




\section{DISCLAIMER}

This report was prepared as an account of work sponsored by an agency of the United States Government. Neither the United States Government nor any agency thereof, nor any of their employees, makes any warranty, express or implied, or assumes any legal liability or responsibility for the accuracy, completeness, or usefulness of any information, apparatus, product, or process disclosed, or represents that its use would not infringe privately owned rights. Reference herein to any specific commercial product, process, or service by trade name, trademark, manufacturer, or otherwise does not necessarily constitute or imply its endorsement, recommendation, or favoring by the United States Government or any agency thereof. The views and opinions of authors expressed herein do not necessarily state or reflect those of the United States Government or any agency thereof.

This report has been reproduced directly from the best available copy.

Available to DOE and DOE contractors from the Office of Scientific and Technical Information, P.O. Box 62, Oak Ridge, TN 37831; prices available from (615) 576-8401.

Available to the public from the National Technical Information Service, U.S. Department of Commerce; 5285 Port Royal Road, Springfield, VA 22161. 


\section{DISCLAIMER}

Portions of this document may be illegible electronic image products. Images are produced from the best available original document. 


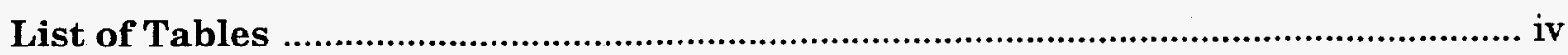

List of Acronyms and Abbreviations ......................................................................... vi

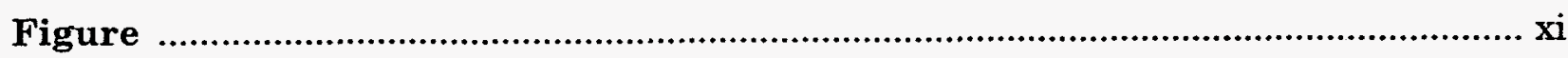

Figure 1. Sampling Locations for Fourmile Branch and the F- and H-Area

Seeplines.......................................................................................................................

Executive Summary ..................................................................................... ES-1

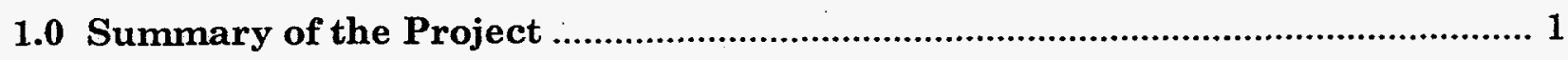

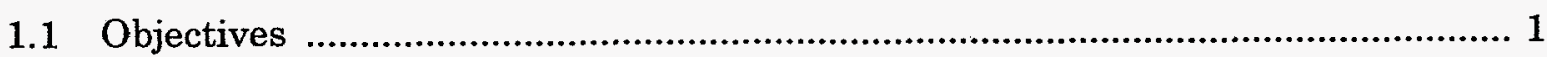

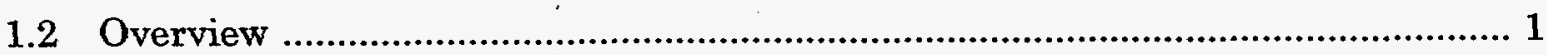

$1.3 \quad$ Field Sampling .............................................................................................. 1

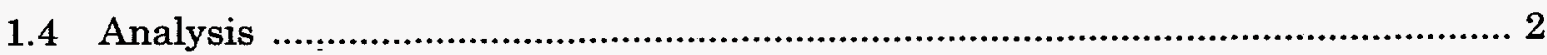

1.5 Validation .............................................................................................. 2

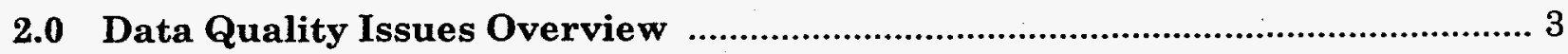

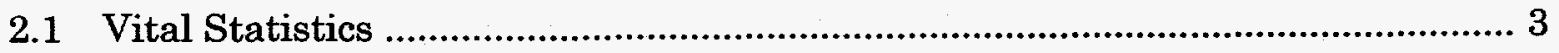

2.2 Program Description ...................................................................................... 3

2.2.1 Verification and Validation Objectives ………………................................. 3

2.2.2 Verification and Validation Functions ............................................................ 4

2.2.3 Laboratories ................................................................................................. 6

2.3 Data Quality Issues Summary ........................................................................... 6

2.3.1 Discrepancies from the Work Plan Assessment ............................................ 6

2.3.2 Sample Documentation ................................................................................. 8

2.3.3 Holding Times and Preservation .................................................................. 8

2.3.4 Analytical Issues ....................................................................................... 8

2.3.5 Rejected Data ............................................................................................... 8

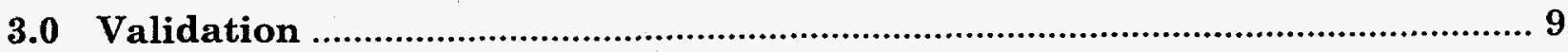

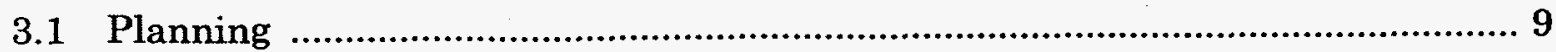

3.1.1 Work Plan Assessment ........................................................................ 9 
3.1.2 Production of Chain-of-Custody Forms ................................................ 9

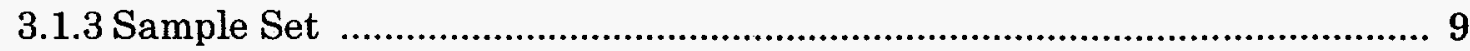

3.2 Field Data Quality Issues .................................................................. 13

3.2.1 Discrepancies from the Work Plan Assessment ................................. 13

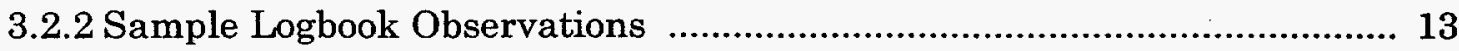

3.2.3 Chain-of-Custody Observations .................................................. 13

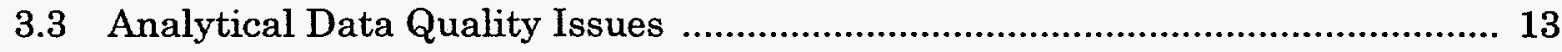

3.3.1 The Laboratories .................................................................... 13

3.3.2 Laboratory Quality Control ....................................................... 14

3.3.3 List of Analytical Suites ......................................................... 14

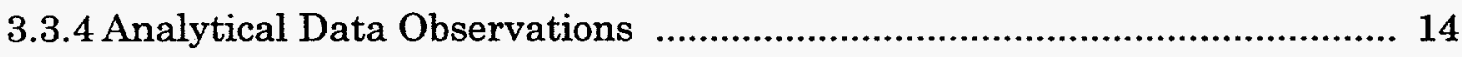

3.4 Verification and Validation Issues ..................................................... 14

3.4.1 Analytical Narrative Review ..................................................... 14

3.4.2 Laboratory Data Records Review ................................................. 15

3.4.3 Qualification of the Data ............................................................ 15

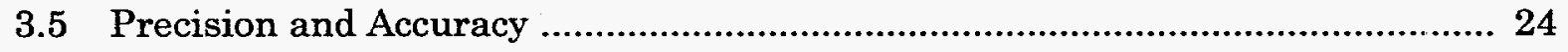

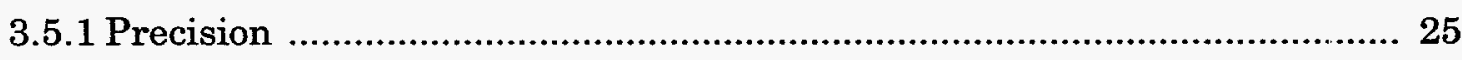

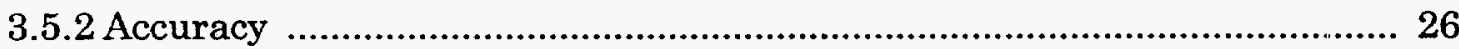

3.5.3 Contamination in Quality Control Samples .................................... 28

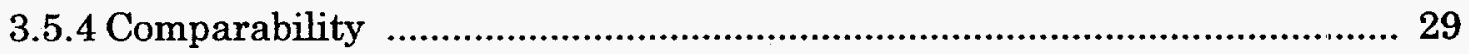

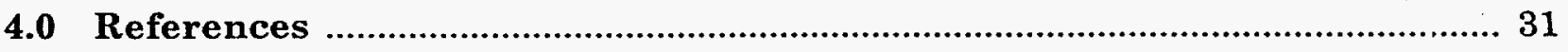

\section{Appendices}

Appendix A: Analytical Methods and Minimum Detectable Activity ................ A-1

Appendix B: Laboratory Performance Evaluation Results ............................ B-1

Appendix C: Formats of the Data Files ............................................................. C-1

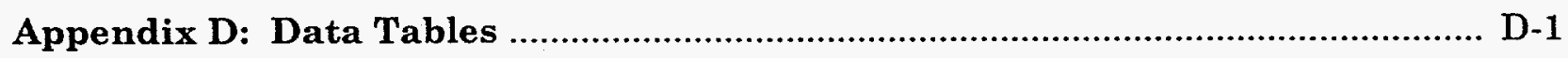

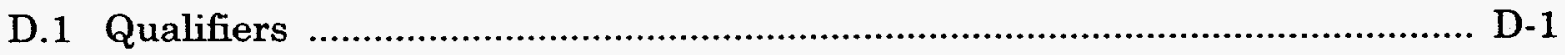

D.2 Number of Qualified Samples ........................................................ D-4

D.3 Analytical Results Sorted by Sample .................................................. D-6 
D.4 Water Results Sorted by Analyte ............................................... D-28

Appendix E: Data Management/Administrative Files .................................... E-1

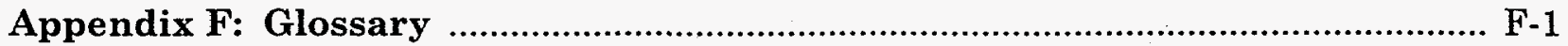




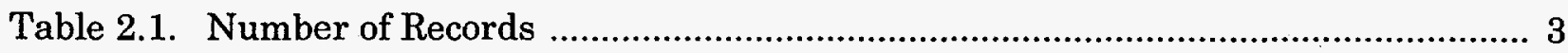

Table 2.2. Samples Not Collected ….................................................................................. 7

Table 2.3. Non-split Samples Sent to EMSL ……............................................................... 7

Table 2.4. QC Sample Locations Changed during Sampling .............................................. 7

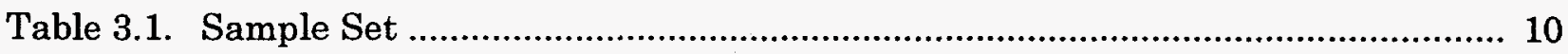

Table 3.2. Laboratory Data Records Review Summary .................................................. 15

Table 3.3. Holding Time Criteria ............................................................................. 16

Table 3.4. Matrix Spikes Rejected due to High Concentration of the Analyte in the Sample by EP ........................................................................................... 22

Table 3.5. Relative Percent Differences of Laboratory Duplicates by EP ......................... 25

Table 3.6. Relative Percent Differences of Field Duplicates by EMSL …………………... 25

Table 3.7. Relative Percent Differences of Field Duplicates by EP .................................. 26

Table 3.8. EPA Quality Control Limits for Laboratory Control Samples ......................... 26

Table 3.9. Laboratory Control Sample Recoveries by EMSL ............................................ 27

Table 3.10. Laboratory Control Sample Recoveries by EP ……........................................ 27

Table 3.11. Matrix Spike Recoveries by EMSL ……............................................................. 28

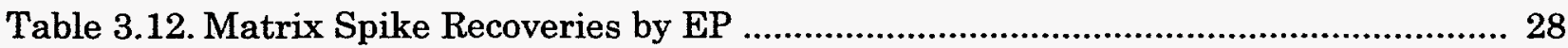

Table 3.13. Analytes Detected in Method Blanks by EMSL ................................................ 28

Table 3.14. Analytes Detected in Method Blanks by EP ....................................................... 29

Table 3.15. Split Sample Results ........................................................................................ 29

Table A.1. Water Analytical Method and MDA for EMSL ................................................ A-1

Table A.2. Water Analytical Method and MDA for EP...................................................... A-1

Table C.1. Sample Data Format SAM93 …......................................................................... C-1

Table C.2. Sample Bottle Data Format SAM93A ……....................................................... C-3

Table C.3. Survey Station Data Format STA93 ….......................................................... C-3

Table C.4. Chain-Of-Custody Data Format COC93 ........................................................ C-4

Table C.5. Analytical Data Format AN95 ……………...................................................... C-4 
Table C.6. Analytical Data AN95-R2 Format ......................................................... C-7

Table C.7. Codes for Laboratory Replicates ............................................................... C-8

Table C.8. Codes for Fractions ................................................................................. C-8

Table C.9. WSRC Identifier for Groundwater Samples .............................................. C-9

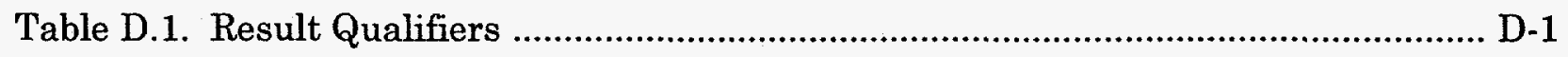

Table D.2. Analysis Qualifiers ...................................................................... D -1

Table D.3. Bias Codes ....................................................................................... D-3

Table D.4. Number of Qualified Samples .............................................................. D-5

Table D.5. Number of Analytical Records by Method and Type of Record ..................... D-5

Table D.6. Analytes Detected in Background and Water Samples .............................. D-5

Table D.7. Water Results Sorted by Sample ............................................................ D-6

Table D.8. Water Results Sorted by Analyte ................................................. D-28 
The following acronyms and abbreviations are used in this QA/QC Summary Report:

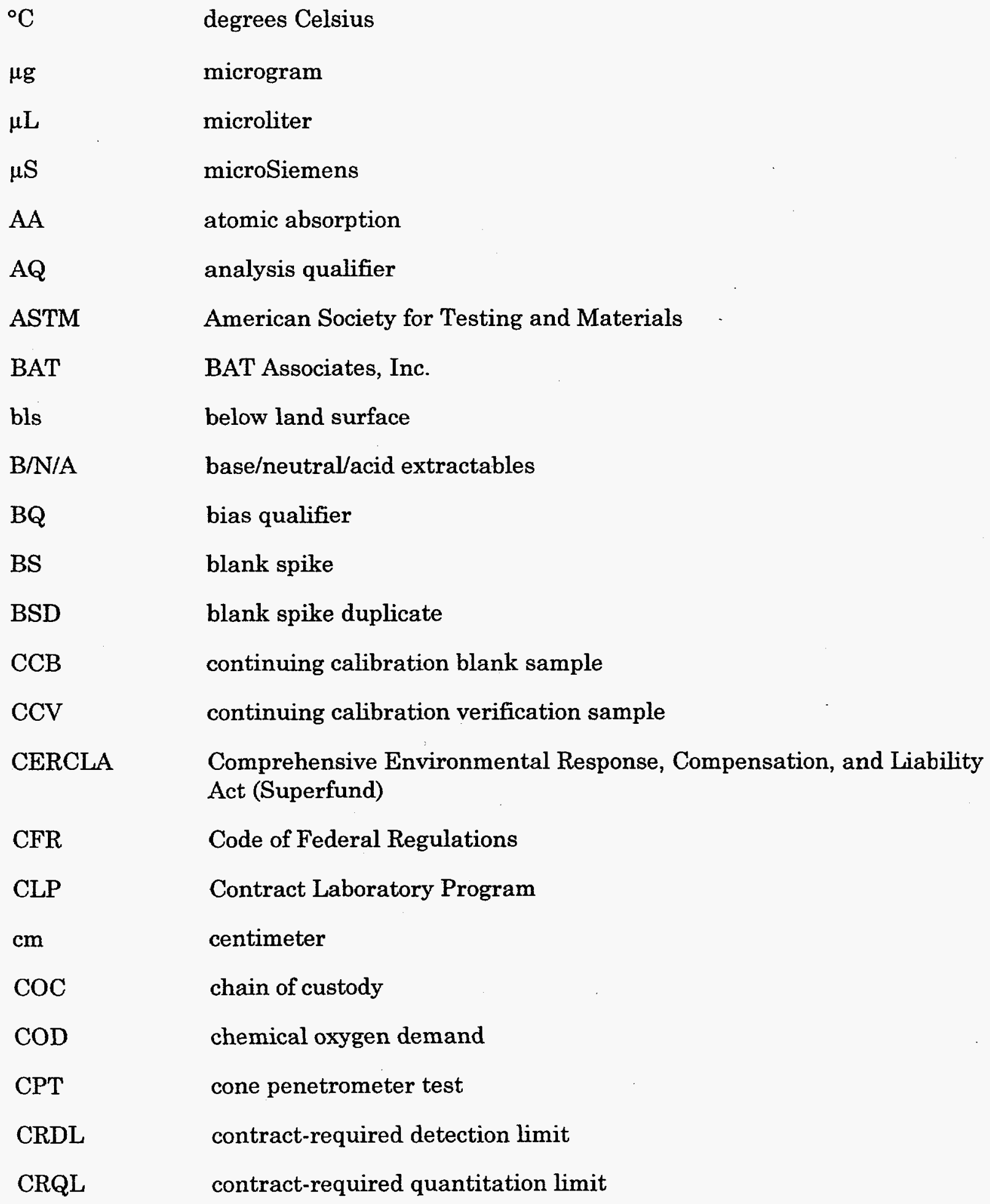


CSDL contract-specified detection limit

CV

coefficient of variation

CVAA cold vapor atomic absorption analysis

DI deionized (water)

DOE United States Department of Energy

dpm disintegrations per minute

DPT direct push technology

DQOs data quality objectives

EDD electronic data deliverable

EGG Environmental Geochemistry Group

Eh oxidation-reduction potential

EM-PPM parts per million methane equivalent

EMSL Environmental Monitoring Section Laboratory

EP Environmental Physics, Inc.

EPA United States Environmental Protection Agency

EPD/EMS Environmental Protection Department/Environmental Monitoring Section

EQL estimated quantitation limit (for non-radiochemistry analyses)

ERA Environmental Resource Associates

ERD Environmental Restoration Department

ESC expedited site characterization

ESS Environmental Support Section

ExR Exploration Resources, Inc.

FHST F- and H-Area Seeplines, Tritium Survey

FID flame ionization detector

$\mathrm{ft} \quad$ feet

g gram

GC gas chromatography 
GC/MS

GE

GFAA

GIMS

GMP

GPC

GPR

ICB

ICP

ICS

ICV

ID

IDL

ISA

ISB

$\mathrm{kg}$

$\mathrm{km}$

L

LCS

LDRR

LIMS

LPQL

$\max$.

MCL

MDA

MDL

meq

mg gas chromatography/mass spectrometry

General Engineering Laboratories, Inc.

graphite furnace atomic absorption (metals analysis)

Geological Information Management System

Groundwater Monitoring Program

gel permeation chromatography

ground penetrating radar

initial calibration blank

inductively coupled plasma (metals analysis)

interference check sample

initial calibration verification

identification

instrument detection limit

ICP interference check sample - interferents only

ICP interference check sample - interferents + analytes

kilogram

kilometer

liter

laboratory control sample

laboratory data records review

laboratory information management system

lowest practical quantitation limit

maximum

maximum contaminant level

minimum detectable activity

method detection limit

milliequivalents

milligram 
min. $\quad$ minimum

$\mathrm{mL} \quad$ milliliter

MRD mean relative difference

MS matrix spike

MSA method of standard addition

MSD matrix spike duplicate

MSL mean sea level

NA not applicable

NAPL non-aqueous phase liquid

ng nanograms

NIST National Institute of Standards and Technology

NTU nephelometric turbidity unit

OVA organic vapor analyzer

PAH polynuclear aromatic hydrocarbons

PAL performance acceptance limit

PCB polychlorinated biphenyl

$\mathrm{pCi} \quad$ picocurries

$\mathrm{PE} \quad$ performance evaluation

PHA pulse-height analysis; e.g., gamma PHA

PID photoionization detector

$\mathrm{ppb} \quad$ parts per billion

ppm parts per million

QA/QC quality assurance/quality control

QA3 data quality objective 3

r correlation coefficient

RCO Radiological Control Officer

RCRA Resource Conservation and Recovery Act

RFI/RI RCRA Facility Investigation/Remedial Investigation 
RPD relative percent difference

$\mathrm{RQ} \quad$ result qualifier

RRT relative retention time

RSD relative standard deviation

RTW retention time window

SAFER Streamlined Approach for Environmental Restoration

SAIC Science Applications International Corporation

SCDHEC South Carolina Department of Health and Environmental Control

SMC sample/method combination

SOP standard operating procedure

SOW statement of work

SQL sample quantitation limit

SRS Savannah River Site

SRTC Savannah River Technology Center

SSC site-specific contaminant

ssEQL sample-specific estimated quantitation limit

std. dev. $\quad$ standard deviation

SW-846 Test Methods for Evaluating Solid Waste

TAL target analyte list

TCL target compound list

TIC tentatively identified compound

U unclassified

UTM Universal Transverse Mercator Zone 17 Coordinate System

VOA volatile organic analyses

VOC volatile organic compound

WA Roy F. Weston, Inc., Analytics Division

WSRC Westinghouse Savannah River Company 


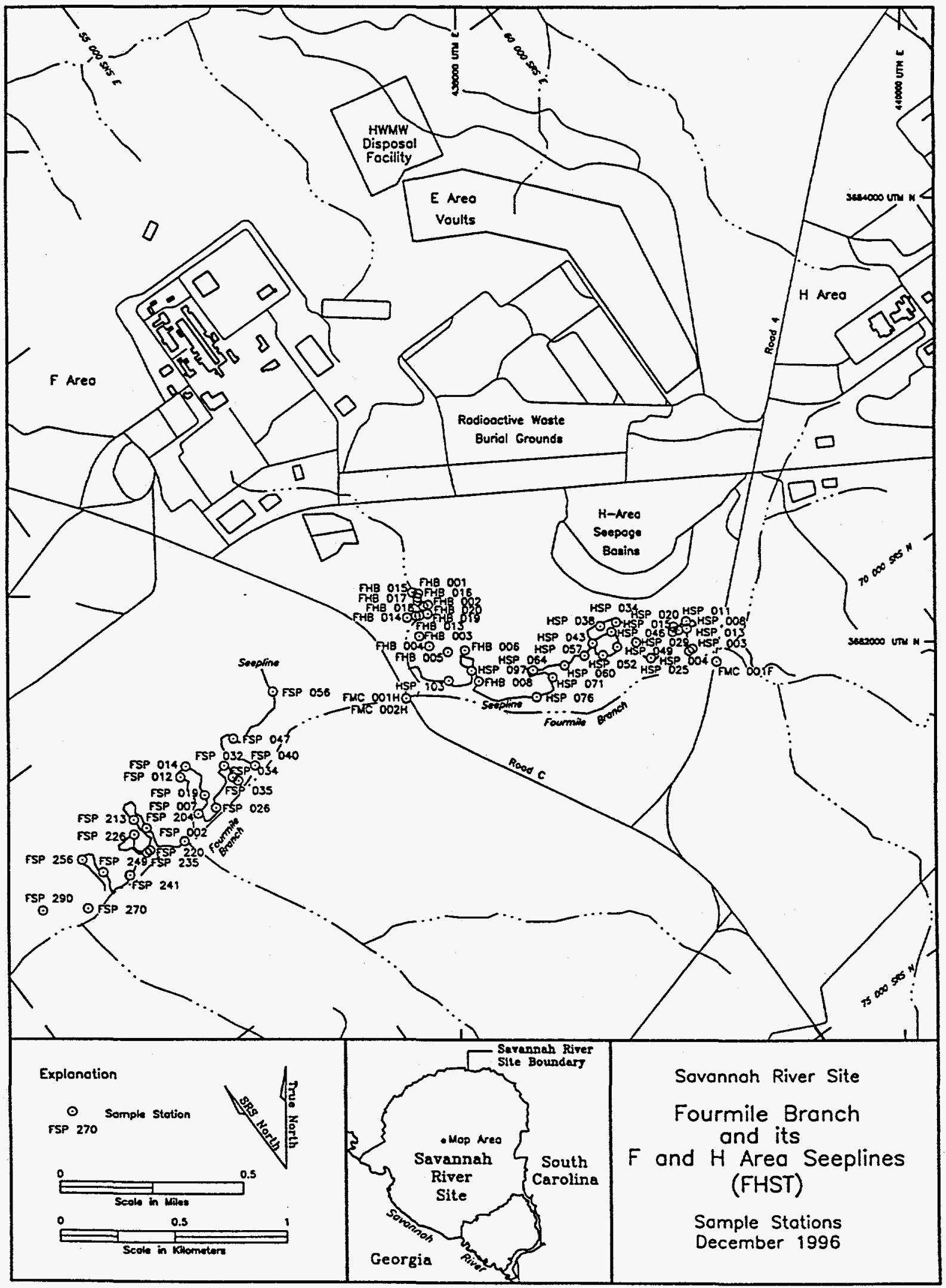

Figure 1. Sampling Locations for Fourmile Branch and the F- and H-Area Seeplines 


\section{Executive Summary}

\section{Purpose}

This report presents a summary of the definitive data validation and verification for the Semiannual Tritium Survey for Fourmile Branch and the F- and H-Area Seeplines (FHST ${ }^{1}$ ). The survey was performed at the request of the WSRC ERD and conducted by WSRC/ESS. This report was prepared under the direction of EPD/EMS.

\section{Scope of the Project}

ExR of Athens, GA, validated and verified sample collection, shipping, and laboratory information compiled for this project. The information compiled, reviewed, and maintained includes the following:

- sample documentation

- COC forms

- sample holding times

- initial and continuing instrument calibration

- analyte identification

- analyte quantitation

- analytical error

- analysis of blanks

- laboratory performance evaluations

- quantitation limits

The validation process began with project mobilization and continued through the delivery of EDDs and this report.

\section{Process and Documentation}

Sample documentation and maintenance of $\mathrm{COC}$ were reviewed by examining the field logs and COC forms. See Section 3.1.2, Production of Chain-of-Custody Forms, of this report for more information about the $\mathrm{COC}$ forms.

1 All acronyms and abbreviations used in this report are defined in the List of Acronyms and Abbreviations (pp. vi-x). 
Sample holding times were checked by comparing the time between sample collection and analysis with a look-up table of required holding times. Analytical instrument calibration was reviewed as part of the LDRR. See Section 3.4.2, Laboratory Data Records Review, of this report for more information about the LDRR.

Analyte identification and analyte quantitation were verified as part of the computerized checking of the EDDs, during review of the analytical narratives, and as part of the LDRR. Anomalies were clarified with the laboratories wherever possible, and records not meeting criteria were qualified. See Section 3.4, Verification and Validation Issues, of this report for further information.

In evaluating analytical error, percent recoveries for $\mathrm{QC}$ samples were reviewed, and the QA/QC sample and associated project sample data were qualified when necessary. Relative percent differences between duplicate sample analyses were calculated. The criteria for qualification are described in Section 3.4.3, Qualification of the Data, of this report.

Laboratory-generated blanks (i.e., method blanks) were examined. Section 3.5.3, Contamination in Quality Control Samples, for a list of all constituents detected in method blanks. Method blanks were performed in ratios of more than one for every 20 samples.

\section{Fourmile Branch and the F- and H-Area Seeplines Affiliates}

The project was completed by the following persons and/or organizations:

- Jim Koch II of WSRC-ESS, Aiken, SC, was the project manager

- WSRC-ESS, Aiken, SC, collected the water samples

- GE of Charleston, SC, and WSRC-EMSL of Aiken, SC, prepared the definitive-level analytical data

- Walt Kubilius of WSRC-EPD/EMS, Aiken, SC, directed the validation of the data and production of the report

- ExR of Athens, GA, validated the data and prepared this report. 


\subsection{Summary of the Project}

\subsection{Objectives}

The objective of this project is to provide validated data for the semiannual tritium sampling events in Fourmile Branch, the F- and H-Area Seeplines, and the 643E Seepline.

\subsection{Overview}

Seepage basins in the $\mathrm{F}$ and $\mathrm{H}$ Areas received low-level radioactive waste effluent from the chemical separation processes in the General Separations Area (WSRC, 1995). The basins retained the effluent to delay its release to the environment. The waste effluent consisted principally of sodium hydroxide, nitric acid, low levels of various radionuclides, and some metals. Discharges of tritiated water to the seepage basins account for most of the radioactivity.

In 1988 and 1989, the Savannah River Laboratory (now the Savannah River Technology Center) conducted an extensive study aimed at characterizing the shallow groundwater outcropping into Fourmile Branch and its associated seeplines. Researchers measured low $\mathrm{pH}$ values, elevated conductivity, and tritium along the seeplines and determined that contaminants leaching from the F-and H-Area seepage basins were impacting the area.

Discharges to the seepage basins were stopped in 1988, and the basins were capped and sealed in 1990 to minimize the release of contaminants to the environment. Scientists hypothesized that after eliminating the contaminant source, annual rainfall amounts and natural groundwater flow would, over time, dilute and flush the remaining contaminant plume out of the shallow groundwater, which would allow recovery of the wetland systems below the basins.

Quarterly sampling of Fourmile Branch and the F- and H-Area seeplines began in May 1992 (WSRC, 1992f). Results from the quarterly tritium surveys, in which $\mathrm{pH}$, specific conductance, and tritium are measured, have shown a significant decrease in tritium activities and specific conductance values, and $\mathrm{pH}$ values have increased to more natural ranges (pH 5-6) when compared to 1989.

Prior to 1996, the tritium analyses were conducted by the EMS laboratory (interoffice memorandum dated February 19, 1996, from J. Koch to C. Nichols, WSRC, SRS, Aiken, $\mathrm{SC}$. Data validation was required, so the tritium analyses were to be performed by an independent outside laboratory.

\subsection{Field Sampling}

Samples of $25 \mathrm{ml}$ each were collected from containers that have been permanently installed at each sample point along the seeplines. There were two sampling events. The first sampling event occurred 3/25/96-4/17/96. The second event occurred 9/17/96-9/24/96. One hundred twenty-nine samples including duplicates and splits were collected. Concurrent 
with the sample collection, $\mathrm{pH}$ and specific conductance were measured in the field and recorded in a logbook.

\subsection{Analysis}

The samples were analyzed for tritium to meet the requirements for definitive-level data. Seventeen samples, one duplicate, and six split samples were analyzed at the EMS laboratory.

\subsection{Validation}

The tritium results were validated as definitive-level data. 


\subsection{Data Quality Issues Overview}

This section provides a summary of the major points affecting the quality of the data for this project.

\subsection{Vital Statistics}

Of the $140 \mathrm{COC}$ forms generated for this project, 129 were used. The 11 unused COC forms were for samples not taken due to insufficient material.

Table 2.1 lists the number of sample and QC records that were qualified after verification and validation were performed.

Table 2.1. Number of Records

\begin{tabular}{|l|l|l|l|}
\hline Data Validation Records & $\begin{array}{l}\text { Sample } \\
\text { Records }\end{array}$ & $\begin{array}{l}\text { QC } \\
\text { Records }\end{array}$ & Total \\
\hline Total Number of Analytical Records & 129 & 46 & 175 \\
\hline Qualified Data & \multicolumn{2}{l|}{} \\
\hline Rejected Analytical Records & 0 & 5 & 5 \\
\hline Result Qualifier $U$ & 2 & 15 & 17 \\
\hline Result Qualifier $J$ & 0 & 0 & 0 \\
\hline Result Qualifier $U J$ & 0 & 0 & 0 \\
\hline
\end{tabular}

\subsection{Program Description}

This section discusses the validation of the data and gives a brief overview of the laboratories.

\subsubsection{Verification and Validation Objectives}

\section{Data Quality Objectives}

Definitive data, as defined in the Data Quality Objectives Process for Superfund, QA/QC Guidance for Removal Activities, have been determined as most appropriate to meet the DQOs of this investigation. Validation and verification activities assessed the data in relation to these standards, especially with regard to the following issues:

- sample documentation

- maintenance of $\mathrm{COC}$

- adherence to sample holding time and preservation requirements

- achievement of contract-required detection limits

- analytical instrument calibration 
- analyte identification

- analyte quantitation

Evaluation of each laboratory's performance for analyte identification and quantitation included examination of analytical error and blank contamination.

Each analytical record in the computer data files contains three qualifier fields: result qualifier, analysis qualifier, and bias qualifier. The result qualifier describes the analytical result. The analysis qualifier describes issues arising during the analytical process. The bias qualifier describes whether the result is biased high or low. The laboratories use these fields in reporting the data. During validation and verification of the analytical data, additional qualifiers may be applied to provide additional information about data quality.

\section{Data Quality Levels}

Definitive-level data are used for data collection activities that require a high degree of qualitative and quantitative accuracy for all findings. Rigorous methods of analysis and quality assurance are used for those samples considered essential in making a decision. This data level is intended to give the decision maker a level of confidence to make decisions based on an action level regarding

- treatment

- disposal

- site remediation and/or removal of pollutants

- health risk or environmental impact

- cleanup verification, pollutant source identification, delineation of contaminants

- other significant decisions where an action level is of concern

Only analyte-specific methods can be used for definitive-level data.

\subsubsection{Verification and Validation Functions}

The data verification process confirms that the required samples were collected and documented, the required analyses were performed on the samples, and the analytical results were reported correctly. The information evaluated during this process includes work plan sample lists, work plan analyte/compound lists, field logbooks, COC forms, and analytical results files.

Data reviewers use computer programs and look-up tables to review the computer data files of sample collection, shipping, and analytical data. The data were examined as follows:

- The following fields were checked to ensure that they were not blank: WSRC sample identification number, sample collection date, laboratory receipt date, analysis date, analysis time, analytical method, laboratory code, laboratory sample identification number, analyte code, result units, nominal concentration, number of dilutions, dilution factor, instrument, instrument batch, and analyst's initials. 
- The following fields were checked to ensure that the data were within an acceptable range of values: WSRC sample identification number, sample collection date, laboratory receipt date, analysis date, analysis time, analytical result, accuracy, number of dilutions, nominal concentration, and bottle number.

- The following fields were checked against a look-up table or a list of valid codes: laboratory code, laboratory duplicate code, analyte code (test name), analytical method, result qualifier, analysis qualifier, analysis bias, result unit, and sample fraction.

The data validation process determines the usefulness of each analytical result based on QA/QC and method requirements. The information evaluated during this process includes COC forms, analytical narrative summaries, analytical result data files, and raw result and calibration data.

Data validation involves evaluating requirements in the following $\mathrm{QA} / \mathrm{QC}$ categories: holding times, instrument calibration, analyte identification/quantitation, method blanks, laboratory control samples, duplicates (field and laboratory), matrix spikes, surrogates, and internal standards.

Data validation and qualification policies were developed from the following sources: EPA, 1986; EPA, 1988a; EPA, 1988b; EPA, 1990b; EPA, 1991b; contract-specific WSRC requirements; and discussions with laboratory personnel.

\section{Data Qualifiers}

When analytical data are validated, the analytical results and the associated QC information are reviewed using criteria specific to the analysis performed. Data qualifiers are used during the data validation process to classify sample data as conforming to $\mathrm{QC}$ requirements.

The qualifiers used for data associated with this project are defined in Appendix $D$.

\section{Precision}

Precision measures the reproducibility of measurements under a given set of conditions. It is a quantitative measure of the variability of a group of measurements compared to its average value. Precision is reported in terms of the relative percent difference. The analytical results from the field replicate samples provide data or overall measurement precision; analytical results from the laboratory duplicates provide data on analytical precision.

\section{Accuracy}

Accuracy measures the bias in a measurement system; it is difficult to measure for the entire data collection activity. Sources of error are the sampling process, field contamination, preservation, handling, sample matrix, sample preparation, and sample analysis techniques. Sampling accuracy may be assessed by evaluating the results of rinsates, field blanks, and trip blanks. Analytical accuracy may be assessed through the use of known and unknown QC samples, matrix spikes, and method blanks. 


\section{Representativeness}

Representativeness expresses the degree to which sample data accurately and precisely represent a characteristic of a population, parameter variations at a sampling point, or an environmental condition. Representativeness is a qualitative parameter that is most concerned with the proper design of the sampling program and is best satisfied by making certain that sampling locations are selected properly and that a sufficient number of samples is collected.

The sampling and analysis plan (interoffice memorandum dated November 4, 1996 from J. Koch to W. Kubilius, WSRC, SRS, Aiken, SC) and work plan assessment (Nichols and Conner, 1996) describe the sample selection process.

\section{Completeness}

Completeness is defined as the percentage of measurements made that are judged to be valid measurements. It is important that critical samples are identified and that plans are made to achieve valid data for them. Completeness was not determined for this report.

\section{Comparability}

Comparability is a qualitative parameter expressing the confidence with which one data set can be compared with another. Sample data should be comparable with other measurement data for similar samples and sample conditions. This goal is achieved through using standard techniques to collect and analyze representative samples and through reporting analytical results in appropriate units.

\subsubsection{Laboratories}

The following laboratories generated the analytical data for FHST.

GE of Charleston, SC, the primary laboratory, provided definitive-level radiological analyses under contract AA07208N. EP, a subsidiary of GE, performed the analyses.

EMSL of Aiken, SC, the secondary laboratory, provided definitive-level radionuclide analyses.

\subsection{Data Quality Issues Summary}

This section provides a summary of the major data quality issues identified during the verification and validation process.

\subsubsection{Discrepancies from the Work Plan Assessment}

Ten environmental samples listed in the work plan assessment could not be collected because the sample locations were dry, and there was insufficient volume to fill the sample bottles. The following table lists the samples that were not collected. 
Table 2.2. Samples Not Collected

\begin{tabular}{|l|l|}
\hline Sample ID & Survey Station ID \\
\hline 106511 & FHB 1501 \\
\hline 106545 & HSP 3801 \\
\hline 108931 & HSP 3402 \\
\hline 108932 & HSP 3802 \\
\hline 108933 & HSP 4302 \\
\hline 108937 & HSP 6002 \\
\hline 108945 & FHB 1502 \\
\hline 108946 & FHB 0102 \\
\hline 108949 & FHB 1902 \\
\hline 108969 & HSP 1102 \\
\hline
\end{tabular}

According to the work plan assessment only the split samples were to be sent to EMSL. However, ten environmental samples and one duplicate known to have high tritium concentrations were sent to EMSL because of difficulties shipping radiological samples above $2000 \mathrm{pCi} / \mathrm{mL}$ to off-site laboratories (interoffice memorandum dated November 4, 1996 from J. Koch to W. Kubilius, WSRC, SRS, Aiken, SC). These samples are listed in the following table.

Table 2.3. Non-split Samples Sent to EMSL

\begin{tabular}{|l|l|}
\hline Sample ID & $\begin{array}{l}\text { Survey } \\
\text { Station ID }\end{array}$ \\
\hline 108900 & FSP 20402 \\
\hline 108901 & FSP 21302 \\
\hline 108914 & FSP 1902 \\
\hline 108915 & FSP 2602 \\
\hline 108916 & FSP 2602A \\
\hline 108918 & FSP 3502 \\
\hline
\end{tabular}

\begin{tabular}{|l|l|}
\hline Sample ID & $\begin{array}{l}\text { Survey } \\
\text { Station ID }\end{array}$ \\
\hline 108919 & FSP 4002 \\
\hline 108947 & FHB 1702 \\
\hline 108948 & FHB 1802 \\
\hline 108950 & FHB 1302 \\
\hline 108952 & FHB 1202 \\
\hline
\end{tabular}

The required rate of one per ten duplicates and splits was met for this project. However, there were six QC sample locations that deviated from the work plan assessment. During sampling, the QC samples were collected from alternate locations. The following table lists the planned QC sample locations and the alternate sample locations.

Table 2.4. QC Sample Locations Changed during Sampling

\begin{tabular}{|l|l|}
\hline Planned QC Sample Location & Alternate QC Sample Location \\
\hline FSP 5601A & FHB 2001A \\
\hline FSP 4001D & FMC 2H01D \\
\hline FMC 1H01A & HSP 5701D \\
\hline FHB 1802A & HSP 5202A \\
\hline
\end{tabular}


Table 2.4. QC Sample Locations Changed during Sampling, continued

\begin{tabular}{|l|l|}
\hline Planned QC Sample Location & Alternate QC Sample Location \\
\hline HSP 6402A & HSP 9702A \\
\hline HSP 10302D & FHB 0602D \\
\hline
\end{tabular}

\subsubsection{Sample Documentation}

The split sample (FMC 2H01D) for sample FMC 2H01 was collected six days after the parent sample was collected.

\subsubsection{Holding Times and Preservation}

No holding times were exceeded for this project.

There are no temperature requirements for tritium water samples.

\subsubsection{Analytical Issues}

No significant analytical issues were encountered during verification and validation of the FHST analytical data.

\subsubsection{Rejected Data}

No environmental samples were rejected for this project. Five matrix spike records were rejected because the sample concentration exceeded the spike concentration by a factor of four. 


\subsection{Planning}

A work plan assessment (Nichols and Conner, 1996) consistent with WSRC EGG Operating Handbook, Section 2.110, Work Plan Assessment, was conducted by Chet Nichols of WSRC and Steven P. Conner of SAIC.

\subsubsection{Work Plan Assessment}

Water samples were to be collected for two sampling events from 63 sampling locations. Samples were to be collected from the F-Area seepline, the H-Area seepline, 643E seepline, and background locations. Samples of $25 \mathrm{~mL}$ each were collected from permanently installed containers or field augered holes at each sample point along the seeplines.

Sample splits and duplicates were planned at a frequency of one per 10 samples. Eight duplicates and six splits were planned.

The samples were to be analyzed for tritium. These data were validated as definitive-level data.

\subsubsection{Production of Chain-of-Custody Forms}

COC forms containing the list of requested analyses for each planned sample were printed on waterproof paper. A printed tear-off stub attached to the COC form stipulated the sample collection location. Information completed on the COC forms included the following:

- EMS sample identification number from the logbook page for that sample

- laboratory sample identification number (to be completed by the laboratory)

- sample collection date

- shipping information including the signatures and dates of each person handling the sample

- the cooler number and temperature upon arrival at the analytical laboratory

A peel-off section of each bottle label, printed with the bottle number, was affixed to the analysis request line on the COC form. As specified in the Work Plan Assessment, 140 COCs were generated for this project.

\subsubsection{Sample Set}

The following table lists the sample identifiers, sample type, sample date and time, and the analyses requested for samples sent to the laboratory. 
Table 3.1. Sample Set

\begin{tabular}{|c|c|c|c|c|c|}
\hline $\begin{array}{l}\text { Survey } \\
\text { Station ID }\end{array}$ & Sample ID & Laboratory ID & Sample Type & $\begin{array}{l}\text { Sample Date } \\
\text { and Time }\end{array}$ & $\begin{array}{l}\text { Analyses } \\
\text { Requested }\end{array}$ \\
\hline \multicolumn{6}{|c|}{ First Sampling Event } \\
\hline FHB 0101 & 106500 & $9604371-04$ & Water & $03 / 25 / 96,12: 30$ & Tritiun \\
\hline FHB 0201 & 106501 & 9604371-03 & Water & $03 / 25 / 96,12: 40$ & Tritiun \\
\hline FHB 0201D & 106502 & 960847402 & Split & $03 / 25 / 96,12: 41$ & Tritiun \\
\hline FHB 0301 & 106512 & 9604371-06 & Water & $03 / 25 / 96,12: 51$ & Tritiunn \\
\hline FHB 0401 & 106513 & $9604371-15$ & Water & 03/25/96, 13:00 & Tritiun \\
\hline FHB 0501 & 106515 & $9604371-32$ & Water & $03 / 25 / 96,13: 50$ & Tritiun \\
\hline FHB 0601 & 106514 & 9604371-31 & Water & $03 / 25 / 96,13: 45$ & Tritium \\
\hline FHB 0801 & 106516 & 9604371-39 & Water & $03 / 25 / 96,14: 00$ & Tritiun \\
\hline FHB 1201 & 106506 & 9604486-01 & Water & $03 / 25 / 96,11: 50$ & Tritiunn \\
\hline FHB 1301 & 106505 & $9604486-02$ & Water & $03 / 25 / 96,11: 45$ & Tritiun \\
\hline FHB 1401 & 106507 & 9604371-02 & Water & $03 / 25 / 96,11: 55$ & Tritium \\
\hline FHB 1601 & 106510 & $9604371-38$ & Water & $03 / 25 / 96,12: 15$ & Tritium \\
\hline FHB 1701 & 106509 & 9604486-03 & Water & $03 / 25 / 96,12: 10$ & Tritium \\
\hline FHB 1801 & 106508 & 9604486-04 & Water & $03 / 25 / 96,12: 00$ & Tritium \\
\hline FHB 1901 & 106504 & $9604486-05$ & Water & $03 / 25 / 96,11: 37$ & Tritium \\
\hline FHB 2001 & 106503 & $9604371-01$ & Water & $03 / 25 / 96,11: 30$ & Tritium \\
\hline FHB 2001A & 106542 & $9604371-11$ & Duplicate & $03 / 25 / 96,11: 30$ & Tritium \\
\hline FMC 1F01 & 106539 & 9604371-14 & Water & $03 / 27 / 96,10: 12$ & Tritium \\
\hline FMC $1 \mathrm{H01}$ & 106562 & 9604371-46 & Water & $04 / 10 / 96,13: 15$ & Tritium \\
\hline FMC $2 \mathrm{H} 01$ & 106567 & 9604371-24 & Water & 04/11/96, 09:01 & Tritium \\
\hline FMC 2H01D & 106568 & 9680847502 & Split & $04 / 17 / 96,11: 05$ & Tritiun \\
\hline FSP 0201 & 106528 & 9604371-12 & Water & $03 / 26 / 96,12: 34$ & Tritiun \\
\hline FSP 0201A & 106529 & 9604371-34 & Duplicate & $03 / 26 / 96,12: 35$ & Tritium \\
\hline FSP 0701 & 106527 & $9604371-16$ & Water & $03 / 26 / 96,12: 24$ & Tritiun \\
\hline $\begin{array}{|ll|}\text { FSP } & 1201 \\
\end{array}$ & 106530 & 9604371-19 & Water & $03 / 26 / 96,12: 46$ & Tritiun \\
\hline $\begin{array}{|ll|}\text { FSP } 1401 \\
\end{array}$ & 106534 & $9604371-07$ & Water & $03 / 26 / 96,13: 55$ & Tritium \\
\hline FSP 1901 & 106531 & 9604486-06 & Water & 03/26/96, 13:01 & Tritium \\
\hline FSP 2601 & 106533 & 9604486-07 & Water & $03 / 26 / 96,13: 26$ & Tritium \\
\hline FSP 3201 & 106532 & 9604371-09 & Water & $03 / 26 / 96,13: 12$ & Tritium \\
\hline FSP 3401 & 106566 & $9604371-10$ & Water & $04 / 11 / 96,08: 49$ & Tritium \\
\hline $\begin{array}{|ll|}\text { FSP } 3501 \\
\end{array}$ & 106537 & 9604486-08 & Water & $03 / 26 / 96,14: 39$ & Tritium \\
\hline FSP 4001 & 106536 & 9604486-09 & Water & $03 / 26 / 96,14: 31$ & Tritium \\
\hline FSP 4701 & 106535 & $9604371-41$ & Water & $03 / 26 / 96,14: 14$ & Tritium \\
\hline FSP 5601 & 106538 & $9604371-29$ & Water & 03/26/96, 15:03 & Tritium \\
\hline FSP 20401 & 106517 & $9604486-10$ & Water & $03 / 26 / 96,08: 39$ & Tritium \\
\hline FSP 21301 & 106518 & $9604486-11$ & Water & $03 / 26 / 96,08: 57$ & Tritium \\
\hline FSP 22001 & 106520 & $9604371-28$ & Water & $03 / 26 / 96,09: 12$ & Tritium \\
\hline FSP 22601 & 106519 & $9604371-18$ & Water & $03 / 26 / 96,09: 02$ & Tritium \\
\hline
\end{tabular}


Table 3.1. Sample Set, continued

\begin{tabular}{|c|c|c|c|c|c|}
\hline \begin{tabular}{|l} 
Survey \\
Station ID
\end{tabular} & Sample ID & Laboratory ID & Sample Type & $\begin{array}{l}\text { Sample Date } \\
\text { and Time }\end{array}$ & $\begin{array}{l}\text { Analyses } \\
\text { Requested }\end{array}$ \\
\hline FSP 23501 & 106522 & $9604371-05$ & Water & $03 / 26 / 96,09: 36$ & Tritium \\
\hline FSP 24101 & 106521 & $9604371-40$ & Water & $03 / 26 / 96,09: 26$ & Tritium \\
\hline FSP 24901 & 106526 & $9604371-43$ & Water & $03 / 26 / 96,11: 17$ & Tritium \\
\hline FSP 25601 & 106525 & 9604371-17 & Water & $03 / 26 / 96,11: 07$ & Tritium \\
\hline FSP 27001 & 106524 & 9604371-20 & Water & $03 / 26 / 96,10: 26$ & Tritium \\
\hline FSP 29001 & 106523 & $9604371-33$ & Water & $03 / 26 / 96,10: 17$ & Tritium \\
\hline HSP 0301 & 106559 & $9604371-27$ & Water & $04 / 10 / 96,12: 51$ & Tritium \\
\hline HSP 0401 & 106560 & 9604371-37 & Water & $04 / 10 / 96,12: 58$ & Tritium \\
\hline HSP 0401A & 106561 & 9604371-23 & Duplicate & $04 / 10 / 96,12: 59$ & Tritium \\
\hline HSP 0801 & 106557 & $9604486-18$ & Water & $04 / 10 / 96,12: 23$ & Tritium \\
\hline HSP 1101 & 106558 & 9604371-21 & Water & 04/10/96, 12:27 & Tritium \\
\hline HSP 1301 & 106556 & $9604486-12$ & Water & $04 / 10 / 96,12: 12$ & Tritium \\
\hline HSP 1501 & 106555 & 9604371-36 & Water & $04 / 10 / 96,12: 05$ & Tritium \\
\hline HSP 2001 & 106554 & $9604371-45$ & Water & 04/10/96, 11:51 & Tritium \\
\hline HSP 2501 & 106553 & $9604371-44$ & Water & $04 / 10 / 96,11: 45$ & Tritium \\
\hline HSP 2901 & 106552 & 9604371-08 & Water & $04 / 10 / 96,11: 34$ & Tritium \\
\hline HSP 3401 & 106551 & $9604371-26$ & Water & $04 / 10 / 96,11: 24$ & Tritium \\
\hline HSP 4301 & 106544 & 9604486-13 & Water & 04/10/96, 09:38 & Tritium \\
\hline HSP 4601 & 106546 & 9604371-30 & Water & $04 / 10 / 96,10: 01$ & Tritium \\
\hline HSP 4901 & 106548 & 9604486-14 & Water & $04 / 10 / 96,10: 20$ & Tritium \\
\hline HSP 5201 & 106547 & 9604486-15 & Water & 04/10/96, 10:14 & Tritium \\
\hline HSP 5701 & 106549 & 9604371-13 & Water & $04 / 10 / 96,10: 38$ & Tritium \\
\hline HSP 5701D & 106550 & 9680847302 & Split & $04 / 10 / 96,10: 40$ & Tritium \\
\hline HSP 6001 & 106540 & 9604486-16 & Water & $03 / 27 / 96,10: 32$ & Tritium \\
\hline HSP 6401 & 106541 & 9604371-35 & Water & $03 / 27 / 96,10: 43$ & Tritium \\
\hline HSP 7101 & 106563 & 9604371-25 & Water & 04/10/96, 13:40 & Tritium \\
\hline HSP 7601 & 106543 & $9604371-22$ & Water & $03 / 27 / 96,10: 58$ & Tritium \\
\hline HSP 9701 & 106565 & $9604486-17$ & Water & $04 / 10 / 96,14: 30$ & Tritium \\
\hline HSP 10301 & 106564 & $9604371-42$ & Water & $04 / 10 / 96,14: 25$ & Tritium \\
\hline \multicolumn{6}{|c|}{ Second Sampling Event } \\
\hline \begin{tabular}{|lll} 
FHB & 0202 \\
\end{tabular} & 108943 & $9609541-37$ & Water & $09 / 19 / 96,11: 10$ & Tritium \\
\hline FHB 0302 & 108953 & $9609541-40$ & Water & 09/19/96, 13:15 & Tritium \\
\hline FHB 0402 & 108954 & $9609541-41$ & Water & $09 / 19 / 96,13: 25$ & Tritium \\
\hline FHB 0502 & 108960 & $9609541-42$ & Water & $09 / 19 / 96,14: 35$ & Tritium \\
\hline FHB 0602 & 108958 & $9609541-01$ & Water & $09 / 19 / 96,14: 20$ & Tritium \\
\hline FHB 0602D & 108959 & 9680977802 & Split & $09 / 19 / 96,14: 21$ & Tritium \\
\hline FHB 0802 & 108961 & $9609541-43$ & Water & $09 / 19 / 96,14: 55$ & Tritium \\
\hline FHB 1202 & 108952 & 9680143000 & Water & $09 / 19 / 96,12: 07$ & Tritium \\
\hline FHB 1302 & 108950 & 9680142900 & Water & $09 / 19 / 96,12: 00$ & Tritium \\
\hline FHB 1402 & 108951 & 9609541-39 & Water & $09 / 19 / 96,12: 05$ & Tritium \\
\hline
\end{tabular}


Table 3.1. Sample Set, continued

\begin{tabular}{|c|c|c|c|c|c|}
\hline $\begin{array}{l}\text { Survey } \\
\text { Station ID }\end{array}$ & Sample ID & Laboratory ID & Sample Type & $\begin{array}{l}\text { Sample Date } \\
\text { and Time }\end{array}$ & $\begin{array}{l}\text { Analyses } \\
\text { Requested }\end{array}$ \\
\hline FHB 1602 & 108944 & 9609541-38 & Water & 09/19/96, 11:30 & Tritiurn \\
\hline FHB 1702 & 108947 & 9680143100 & Water & $09 / 19 / 96,11: 45$ & Tritiurn \\
\hline FHB 1802 & 108948 & 9680144500 & Water & $09 / 19 / 96,11: 50$ & Tritiurn \\
\hline FHB 2002 & 108942 & 9609541-35 & Water & $09 / 19 / 96,11: 05$ & Tritiurn \\
\hline FMC 1F02 & 108964 & $9609541-44$ & Water & $09 / 23 / 96,12: 31$ & Tritiurn \\
\hline FMC $1 \mathrm{HO2}$ & 108962 & $9609541-45$ & Water & $09 / 23 / 96,11: 59$ & Tritiumn \\
\hline FMC 2H02 & 108963 & $9609541-46$ & Water & $09 / 23 / 96,12: 11$ & Tritiurn \\
\hline FMC 2H02D & 108966 & 9680977900 & Split & $09 / 23 / 96,12: 12$ & Tritiurn \\
\hline FSP 0202 & 108911 & 9609541-10 & Water & $09 / 18 / 96,07: 45$ & Tritiurn \\
\hline FSP 0702 & 108912 & $9609541-11$ & Water & $09 / 18 / 96,07: 55$ & Tritiurn \\
\hline FSP 1202 & 108913 & $9609541-12$ & Water & 09/18/96, 08:05 & Tritiurn \\
\hline FSP 1402 & 108921 & 9609541-15 & Water & $09 / 18 / 96,11: 30$ & Tritiurn \\
\hline FSP 1902 & 108914 & 9680144900 & Water & 09/18/96, 08:30 & Tritiurn \\
\hline FSP 2602 & 108915 & 9680142700 & Water & 09/18/96, 08:35 & Tritiurn \\
\hline FSP 2602A & 108916 & 9680142600 & Duplicate & 09/18/96, 08:36 & Tritiurn \\
\hline FSP 3202 & 108917 & $9609541-13$ & Water & 09/18/96, 08:50 & Tritiurn \\
\hline FSP 3402 & 108967 & $9609541-47$ & Water & $09 / 24 / 96,12: 21$ & Tritiurn \\
\hline FSP 3502 & 108918 & 9680142400 & Water & 09/18/96, 09:00 & Tritiurn \\
\hline FSP 4002 & 108919 & 9680142800 & Water & $09 / 18 / 96,09: 11$ & Tritiurn \\
\hline FSP 4702 & 108920 & 9609541-14 & Water & $09 / 18 / 96,09: 50$ & Tritiurn \\
\hline FSP 5602 & 108922 & $9609541-16$ & Water & $09 / 18 / 96,11: 50$ & Tritiurn \\
\hline FSP 20402 & 108900 & 9680144600 & Water & $09 / 17 / 96,09: 33$ & Tritiurn \\
\hline FSP 21302 & 108901 & 9680144800 & Water & $09 / 17 / 96,10: 22$ & Tritiurn \\
\hline FSP 22002 & 108905 & 9609541-05 & Water & $09 / 17 / 96,10: 52$ & Tritiurn \\
\hline FSP 22602 & 108902 & $9609541-03$ & Water & $09 / 17 / 96,10: 33$ & Tritiurn \\
\hline FSP 23502 & 108903 & 9609541-04 & Water & $09 / 17 / 96,10: 43$ & Tritiurn \\
\hline FSP 23502A & 108904 & 9609541-02 & Duplicate & $09 / 17 / 96,10: 44$ & Tritiurn \\
\hline FSP 24102 & 108968 & $9609541-48$ & Water & $09 / 24 / 96,13: 02$ & Tritiurn \\
\hline FSP 24902 & 108908 & $9609541-08$ & Water & 09/17/96, 13:11 & Tritiurn \\
\hline FSP 25602 & 108909 & $9609541-09$ & Water & 09/17/96, 13:22 & Tritiurn \\
\hline FSP 25602D & 108910 & 9680978000 & Split & $09 / 17 / 96,13: 25$ & Tritiurn \\
\hline FSP 27002 & 108907 & $9609541-07$ & Water & $09 / 17 / 96,12: 33$ & Tritium \\
\hline FSP 29002 & 108906 & $9609541-06$ & Water & $09 / 17 / 96,12: 21$ & Tritium \\
\hline HSP 0302 & 108923 & $9609541-17$ & Water & $09 / 18 / 96,13: 05$ & Tritiuun \\
\hline HSP 0402 & 108924 & $9609541-18$ & Water & $09 / 18 / 96,13: 10$ & Tritiun \\
\hline HSP 0802 & 108925 & $9609541-19$ & Water & $09 / 18 / 96,13: 25$ & Tritium \\
\hline HSP 1302 & 108926 & $9609541-20$ & Water & $09 / 18 / 96,13: 50$ & Tritium \\
\hline HSP 1502 & 108927 & $9609541-21$ & Water & $09 / 18 / 96,14: 00$ & Tritium \\
\hline HSP 2002 & 108928 & $9609541-22$ & Water & $09 / 18 / 96,14: 20$ & Tritium \\
\hline HSP 2502 & 108929 & $9609541-23$ & Water & 09/18/96, 14:30 & Tritium \\
\hline
\end{tabular}


Table 3.1. Sample Set, continued

\begin{tabular}{|l|l|l|l|l|l|}
\hline $\begin{array}{l}\text { Survey } \\
\text { Station ID }\end{array}$ & Sample ID & Laboratory ID & Sample Type & $\begin{array}{l}\text { Sample Date } \\
\text { and Time }\end{array}$ & $\begin{array}{l}\text { Analyses } \\
\text { Requested }\end{array}$ \\
\hline HSP 2902 & 108930 & $9609541-24$ & Water & $09 / 18 / 96,14: 40$ & Tritium \\
\hline HSP 4602 & 108936 & $9609541-27$ & Water & $09 / 19 / 96,09: 00$ & Tritium \\
\hline HSP 4902 & 108935 & $9609541-26$ & Water & $09 / 19 / 96,08: 50$ & Tritium \\
\hline HSP 5202 & 108934 & $9609541-25$ & Water & $09 / 19 / 96,08: 40$ & Tritium \\
\hline HSP 5202A & 108965 & $9609541-36$ & Duplicate & $09 / 19 / 96,08: 41$ & Tritium \\
\hline HSP 5702 & 108938 & $9609541-28$ & Water & $09 / 19 / 96,09: 40$ & Tritium \\
\hline HSP 6402 & 108939 & $9609541-29$ & Water & $09 / 19 / 96,10: 20$ & Tritium \\
\hline HSP 7102 & 108940 & $9609541-30$ & Water & $09 / 19 / 96,10: 30$ & Tritium \\
\hline HSP 7602 & 108941 & $9609541-31$ & Water & $09 / 19 / 96,10: 40$ & Tritium \\
\hline HSP 9702 & 108956 & $9609541-32$ & Water & $09 / 19 / 96,13: 50$ & Tritium \\
\hline HSP 9702A & 108957 & $9609541-33$ & Duplicate & $09 / 19 / 96,13: 52$ & Tritium \\
\hline HSP 10302 & 108955 & $9609541-34$ & Water & $09 / 19 / 96,13: 40$ & Tritium \\
\hline
\end{tabular}

\subsection{Field Data Quality Issues}

\section{3:2.1 Discrepancies from the Work Plan Assessment}

Ten samples listed in the work plan assessment could not be collected because the sample locations were dry, and there was insufficient volume to fill the sample bottles. A listing of the samples not collected is given in subsection 2.3.1, Discrepancies from the Work Plan Assessment.

Ten environmental samples and one duplicate sample that were originally planned for GE were sent to EMSL because they had high concentrations of tritium. For a complete list of these samples, see Table 2.3 of subsection 2.3.1, Discrepancies from the Work Plan Assessment.

\subsubsection{Sample Logbook Observations}

The split sample (FMC 2H01D) for sample FMC 2H01 was collected six days after the parent sample was collected.

\subsubsection{Chain-of-Custody Observations}

There were no COC observations that impacted data quality.

\subsection{Analytical Data Quality Issues}

\subsubsection{The Laboratories}

The water samples were analyzed by GE under contract AA07208N. GE has been certified by SCDHEC. EP, a subsidiary of GE, performed the analyses. Ten samples, one duplicate, and six split samples were analyzed by EMSL. 


\subsubsection{Laboratory Quality Control}

The laboratories follow their own QA/QC plans, which are designed to measure and document the accuracy and precision for the various sample control and analytical methods they perform. The laboratories are guided by published method-specific $\mathrm{QC}$ requirenents as well as other regulatory and contract-required QC procedures.

\subsubsection{List of Analytical Suites}

Tritium was the only analyte requested for all the samples for this project. See Appendix A for the methods used.

\subsubsection{Analytical Data Observations}

The data are final and complete except as noted in this subsection. Data validation is also complete.

Some of the data did not meet all the criteria listed in EPA, 1993, as noted below:

- Because the field measurements are not analyte specific, they are designed to meet the criteria for screening data, and definitive data criteria are not applicable.

- Analytical error determination (a measurement of method precision) was not calculated.

- No adjustments to sample values were made for bias or precision.

- Through the use of the criteria defined in EPA, 1993, matrix spike recoveries for an entire project are averaged, and all associated sample data are qualified on the basis of this average.

- Five of the nine matrix spikes could not be evaluated due to high concentrations of the analyte in the samples.

\subsection{Verification and Validation Issues}

\subsubsection{Analytical Narrative Review}

The EDDs and analytical narratives arrive from the laboratories and are logged in together. If the analytical narrative is missing, it is requested from the analytical laboratory. The narratives are reviewed and used as a reference throughout the data validation process. Discrepancies between the narratives and the analytical data must be resolved by the analytical laboratory. The analytical narratives contain summaries of the following problems encountered by the laboratory:

- QC samples that do not meet the criteria specified by the analytical method

- problems with matrix interference

- sample-specific adjustments to the method caused by high concentration of some analytes

- problems with sample holding time

- instrument calibration problems 
- contaminated blanks

- other laboratory QC issues

Additional information about the chain-of-custody data and analytical data is often found in the analytical narratives. Copies of the chain-of-custody forms attached to the analytical narratives are used for data review.

\subsubsection{Laboratory Data Records Review}

On November 11, 1996, laboratory data records were reviewed at EP for radiological analyses associated with this project. The review was conducted by Raymond M. Keller of ExR.

The purpose of the review was to investigate technical validation issues discussed in EPA, $1990 \mathrm{~b}$ that are not addressed adequately by computer checking of the EDDs, review of analytical narratives, or review of $\mathrm{COC}$ forms. These technical issues include instrument calibration, analyte identification, and analyte quantitation. The issues are addressed by comparing the instrument printouts associated with particular analyses against validation checklists. These checklists each consist of 13 questions and were prepared from six sources: EPA, 1986; EPA, 1988a; EPA, 1988b; EPA, 1990b; GE Standard Operating Procedures; and discussions with laboratory personnel.

For each analytical method, approximately $10 \%$ of the samples were chosen for review. Eleven LDRR forms for this project were completed. Each LDRR form represents one sample reviewed for one analytical method, (i.e., one sample/method combination [SMC]).

An inventory of the worksheets and methods reviewed is included in the following table.

Table 3.2. Laboratory Data Records Review Summary

\begin{tabular}{|l|l|l|l|}
\hline Analyte/Suite & Method & Checklist Used & Number of SMCs \\
\hline Tritium & EPA906.0 & Liquid Scintillation & 11 \\
\hline
\end{tabular}

\section{Scoring}

EPA906.0 Tritium

All LDRR checklist criteria were met in the 11 samples reviewed.

\section{Qualification of Analyses}

No qualification was necessary based upon the results of the LDRR.

\subsubsection{Qualification of the Data}

Each sample was evaluated on the following issues during validation:

- holding time

- sample preservation

- instrument calibration 
- analyte identification and quantitation

- trip blanks

- method blanks

- laboratory control samples/blank spikes

- rinsates, field blanks, and field duplicates

- laboratory duplicates

- matrix spikes

- surrogate recovery

- instrument readings

- internal standards

\section{Holding Time}

\section{Criteria}

Each analysis was evaluated according to the holding time limits for preparation (extraction or digestion) and analysis given in the following table.

Table 3.3. Holding Time Criteria

\begin{tabular}{|l|l|l|l|}
\hline Analytes & Reference & Extraction/Digestion & Analysis \\
\hline Cation exchange capacity & EPA, 1986 & NA & NA \\
\hline Cyanide & EPA, 1994a & NA & 14 days from collection \\
\hline Mercury & EPA, 1994a & NA & $\begin{array}{l}38 \text { days in glass or 13 days } \\
\text { in plastic from collection }\end{array}$ \\
\hline Metals & EPA, 1994a & NA & 6 months from collection \\
\hline Nitrate & EPA, 1994a & NA & 48 hours from collection \\
\hline Nitrogen (Kjeldahl method) & EPA, 1994a & NA & 28 days from collection \\
\hline Orthophosphate & EPA, 1994a & NA & 48 hours from collection \\
\hline Pesticide (soil) & EPA, 1994a & 14 days from collection & 40 days from extraction \\
\hline Pesticide (water) & EPA, 1994a & 7 days from collection & 40 days from ext!action \\
\hline Radionuclides & EPA, 1994a & NA & 180 days from collection \\
\hline Semivolatile organics (soil) & EPA, 1994a & 14 days from collection & 40 days from extraction \\
\hline $\begin{array}{l}\text { Semivolatile organics } \\
\text { (water) }\end{array}$ & EPA, 1994a & 7 days from collection & 40 days from extraction \\
\hline Sulfate & & & 28 days from collection \\
\hline Total phosphorus as P & EPA, 1994a & NA & 28 days from collection \\
\hline Volatile organics & EPA, 1994a & NA & 14 days from collection \\
\hline
\end{tabular}


Action

When holding times were exceeded, the following qualifiers were applied:

Analysis Qualifier: $Q$

Result Qualifier: $\quad J$-for detects $\quad U J$-for nondetects

Findings

All criteria were met for this project.

Discussion

Most methods specify limits on the time that can pass between sample collection and extraction or analysis. When holding times are exceeded, sample integrity may be compromised due to chemical and/or physical effects that can bias sample results either positively or negatively.

\section{Sample Preservation}

\section{Criteria}

Sample preservation requirements are determined by regulatory guidance, method specifications, and laboratory protocols. General requirements follow.

Soil

Inorganics: Inorganic analyses for metals require that soil samples be kept between $2^{\circ}$ and $6^{\circ} \mathrm{C}$.

Organics: Organic analyses for chlorinated hydrocarbons, haloethers, PCBs, pesticides, phenols, phthalate esters, purgeable aromatic hydrocarbons, purgeable halocarbons, tetrachlorodibenzo-p-dioxin isomers, and total organic carbon also require that soil samples be kept between $2^{\circ}$ and $6^{\circ} \mathrm{C}$. Soil samples to be analyzed for nitroaromatics and isophorone, nitrosamines, or polynuclear aromatic hydrocarbons must be stored in the dark at temperatures between $2^{\circ}$ and $6^{\circ} \mathrm{C}$.

Water

Inorganics: Water samples collected for metals analyses should have nitric acid added so that $\mathrm{pH}$ is less than 2 .

Organics: Water samples for all organic analyses should be kept between $2^{\circ}$ and $6^{\circ} \mathrm{C}$. Purgeable aromatic hydrocarbon analyses require that hydrochloric acid be added so that $\mathrm{pH}$ is less than 2, and total organic carbon analysis requires that hydrochloric acid or sulfuric acid be added so that $\mathrm{pH}$ is less than 2. Samples for nitroaromatics and isophorone must be stored in the dark. Samples for pesticides analyses should have $\mathrm{pH}$ adjusted to between 5 and 9 .

Soil and water samples for organic and inorganic analyses (excluding radiologicals and metals) must be shipped in coolers with temperatures of $4^{\circ} \mathrm{C} \pm 2^{\circ} \mathrm{C}$.

Action 
When cooler temperature requirements were not met, a $Y$ analysis qualifier was assigned.

Under the current contract, the laboratories do not report $\mathrm{pH}$ of samples requiring preservation. Thus, no assessment of the $\mathrm{pH}$ preservation criterion could be made.

\section{Findings}

All criteria were met for this project.

\section{Discussion}

Temperatures greater than the established limit may compromise the integrity and representativeness of the samples due to increased biological activity, hydrolysis of organic compounds, thermal degradation, and the loss of volatile and semivolatile compounds. The analytical results are expected to be biased low, and false negative results are possible.

False positive results also are possible due to the effects of biological and chemical degradation, and would most likely appear as TICs.

\section{Instrument Calibration}

\section{Criteria}

The calibration criteria specific to each method was used to evaluate instrument calibration during the LDRR.

Action

When calibration criteria were not met, the following qualifiers were assigned:

Analysis Qualifier: $L$

Result Qualifiers: $\quad J$ or $R$-detects $\quad U J$-for nondetects

\section{Findings}

All criteria were met for this project.

Discussion

Instrument calibration ensures that the instrument is capable of producing acceptable quantitative results. Initial calibration demonstrates that the instrument is capable of acceptable performance at the beginning of the analysis run, and continuing calibration verification documents that the initial calibration is still valid. After initial calibration, a continuing calibration standard and blank should be analyzed after every ten samples.

\section{Analyte Identification and Quantitation}

This issue was examined during the LDRR. The findings are presented in subsection 3.4.2, Laboratory Data Records Review. 


\section{Trip Blanks}

\section{Criteria}

Trip blanks were used to determine the existence and magnitude of contamination from shipping activities. Only data for the volatile organic fraction were evaluated based on trip blank results, and the CLP $5 \times / 10 \times$ rule was used for data qualification.

\section{Action}

When an analyte is detected in a trip blank, an analysis qualifier is assigned to that analyte in the blank and to all samples that are shipped in the same cooler as the trip blank having positive results. If the analyte concentration in a sample is less than five times that in the blank (less than 10 times for the common laboratory contaminants acetone, dichloromethane [methylene chloride], and methyl ethyl ketone), assign a result qualifier to that analyte in the sample.

Analysis Qualifier: 8

Result Qualifier: $\quad U$

\section{Findings}

Trip blanks were not applicable for this project.

\section{Discussion}

Volatile organic contamination can be introduced into a trip blank in three ways: during blank preparation at the laboratory; during storage of the trip blank in the cooler; or by cross-contamination from other samples. The contamination can cause false positives in the trip blank and in the samples exposed to contamination.

\section{Method Blanks}

\section{Criteria}

Method blanks are used to determine the existence and magnitude of contamination from laboratory activities. Method blanks with analytical results greater than zero are considered to be contaminated. The CLP $5 \times / 10 \times$ rule is used for data qualification.

\section{Action}

When an analyte is detected in a method blank, an analysis qualifier is assigned to that analyte in the blank and to every sample of the preparation batch having positive results. If the analyte concentration in a sample is less than five times that in the blank (less than 10 times for common laboratory contaminants), assign a result qualifier to that analyte in the sample. A bias qualifier should be used only if the laboratory believes the sample is contaminated and has assigned the qualifier.

The following qualifiers may be assigned:

Analysis Qualifier: $V$

Result Qualifier: $\quad U$ 
Bias Qualifier: $\quad H$

Findings

No qualification was performed based on method blanks.

\section{Laboratory Control Samples}

\section{Criteria}

- Dioxins/furans: $40-120 \%$ recovery (EPA, 1986)

- Inorganics: 80-120\% recovery except EPA6020 and EPA6020A, which have 70-130\% recovery

- Pesticides: Page D-61 PEST (EPA, 1991b)

- Radiologicals: $80-120 \%$ (WHC, not dated)

- Semivolatiles: Table 7, page D-59 SVA (EPA, 1991b)

- Volatiles: Table 7, page D-55 VOA (EPA, 1991b)

\section{Action}

When the percent recovery for an analyte in the LCS was outside the QC limits, that analyte in the LCS was qualified with an analysis qualifier. That analyte in each sample of the preparation batch also was qualified. If an LCS was not included in the preparation batch, all spike compounds for the associated samples were qualified with an analysis and a result qualifier.

LCS recovery below lower QC limit:

Analysis Qualifier: $C$

Result Qualifiers: $J$-for detects $\quad U J$-for nondetects

LCS recovery above upper QC limit:

Analysis Qualifier: $\quad C$

Result Qualifiers: J-for detects

Findings

All LCS criteria were met for this project.

Discussion

LCS percent recoveries that exceed the upper QC limit could indicate a high bias for samples with positive results. Percent recoveries that are less than the lower QC limit could indicate a low bias for samples with positive results, and nondetect results should be considered questionable. 
Rinsates, Field Blanks, and Field Duplicates

No qualification is performed based on rinsates, field blanks, and field duplicates.

\section{Laboratory Duplicates}

\section{Criteria}

- Radiologicals: (WHC, not dated)

The RPD of a sample and its associated laboratory duplicate must be $20 \%$ or less for water samples and $35 \%$ or less for soil samples. These method-required limits do not apply to results reported at levels less than five times the detection limit. For results less than five times the detection limit, water samples must have RPDs less than $100 \%$ and soil samples must have RPDs less than $200 \%$.

\section{Action}

For soil samples, when duplicate analysis results for a particular analyte fall outside the $\mathrm{QC}$ limits for the RPD, that analyte in the parent and duplicate samples was qualified.

Analysis Qualifier: $X$

For water samples, when the RPD for a particular analyte was outside the appropriate QC limits, analysis qualifiers were assigned to that analyte in the parent and duplicate samples and to that analyte in every sample in the same preparation batch.

Analysis Qualifier: $X$

Result Qualifiers: $J$-for detects $\quad U J$-for nondetects

\section{Findings}

No qualification was performed based on laboratory duplicates.

\section{Matrix Spikes}

\section{Criteria}

- Inorganics: Page 11 (EPA, 1988a)

\section{Action}

1. When an MS did not meet criteria, qualifiers were added only to the failed analyte in the MS and the failed analyte in the samples associated with the MS. Only the MS and parent sample records were qualified for soil samples. The MS, the parent sample, and all the samples in the same preparation batch were qualified for water samples. The data were qualified as follows:

Analysis Qualifier: $I$

Result Qualifiers: J-for detects $\quad U J$-for nondetects

Bias Qualifiers: $\quad H$-if all MS recoveries were above QC limits 
$L$-if all MS recoveries were below QC limits

2. MS recovery limits do not apply when the spike concentration is less than $25 \%$ of the sample concentration. When this occurred, the MS record only was qualified as follows:

Analysis Qualifier: 5

Result Qualifier: $\quad R$

3. If the laboratory believed poor recoveries were due to matrix interferences, the MSs record was not used for qualification of any associated data. The MS record was qualified as follows:

\section{Analysis Qualifier: 4}

Result Qualifier: $\quad R$

4. If the laboratory did not perform matrix spikes for nonradiological analyses, the following qualifier was used:

Analysis Qualifier: I

\section{Findings}

None of the environmental sample records were qualified. Only the matrix spike records were qualified. The following table lists matrix spike analyses were rejected.

Table 3.4. Matrix Spikes Rejected due to High Concentration of the Analyte in the Sample by EP

\begin{tabular}{|l|l|}
\hline Analyte & Frequency Rejected \\
\hline Radionuclides & \\
\hline Tritium & $5 / 6$ \\
\hline
\end{tabular}

\section{Discussion}

When the matrix spike percent recovery for an analyte is high, the results for associated data may be biased positively. When the matrix spike percent recovery for an analyte is low, the results for associated data may be biased negatively, and the nondetected results should be considered questionable.

\section{Surrogate Recovery}

\section{Criteria}

- Pesticides by Method 8080: 60-150\%, page D-56 PEST (EPA, 1991b)

- Semivolatiles by Method 8270: Table 8, page 8270-31 (EPA, 1986)

- Volatiles by Method 8240: Table 8, page 8240-38 (EPA, 1986)

- Volatiles by Method 8260: Table 9, page 8260-44 (EPA, 1986) 


\section{Action}

Volatiles and/or pesticides: When one or more surrogates failed QC criteria, all volatile and/or pesticide analytes in the sample were qualified as follows:

Analysis Qualifier: $O$

Result Qualifiers: J-for detects $\quad U J$-for nondetects

Bias Qualifiers: $\quad H$-if all failed surrogates have high recoveries

$L$-if all failed surrogates have low recoveries

When one surrogate was high and another was low, a bias qualifier was not assigned, and the $O$ analysis qualifier was assigned to the failed surrogates.

Semivolatiles: When only one surrogate failed and its recovery was $>10 \%$, no action was taken. When more than one surrogate failed QC criteria, all semivolatile analytes in the sample were qualified as follows:

Analysis Qualifier: $O$

Result Qualifiers: J-for detects $\quad U J$-for nondetects

Bias Qualifiers: $\quad H$-if all failed surrogates have high recoveries

$L$-if all failed surrogates have low recoveries

When one surrogate was high and another was low, a bias qualifier was not assigned, and the $O$ analysis qualifier was assigned to the failed surrogates.

\section{Findings}

Surrogates were not applicable for this project.

Discussion

When the surrogate percent recovery is high, the results for associated data may be biased positively. When the surrogate percent recovery is low, the results for associated data may be biased negatively, and the nondetected results should be considered questionable.

\section{Instrument Readings}

\section{Criteria}

For radiologicals, nondetected parameters reported from an instrument reading required a result qualifier.

\section{Action}

The result qualifier was as follows:

Result Qualifier: $\quad U I$-for nondetects 


\section{Findings}

One of 129 environmental sample records was qualified.

Discussion

For radiological analyses, the laboratory's instrumentation and data management software calculate the MDA, result, and accuracy. If the reported result was less than the MDA and/or the accuracy, a $U I$ result qualifier was assigned.

\section{Internal Standards}

\section{Criteria}

- Semivolatiles by Method 8270: Table 5, page 8270-20 or 8270A-35 (EPA, 1986)

- Volatiles by Method 8240: Table 5, page 8240A-33 (EPA, 1986)

- Volatiles by Method 8260: Table 6, page 8260-39 (EPA, 1986)

This requirement was evaluated during the LDRR.

\section{Action}

When the internal standard recovery varied more than the factor of two $(-50 \%$ to $+100 \%)$ from the associated calibration standard, all analytes quantified using the internal standard were qualified as follows:

Analysis Qualifier: $H$

Result Qualifiers: $\quad J$-for detects $\quad U J$-for nondetects

No qualifier is used for nondetects with internal standards greater than the QC limits.

Findings

Internal standards were not applicable to this project.

Discussion

When the internal standard recovery is high, the associated data may be biased positively. When the internal standard recovery is low, the associated data may be biased negatively, and all nondetected results should be considered questionable.

\subsection{Precision and Accuracy}

This section discusses the analytical data in terms of the precision and accuracy indicators of data quality. Precision is determined from the field and laboratory duplicate analyses and indicates the consistency of field and laboratory techniques. Accuracy is determined from the laboratory control samples and blank spikes, matrix spikes, and the results of the method, field, trip, and equipment blanks or rinsates and indicates the ability of the laboratory to generate correct results. 


\subsubsection{Precision}

Precision is a measure of the repeatability of a measurement and is evaluated from the results of field and laboratory duplicate samples. Field duplicates measure the repeatability for the sampling and analytical techniques, and laboratory duplicates measure the ability of the laboratory to reproduce a result. Low precision can be caused by poor instrument performance, poor operator technique, inconsistent application of method protocols, laboratory environment, time between analyses, or a difficult, heterogeneous sample matrix. Precision is especially important when the action limit approaches the quantitation limit. At least $5 \%$ of the samples are collected in duplicate. The laboratory performs duplicate analyses on at least $10 \%$ of the samples received.

Precision is expressed in terms of the relative percent difference as follows:

$$
\mathrm{RPD}=\frac{|x-y|}{\left(\frac{x+y}{2}\right)} \times 100
$$

where $x$ is the original sample result and $y$ is the duplicate sample result. When one result of a duplicate pair is below the MDA, the ssEQL is used for that result in the calculation. When both results are below the MDA, the RPD cannot be calculated.

The RPD should be less than $20 \%$ for water samples and less than $35 \%$ for soil samples when results are above the ssEQL. In the case where results are between the ssEQL and the MDA, the RPD should be less than $100 \%$ for water samples and less than $200 \%$ for soil samples.

The RPDs for the laboratory and field duplicates are listed in the following tables. The frequency out-of-range column is the number of duplicates that had RPDs greater than the acceptance limit compared to the total number analyzed; the other columns provide the * mean RPD, standard deviation, and the minimum and maximum RPDs.

Table 3.5. Relative Percent Differences of Laboratory Duplicates by EP

\begin{tabular}{|l|l|l|l|l|l|}
\hline & $\begin{array}{l}\text { Frequency } \\
\text { Out of } \\
\text { Range }\end{array}$ & $\begin{array}{l}\text { Mean } \\
\text { RPD (\%) }\end{array}$ & $\begin{array}{l}\text { Std. } \\
\text { Dev. }\end{array}$ & $\begin{array}{l}\text { Minimum } \\
\text { RPD (\%) }\end{array}$ & $\begin{array}{l}\text { Maximum } \\
\text { RPD (\%) }\end{array}$ \\
\hline Radionuclides & $0 / 6$ & 2.32 & 2.75 & 0 & 6.97 \\
\hline Tritium & 0
\end{tabular}

Table 3.6. Relative Percent Differences of Field Duplicates by EMSL

\begin{tabular}{|l|l|l|l|l|l|}
\hline & $\begin{array}{l}\text { Frequency } \\
\text { Out of } \\
\text { Range }\end{array}$ & $\begin{array}{l}\text { Mean } \\
\text { RPD (\%) }\end{array}$ & $\begin{array}{l}\text { Std. } \\
\text { Dev. }\end{array}$ & $\begin{array}{l}\text { Minimum } \\
\text { RPD (\%) }\end{array}$ & $\begin{array}{l}\text { Maximum } \\
\text { RPD (\%) }\end{array}$ \\
\hline Radionuclides & $0 / 3$ & 1.35 & 1.27 & 0.3 & 2.76 \\
\hline Tritium
\end{tabular}


Table 3.7. Relative Percent Differences of Field Duplicates by EP

\begin{tabular}{|l|l|l|l|l|l|}
\hline & $\begin{array}{l}\text { Frequency } \\
\text { Out of } \\
\text { Range }\end{array}$ & $\begin{array}{l}\text { Mean } \\
\text { RPD (\%) }\end{array}$ & $\begin{array}{l}\text { Std. } \\
\text { Dev. }\end{array}$ & $\begin{array}{l}\text { Minimum } \\
\text { RPD (\%) }\end{array}$ & $\begin{array}{l}\text { Maxirnum } \\
\text { RPD (\%) }\end{array}$ \\
\hline Radionuclides & $1 / 5$ & 30.4 & 65.7 & 0.163 & 148 \\
\hline Tritium
\end{tabular}

\subsubsection{Accuracy}

Accuracy is defined as the closeness of agreement between an observed value and an accepted reference value. Accuracy is especially important when the concentration of concern approaches the quantitation limit and/or the action limit. When the concentration is underestimated near the quantitation limit, the analyte may be present but reported as not detected. When the concentration is underestimated near the action limit, the analyte may be at a concentration that would require remediation, but the remediation would not be performed. When the concentration is overestimated near the quantitation limit, the analyte may not be present but reported as detected. When the concentration is overestimated near the action limit, the analyte may not be at a concentration that would require remediation, but the remediation would be performed. The sample types used to evaluate accuracy are performance evaluation studies, LCS/BSs, surrogate spikes, and matrix spikes.

\section{Laboratory Control Samples}

LCSs monitor the performance of all steps in the analysis process, including sample preparation, and are used to identify problems with the analytical procedure. LCSs for inorganic analyses are DI water that is spiked with the target analyte, digested, and analyzed with the regular samples. LCSs for organic analyses are DI water that is spiked with selected target analytes, extracted, and analyzed with the regular samples. The LCS spiking solutions or solid LCSs are obtained from EPA, a third-party supplier, or are prepared in the laboratory from chemicals from a different source than the calibration standards. The following table lists the $\mathrm{QC}$ limits for each analyte.

Table 3.8. EPA Quality Control Limits for Laboratory Control Samples

\begin{tabular}{|l|l|l|}
\hline Analyte & Aqueous Samples (\%) & Soil Samples (\%) \\
\hline Radionuclides $^{1}$ & $80-120$ & $80-120$ \\
\hline
\end{tabular}

The following tables list the statistical information for the percent recovery for LCSs by analyte. The frequency out-of-range column is the number of LCSs that had percent recoveries outside the acceptance limits compared to the total number analyzed; the other columns provide the mean percent recovery, standard deviation, and the minimum and maximum percent recoveries.

I (WHC, not dated)

Fourmile Branch and the F- and H-Area Seeplines, Tritium 
The percent recovery is calculated as

$$
\% R=\frac{S R}{S A} \times 100,
$$

where $\% \mathrm{R}=$ percent recovery

$$
\begin{aligned}
& \mathrm{SR}=\mathrm{LCS} \text { sample result } \\
& \mathrm{SA}=\text { spike-added result }
\end{aligned}
$$

Table 3.9. Laboratory Control Sample Recoveries by EMSL

\begin{tabular}{|l|l|l|l|l|l|}
\hline & $\begin{array}{l}\text { Frequency } \\
\text { Out of } \\
\text { Range }\end{array}$ & $\begin{array}{l}\text { Mean } \\
\text { Recovery } \\
(\%)\end{array}$ & $\begin{array}{l}\text { Std. } \\
\text { Dev. }\end{array}$ & $\begin{array}{l}\text { Minimum } \\
\text { Recovery } \\
(\%)\end{array}$ & $\begin{array}{l}\text { Maximum } \\
\text { Recovery } \\
(\%)\end{array}$ \\
\hline Radionuclides & $0 / 7$ & 89.6 & 3.97 & 85 & 93.5 \\
\hline Tritium
\end{tabular}

Table 3.10. Laboratory Control Sample Recoveries by EP

\begin{tabular}{|l|l|l|l|l|l|}
\hline & $\begin{array}{l}\text { Frequency } \\
\text { Out of } \\
\text { Range }\end{array}$ & $\begin{array}{l}\text { Mean } \\
\text { Recovery } \\
(\%)\end{array}$ & $\begin{array}{l}\text { Std. } \\
\text { Dev. }\end{array}$ & $\begin{array}{l}\text { Minimum } \\
\text { Recovery } \\
(\%)\end{array}$ & $\begin{array}{l}\text { Maximum } \\
\text { Recovery } \\
(\%)\end{array}$ \\
\hline Radionuclides & $0 / 7$ & 98.2 & 1.82 & 95.9 & 101 \\
\hline Tritium & 0
\end{tabular}

\section{Matrix Spikes}

Matrix spikes are used to evaluate the effect of the sample matrix on the analytical procedure. Matrix spikes for at least $5 \%$ of the samples are prepared by adding a known quantity of the target analyte to the samples prior to sample preparation. For the inorganic analyses, all target analytes are spiked. For the organic analyses, selected target analytes are used in the spiking solution. Results from the matrix spikes are used to evaluate the extent of matrix interference.

The QC limits for matrix spikes are the same as those for LCS/BSs given in Table 3.8, except for inorganics, which have limits of $75-125 \%$. Matrix spikes are rejected if the concentration of the analyte in the samples is more than four times the amount of the spike.

The following tables list the percent recovery for the matrix spikes. The frequency-out-of range column is the number of matrix spikes that had percent recoveries outside the acceptance limits compared to the total number analyzed; the other columns provide the mean percent recovery, standard deviation, and the minimum and maximum percent recoveries. 
Table 3.11. Matrix Spike Recoveries by EMSL

\begin{tabular}{|l|l|l|l|l|l|}
\hline & $\begin{array}{l}\text { Frequency } \\
\text { Out of } \\
\text { Range }\end{array}$ & $\begin{array}{l}\text { Mean } \\
\text { Recovery } \\
(\%)\end{array}$ & $\begin{array}{l}\text { Std. } \\
\text { Dev. }\end{array}$ & $\begin{array}{l}\text { Minimum } \\
\text { Recovery } \\
(\%)\end{array}$ & $\begin{array}{l}\text { Maximum } \\
\text { Recovery } \\
(\%)\end{array}$ \\
\hline Radionuclides & $0 / 3$ & 90.7 & 3.58 & 86.7 & 93.6 \\
\hline Tritium
\end{tabular}

Table 3.12. Matrix Spike Recoveries by EP

\begin{tabular}{|l|l|l|l|l|l|}
\hline & $\begin{array}{l}\text { Frequency } \\
\text { Out of } \\
\text { Range }\end{array}$ & $\begin{array}{l}\text { Mean } \\
\text { Recovery } \\
(\%)\end{array}$ & $\begin{array}{l}\text { Std. } \\
\text { Dev. }\end{array}$ & $\begin{array}{l}\text { Minimum } \\
\text { Recovery } \\
(\%)\end{array}$ & $\begin{array}{l}\text { Maximum } \\
\text { Recovery } \\
(\%)\end{array}$ \\
\hline Radionuclides & $0 / 1$ & 98.8 & & 98.8 & 98.8 \\
\hline Tritium & $0 / 1$ \\
\hline
\end{tabular}

\subsubsection{Contamination in Quality Control Samples}

\section{Method Blanks}

Method blanks are used to determine the existence and magnitude of contamination resulting from the analytical process. Method blanks are analyte-free matrices, DI vater for aqueous samples and sodium sulfate for solid samples, which are prepared in the same manner and at the same time as the samples. When method blanks have detectable concentrations of analytes, the laboratory must determine the cause and take corrective action to eliminate the contamination.

The following tables list the statistical information for the method blanks. The frequency detected column gives the number of method blanks analyzed for each analyte that had detectable concentrations compared to the total number analyzed. The other columris list the mean result, standard deviation, minimum and maximum results, and reporting unit.

Table 3.13. Analytes Detected in Method Blanks by EMSL

\begin{tabular}{|l|l|l|l|l|l|}
\hline Analyte & $\begin{array}{l}\text { Frequency } \\
\text { Detected }\end{array}$ & $\begin{array}{l}\text { Mean } \\
\text { Result }\end{array}$ & Std. Dev. & $\begin{array}{l}\text { Min.Max. } \\
\text { Result }\end{array}$ & Unit \\
\hline Radionuclides & \multicolumn{5}{|l|}{} \\
\hline Tritium & $0 / 7$ & $4.29 \mathrm{E}-10$ & $1.13 \mathrm{E}-7$ & $-1.97 \mathrm{E}-7 / 1.83 \mathrm{E}-7$ & $\mathrm{pCi} / \mathrm{mL}$ \\
\hline
\end{tabular}


Table 3.14. Analytes Detected in Method Blanks by EP

\begin{tabular}{|l|l|l|l|l|l|}
\hline & $\begin{array}{l}\text { Frequency } \\
\text { Detected }\end{array}$ & $\begin{array}{l}\text { Mean } \\
\text { Result }\end{array}$ & Std. Dev. & $\begin{array}{l}\text { Min./Max. } \\
\text { Result }\end{array}$ & Unit \\
\hline Radionuclides & $0 / 7$ & -0.0282 & 0.146 & $-0.279 / 0.203$ & $\mathrm{pCi} / \mathrm{mL}$ \\
\hline Tritium
\end{tabular}

\subsubsection{Comparability}

The comparability of the data from the laboratories is based on the results of the split samples. For at least $10 \%$ of the sample locations, a split sample is collected and sent to the designated QC laboratory. The following table lists the RPDs, sample IDs, results that are greater than the minimum detectable activity for each analyte, and reporting units.

Table 3.15. Split Sample Results

\begin{tabular}{|c|c|c|c|c|c|c|}
\hline \multirow[b]{2}{*}{ Analyte } & \multirow[b]{2}{*}{ RPD } & \multicolumn{2}{|c|}{ EP } & \multicolumn{2}{|c|}{ EMSL } & \multirow[b]{2}{*}{ Unit } \\
\hline & & $\begin{array}{l}\text { Sample } \\
\text { ID }\end{array}$ & Result & $\begin{array}{l}\text { Sample } \\
\text { ID }\end{array}$ & Result & \\
\hline Tritium & 1.47 & 106560 & 541 & 106561 & 549 & $\mathrm{pCi} / \mathrm{mL}$ \\
\hline Tritium & 1.74 & 108909 & 285 & 108910 & 290 & $\mathrm{pCi} / \mathrm{mL}$ \\
\hline Tritium & 0.473 & 108958 & 211 & 108959 & 212 & $\mathrm{pCi} / \mathrm{mL}$ \\
\hline Tritium & 15.6 & 108963 & 75.5 & 108966 & 88.3 & $\mathrm{pCi} / \mathrm{mL}$ \\
\hline
\end{tabular}


This page was left blank intentionally. 


\subsection{References}

DOE (U.S. Department of Energy), 1992. Environmental Measurements Laboratory Procedures Manual, HASL-300, 27th edition. Environmental Measurements Laboratory, New York, NY.

EPA (U.S. Environmental Protection Agency), 1983. Methods for Chemical Analysis of Water and Wastes, EPA-600/4-79-020. Environmental Monitoring and Support Laboratory, Cincinnati, $\mathrm{OH}$.

EPA (U.S. Environmental Protection Agency), 1986. Test Methods for Evaluating Solid Waste (SW-846), Volume I, including updates. Office of Solid Waste, Washington, DC.

EPA (U.S. Environmental Protection Agency), 1987. Data Quality Objectives for Remedial Response Activities: Development Process, EPA 540/G-87/003. Washington, DC.

EPA (U.S. Environmental Protection Agency), 1988a. Laboratory Data Validation Functional Guidelines for Evaluating Inorganics Analyses. Hazardous Site Evaluation Division, Washington, DC.

EPA (U.S. Environmental Protection Agency), 1988b. Laboratory Data Validation Functional Guidelines for Evaluating Organics Analyses. Hazardous Site Evaluation Division, Washington, DC.

EPA (U.S. Environmental Protection Agency), 1990a. Quality Assurance/Quality Control Guidance for Removal Activities, Sampling QAVC Plan and Data Validation Procedures, EPA 540/G-90/004. Washington, DC.

EPA (U.S. Environmental Protection Agency), 1990b. Guidance for Data Usability in Risk Assessment, EPA/540/G-90/008. Office of Emergency and Remedial Response, Washington, DC.

EPA (U.S. Environmental Protection Agency), 1991a. U.S. EPA Contract Laboratory Program, Statement of Work (CLP SOW) for Organics Analysis, Multi-Media, Multi-Concentration, OLM01.0. Washington, DC.

EPA (U.S. Environmental Protection Agency), 1991b. U.S. EPA Contract Laboratory Program, Statement of Work (CLP SOW) for Inorganics Analysis, Multi-Media, Multi-Concentration, ILM03.0. Washington, DC.

EPA (U.S. Environmental Protection Agency), 1991c. Test Method: The Determination of Inorganic Anions in Water by Ion Chromatography-Method 300.0.

Environmental Monitoring and Systems Laboratory, Cincinnati, $\mathrm{OH}$.

EPA (U.S. Environmental Protection Agency), 1993. Data Quality Objectives Process for Superfund, EPA 540/R-93/071. Washington, DC. 
EPA (U.S. Environmental Protection Agency), 1994a. Guidelines Establishing Test Procedures for the Analysis of Pollutants, Code of Federal Regulations, Title 40, Part 136. Washington, DC.

EPA (U.S. Environmental Protection Agency), 1994b. Identification and Listing of Hazardous Waste, Code of Federal Regulations, Title 40, Part 261. Washington, DC.

EPA (U.S. Environmental Protection Agency), 1994c. Requirements for Authorization of State Hazardous Waste Programs, Code of Federal Regulations, Title 40, Part 271. Washington, DC.

EPD/EMS (Environmental Protection Department/Environmental Monitoring Section), 1995. AN95 Format, January 1, 1995. Westinghouse Savannah River Company, Savannah River Site, Aiken, SC.

WSRC (Westinghouse Savannah River Company), 1992b. Soil Boring Investigations, Hydrogeologic Data Collection Procedures and Specifications, Manual 3Q5, Rev. 1, Chapter 6. Savannah River Site, Aiken, SC.

WSRC (Westinghouse Savannah River Company), 1992c. Sampling Groundwater Monitoring Wells, Hydrogeologic Data Collection and Specifications, Manual 3Q5, Rev. 1, Chapter 15. Savannah River Site, Aiken, SC.

WSRC (Westinghouse Savannah River Company), 1992d. Sampling Soils for Analytical Purposes, Hydrogeologic Data Collection Procedures and Specifications, Manual 3Q5, Rev. 1, Chapter 16. Savannah River Site, Aiken, SC.

WSRC (Westinghouse Savannah River Company), 1992e. Approved Analytical Procedures, Hydrogeologic Data Collection Procedures and Specifications, Manual 3Q5, Rev. 1, Chapter 17. Savannah River Site, Aiken, SC.

WSRC (Westinghouse Savannah River Company), 1992f. Results of the First Quarter Tritium Survey of the $F$ and $H$ Area Seeplines: May 1992, WSRC-TR-92-304, June, 1992. Savannah River Site, Aiken, SC.

WSRC (Westinghouse Savannah River Company), 1995. Draft Semi-Annual Sampling of Fourmile Branch and Its Seeplines in the F and HAreas of SRS: February 1993, July 1993, and April 1994, WSRC-TR-94-0454, Rev. 1, November 3, 1995.

Savannah River Site, Aiken, SC. 


\section{Appendix A: Analytical Methods and Minimum Detectable Activity}

In the following tables of analytical methods and minimum detectable activity, the MDA column reports the lowest concentration that can reliably be achieved within specified limits for precision and accuracy during routine laboratory operating conditions. The Reference column provides the published source for the method, with the exception of the analyses that are performed by the laboratories' established methods.

Table A.1. Water Analytical Method and Minimum Detectable Activity for EP

\begin{tabular}{|l|l|l|l|l|}
\hline Analyte & Method & Unit & MDA & Reference \\
\hline Radionuclides & EPA906.0 & pCi/mL & NA & EP \\
\hline Tritium
\end{tabular}

Table A.2. Water Analytical Method and Minimum Detectable Activity for EMSL

\begin{tabular}{|l|l|l|l|l|}
\hline Analyte & Method & Unit & MDA & Reference \\
\hline Radionuclides & $3 Q 1-6-1420$ & pCi/mL & NA & EMSL \\
\hline Tritium
\end{tabular}

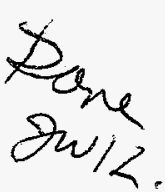




\section{Appendix B: Laboratory Performance Evaluation Results}

No performance evaluation results for tritium are available for the EP or EMSL. 


\section{Appendix C: Formats of the Data Files}

When entering data in any of the formats, the following conventions are to be used.

- Alpha and alphanumeric entries must be left justified in the records.

- Numeric entries must be right justified in the records.

- There will be no leading zeros except in dates and times.

The following table describes the sample data format, SAM93, which is used for coding and transmitting sampling data records. The formats presented in this appendix have been established by WSRC-EPD/EMS.

Table C.1. Sample Data Format SAM93

\begin{tabular}{|c|c|c|c|}
\hline Name & Columns & Type & Description \\
\hline Record format & $1-8$ & Alphanumeric & SAM93 (the format of the data record) \\
\hline $\begin{array}{l}\text { Sample } \\
\text { identification } \\
\text { number }\end{array}$ & $9-14$ & Integer & $\begin{array}{l}\text { The number of the sample printed on the } \\
\text { page of the sample logbook }\end{array}$ \\
\hline $\begin{array}{l}\text { Sample collection } \\
\text { date }\end{array}$ & $15-20$ & Numeric & $\begin{array}{l}\text { Sample collection date recorded using the } \\
\text { MMDDYY format }\end{array}$ \\
\hline $\begin{array}{l}\text { Sample collection } \\
\text { time }\end{array}$ & $21-24$ & Integer & $\begin{array}{l}\text { Sample collection time recorded as military } \\
\text { time }\end{array}$ \\
\hline Sample type & 25 & Numeric & $\begin{array}{l}\text { Sample type coded as } \\
1=\text { normal } \\
2=\text { trip blank } \\
3=\text { field blank } \\
4=\text { split } \\
5=\text { rinsate } \\
6=\text { duplicate } \\
7=\text { other }\end{array}$ \\
\hline Sample matrix & 26 & Numeric & $\begin{array}{l}\text { Sample matrix coded as } \\
1=\text { soil } \\
2=\text { rock } \\
3=\text { sludge } \\
4=\text { water } \\
5=\text { sediment } \\
6=\text { other }\end{array}$ \\
\hline Delay check & 27 & Alpha & $\begin{array}{l}\text { Enter a } Y \text { if there was an unusual delay in } \\
\text { bottling samples }\end{array}$ \\
\hline Sampler's initials & $28-30$ & Alpha & Sampler's initials \\
\hline
\end{tabular}


Table C.1. Sample Data Format SAM93, continued

\begin{tabular}{|c|c|c|c|}
\hline Name & Columns & Type & Description \\
\hline Associated sample & $31-36$ & Integer & $\begin{array}{l}\text { Sample identification of associated sample } \\
\text { if this sample is a duplicate, split, rinsate, } \\
\text { etc. }\end{array}$ \\
\hline $\begin{array}{l}\text { Planned sample } \\
\text { name }\end{array}$ & $37-46$ & Alphanumeric & $\begin{array}{l}\text { Identification of the sample as it appears in } \\
\text { the site work plan }\end{array}$ \\
\hline Sample name & $47-56$ & Alphanumeric & $\begin{array}{l}\text { Identification of the actual sample (includes } \\
\text { any modification made in the field) }\end{array}$ \\
\hline $\begin{array}{l}\text { Planned top of } \\
\text { interval }\end{array}$ & $57-62$ & Numeric & $\begin{array}{l}\text { Depth from the ground to the top of the } \\
\text { planned sampling interval to the nearest } \\
0.01 \mathrm{ft}\end{array}$ \\
\hline Top of interval & $63-68$ & Numeric & $\begin{array}{l}\text { Depth from the ground to the top of the } \\
\text { actual sampling interval to the nearest } 0.01 \\
\mathrm{ft}\end{array}$ \\
\hline $\begin{array}{l}\text { Planned bottom of } \\
\text { interval }\end{array}$ & $69-74$ & Numeric & $\begin{array}{l}\text { Depth from the ground to the bottom of the } \\
\text { planned sampling interval to the nearest } \\
0.01 \mathrm{ft}\end{array}$ \\
\hline Bottom of interval & $75-80$ & Numeric & $\begin{array}{l}\text { Depth from the ground to the bottom of the } \\
\text { actual sampling interval to the nearest } 0.01 \\
\text { ft }\end{array}$ \\
\hline Soil moisturel & 81 & Numeric & $\begin{array}{l}\text { Soil moisture coded as: } \\
1=\text { dry } \\
2=\text { damp } \\
3=\text { wet } \\
4=\text { sludge } \\
5=\text { liquid }\end{array}$ \\
\hline Munsell color ${ }^{1}$ & $82-91$ & Alphanumeric & Munsell color \\
\hline Soil classification ${ }^{1}$ & 92-93 & Alphanumeric & Unified Soil Classification \\
\hline Number of bottles & 94-96 & Integer & $\begin{array}{l}\text { The number of bottle label numbers used } \\
\text { during collection }\end{array}$ \\
\hline $\begin{array}{l}\text { Insufficient } \\
\text { recovery check }\end{array}$ & 97 & Alpha & \begin{tabular}{|l|} 
Enter an $R$ if insufficient material was \\
recovered to perform all analyses \\
\end{tabular} \\
\hline $\begin{array}{l}\text { Improper } \\
\text { procedure check }\end{array}$ & 98 & Alpha & $\begin{array}{l}\text { Enter a } P \text { if an improper sampling } \\
\text { procedure was followed }\end{array}$ \\
\hline
\end{tabular}

${ }^{1}$ No data are reported for this field. 
This is the description of the sample bottle data format, SAM93A, which is used for coding and transmitting sample bottle data records.

Table C.2. Sample Bottle Data Format SAM93A

\begin{tabular}{|l|l|l|l|}
\hline Name & Columns & Type & Description \\
\hline Record format & $1-8$ & Alphanumeric & SAM93A (the format of the data record) \\
\hline $\begin{array}{l}\text { Sample identification } \\
\text { number }\end{array}$ & $9-14$ & Integer & $\begin{array}{l}\text { The number of the sample printed on } \\
\text { the page of the sample logbook }\end{array}$ \\
\hline Bottle label number & $15-23$ & Integer & $\begin{array}{l}\text { The number of the bottle label attached } \\
\text { to the bottle }\end{array}$ \\
\hline
\end{tabular}

This is the description of the survey station data format, STA93, which is used for coding and transmitting station data records.

Table C.3. Survey Station Data Format STA93

\begin{tabular}{|l|l|l|l|}
\hline Name & Columns & Type & Description \\
\hline Record format & $1-8$ & Alphanumeric & STA93 (the format of the data record) \\
\hline Station & $9-18$ & Alphanumeric & $\begin{array}{l}\text { The identification of the station (the } \\
\text { facility identification and sampling } \\
\text { point) }\end{array}$ \\
\hline SRS north coordinate & $20-27$ & Numeric & $\begin{array}{l}\text { The SRS grid north coordinate of the } \\
\text { station reported in feet }\end{array}$ \\
\hline SRS east coordinate & $29-36$ & Numeric & $\begin{array}{l}\text { The SRS grid east coordinate of the } \\
\text { station reported in feet }\end{array}$ \\
\hline Ground elevation & $43-48$ & Numeric & $\begin{array}{l}\text { Ground elevation reported in feet above } \\
\text { median sea level }\end{array}$ \\
\hline
\end{tabular}


This is the description of the chain-of-custody data format, COC93, which is used for coding and transmitting chain-of-custody data records.

Table C.4. Chain-Of-Custody Data Format COC93

\begin{tabular}{|l|l|l|l|}
\hline Name & Columns & Type & Description \\
\hline Record format & $1-8$ & Alphanumeric & COC93 (the format of the data record) \\
\hline $\begin{array}{l}\text { Sample identification } \\
\text { number }\end{array}$ & $9-18$ & Integer & $\begin{array}{l}\text { The number of the sample printed on the } \\
\text { page of the sample logbook }\end{array}$ \\
\hline $\begin{array}{l}\text { Laboratory sample } \\
\text { identification }\end{array}$ & $19-33$ & Alphanumeric & $\begin{array}{l}\text { Identifier used for the sample by the } \\
\text { analytical laboratory }\end{array}$ \\
\hline Sample collection date & $34-39$ & Numeric & $\begin{array}{l}\text { Sample collection date recorded using the } \\
\text { MMDDYY format }\end{array}$ \\
\hline Shipping date & $40-45$ & Numeric & $\begin{array}{l}\text { Sample shipping date recorded using the } \\
\text { MMDDYY format }\end{array}$ \\
\hline $\begin{array}{l}\text { Cooler identification } \\
46-53\end{array}$ & Alphanumeric & $\begin{array}{l}\text { The number assigned to the cooler in which } \\
\text { the samples are shipped to the analytical } \\
\text { laboratory }\end{array}$ \\
\hline $\begin{array}{l}\text { Sample temperature } \\
\text { upon receipt }\end{array}$ & $\mathbf{5 4 - 5 7}$ & Numeric & $\begin{array}{l}\text { The temperature of the samples upon } \\
\text { receipt at the analytical laboratory in }{ }^{\circ} \mathrm{C}\end{array}$ \\
\hline
\end{tabular}

This is the description of the analytical data format, AN95, which is used for coding and transmitting analytical data records.

Table C.5. Analytical Data Format AN95

\begin{tabular}{|l|l|l|l|}
\hline Name & Columns & Type & Description \\
\hline WSRC identifier ${ }^{1}$ & $1-12$ & Alphanumeric & WSRC identifier for the sample \\
\hline COC number & $13-17$ & Alphanumeric & $\begin{array}{l}\text { Identifier of the sample's chain-of-custody } \\
\text { form (Required field for groundwater } \\
\text { samples; not used for soil samples) }\end{array}$ \\
\hline Sample collection date ${ }^{1}$ & $18-23$ & Numeric & $\begin{array}{l}\text { Date that the sample was collected. For } \\
\text { laboratory blanks and QC samples, enter } \\
\text { the preparation date. For TCLP samples, } \\
\text { enter the date of completion of TCLP } \\
\text { sample generation }\end{array}$ \\
\hline Sample collection time & $24-27$ & Numeric & Time of sample collection or generation \\
\hline Lab receipt date ${ }^{1}$ & $28-33$ & Numeric & $\begin{array}{l}\text { Date that the sample was received by the } \\
\text { laboratory; leave blank for laboratory } \\
\text { blanks and QC samples }\end{array}$ \\
\hline Extraction date & $34-39$ & Numeric & $\begin{array}{l}\text { Date that the sample was extracted; leave } \\
\text { blank unless the holding time is } \\
\text { dependent upon the extraction time }\end{array}$ \\
\hline
\end{tabular}

1 This field must have an entry for every record. 
Table C.5. Analytical Data Format AN95, continued

\begin{tabular}{|c|c|c|c|}
\hline Name & Columns & Type & Description \\
\hline Extraction time & $40-43$ & Numeric & $\begin{array}{l}\text { Time that the sample extraction was } \\
\text { started; leave blank unless the holding } \\
\text { time is dependent upon the extraction } \\
\text { time }\end{array}$ \\
\hline $\begin{array}{l}\text { Extraction/digestion } \\
\text { method }\end{array}$ & $44-56$ & Alphanumeric & $\begin{array}{l}\text { The coded identifier for the method used } \\
\text { to perform the extraction or digestion } \\
\text { (e.g., EPA\#.\#) }\end{array}$ \\
\hline Analysis date ${ }^{1}$ & $57-62$ & Numeric & $\begin{array}{l}\text { Date that the analyte concentration was } \\
\text { determined }\end{array}$ \\
\hline Analysis time $^{1}$ & $63-66$ & Numeric & $\begin{array}{l}\text { Time that the analyte concentration was } \\
\text { determined }\end{array}$ \\
\hline Analytical method ${ }^{1}$ & $67-79$ & Alphanumeric & $\begin{array}{l}\text { The coded identifier for the method used } \\
\text { to perform the analysis (e.g., EPA\#.\#) }\end{array}$ \\
\hline Preparation batch & $80-87$ & Alphanumeric & $\begin{array}{l}\text { Identification of the sample preparation } \\
\text { batch }\end{array}$ \\
\hline Laboratory $^{1}$ & $88-89$ & Alphanumeric & $\begin{array}{l}\text { Code assigned by EPD/EMS to identify } \\
\text { the laboratory performing the analysis }\end{array}$ \\
\hline $\begin{array}{l}\text { Laboratory sample } \\
\text { identification }^{1}\end{array}$ & $90-104$ & Alphanumeric & $\begin{array}{l}\text { Identifier used for the sample by the } \\
\text { analytical laboratory }\end{array}$ \\
\hline Laboratory replicate & $105-107$ & Alphanumeric & $\begin{array}{l}\text { Indicates that the sample is a non-blind } \\
\text { replicate analysis (see the end of this } \\
\text { appendix for codes) }\end{array}$ \\
\hline Analyte $^{1}$ & $108-117$ & Alphanumeric & $\begin{array}{l}\text { The coded identifier (provided by } \\
\text { EPD/EMS) for the analyte }\end{array}$ \\
\hline Quantitation limit & $118-125$ & Numeric & $\begin{array}{l}\text { GE and Weston report the ssEQL for non- } \\
\text { radiochemistry analyses. } \\
\text { All labs report the MDA for radio- } \\
\text { chemistry analyses }\end{array}$ \\
\hline Result qualifier & $126-128$ & Alphanumeric & $\begin{array}{l}\text { The coded field used to qualify the } \\
\text { analytical result (codes are in Appendix } \\
D \text { ) }\end{array}$ \\
\hline Analysis qualifier & $129-131$ & Alphanumeric & $\begin{array}{l}\text { The coded field used to qualify the } \\
\text { analysis (codes are in Appendix } D \text { ) }\end{array}$ \\
\hline Bias of analysis & 132 & Alphanumeric & $\begin{array}{l}\text { The coded field for data having result } \\
\text { qualifiers of } J \text { or } R \text { specifying the } \\
\text { expected bias (codes are in Appendix } D \text { ) }\end{array}$ \\
\hline Analytical result & $133-142$ & Numeric & $\begin{array}{l}\text { The concentration of the analyte. } \\
\text { For non-detects, the ssEQL is reported. } \\
\text { Results are reported on a dry weight basis } \\
\text { for all analyses reported in per mass units }\end{array}$ \\
\hline Result unit ${ }^{1}$ & $143-146$ & Alpha & $\begin{array}{l}\text { The coded identifier (provided by } \\
\text { EPD/EMS) of the unit in which the } \\
\text { analytical result is expressed }\end{array}$ \\
\hline
\end{tabular}


Table C.5. Analytical Data Format AN95, continued

\begin{tabular}{|c|c|c|c|}
\hline Name & Columns & Type & Description \\
\hline Accuracy & $147-154$ & Numeric & $\begin{array}{l}\text { The statistically determined value, } 95 \% \\
\text { confidence level, representing a plus or } \\
\text { minus value for the result and reported in } \\
\text { the same units as the analytical result; } \\
\text { required for all radiochemical analyses } \\
\text { above the detection limit but not generally } \\
\text { reported for non-radiochemical analyses. } \\
\text { Do not report more figures than are } \\
\text { significant }\end{array}$ \\
\hline Residual weight & $155-160$ & Numeric & $\begin{array}{l}\text { The weight of material in } \mathrm{mg} \text { the planchet } \\
\text { after evaporation; used for radionuclide } \\
\text { determinations }\end{array}$ \\
\hline Nominal concentration $^{1}$ & $161-168$ & Numeric & $\begin{array}{l}\text { The concentration of analyte added to the } \\
\text { sample prior to analysis; reported in the } \\
\text { same units as the analytical result; the } \\
\text { value of zero must be entered if the } \\
\text { sample was not spiked }\end{array}$ \\
\hline Percent recovery & $169-174$ & Numeric & $\begin{array}{l}\text { Recovery of the spiked constituent } \\
\text { reported as a percentage }\end{array}$ \\
\hline Number of dilutions ${ }^{1}$ & 175 & Numeric & $\begin{array}{l}\text { The number of steps required to reach the } \\
\text { final dilution factor; zero if the sample } \\
\text { was not diluted }\end{array}$ \\
\hline Dilution factor ${ }^{1}$ & $176-181$ & Numeric & $\begin{array}{l}\text { The dilution used in the analysis; a value } \\
\text { of one indicates the sample was not; } \\
\text { diluted }\end{array}$ \\
\hline Instrument $^{1}$ & $182-189$ & Alphanumeric & $\begin{array}{l}\text { The coded identifier for the instrument } \\
\text { used to perform the analysis; each } \\
\text { laboratory develops its own codes and } \\
\text { provides them to EPD/EMS }\end{array}$ \\
\hline Instrument batch 1 & $190-197$ & Alphanumeric & $\begin{array}{l}\text { The number assigned by the analytical } \\
\text { laboratory to the analysis batch (group of } \\
\text { samples analyzed together in a single } \\
\text { instrument run along with the associated } \\
\text { QC samples) }\end{array}$ \\
\hline Analyst's initials 1 & 198-200 & Alpha & The initials of the analyst \\
\hline Percent solids & 201-205 & Numeric & $\begin{array}{l}\text { The percentage of the sample that is dry } \\
\text { solids; required field if result is reported } \\
\text { in per mass units. Not applicable for } \\
\text { water samples }\end{array}$ \\
\hline Bottle label number & $206-215$ & Integer & $\begin{array}{l}\text { The number on the bottle label; required } \\
\text { field if bottle label is numbered }\end{array}$ \\
\hline Sample fraction & $216-219$ & Alphanumeric & $\begin{array}{l}\text { The coded identifier (provided by } \\
\text { EPD/EMS) for the fraction of the sample } \\
\text { analyzed }\end{array}$ \\
\hline Validation status & $220-221$ & Alphanumeric & The lab will report a zero \\
\hline
\end{tabular}


Table C.5. Analytical Data Format AN95, continued

\begin{tabular}{|l|l|l|l|}
\hline Name & Columns & Type & Description \\
\hline EPD/EMS receipt date & $222-227$ & Numeric & $\begin{array}{l}\text { Date that the analytical data is received } \\
\text { by EPD/EMS from the laboratory. The } \\
\text { laboratory will leave this blank }\end{array}$ \\
\hline ESH-EMS number & $228-234$ & Alphanumeric & $\begin{array}{l}\text { The document number assigned to the } \\
\text { project report }\end{array}$ \\
\hline
\end{tabular}

This is the description of the analytical data format, AN95-R2, which is used for coding and transmitting a subset of the AN95 analytical data records.

Table C.6. Analytical Data AN95-R2 Format

\begin{tabular}{|l|l|l|l|}
\hline Name & Columns & Type & Description \\
\hline Station identifier & $1-11$ & Alphanumeric & $\begin{array}{l}\text { Identification of the actual sample } \\
\text { (includes any modification made in the } \\
\text { field) }\end{array}$ \\
\hline Sample date & $12-18$ & Numeric & Date sample was collected \\
\hline Laboratory replicate & $19-21$ & Alphanumeric & $\begin{array}{l}\text { Indicates that the sample is a non-blind } \\
\text { replicate analysis (see the end of this } \\
\text { appendix for codes) }\end{array}$ \\
\hline Analyte & $22-71$ & Alphanumeric & Full analyte name \\
\hline Analysis type & $72-81$ & Alphanumeric & Analytical suite \\
\hline Quantitation limit & $82-89$ & Numeric & $\begin{array}{l}\text { Both GE and EMSL reported the ssEQL } \\
\text { for non-radiochemistry analyses. } \\
\text { All labs reported the MDA for } \\
\text { radiochemistry analyses }\end{array}$ \\
\hline Result qualifier & $90-92$ & Alphanumeric & $\begin{array}{l}\text { The coded field used to qualify the } \\
\text { analytical result (codes are in Appendix } \\
\text { D) }\end{array}$ \\
\hline Result & $\begin{array}{l}\text { The concentration of the analyte. } \\
\text { For non-detects, the ssEQL is reported. } \\
\text { Results were reported on a dry weight } \\
\text { basis for all analyses reported in per mass } \\
\text { units }\end{array}$ \\
\hline Validation status & $109-110$ & Alphanumeric & $\begin{array}{l}\text { The coded identifier (provided by } \\
\text { EPD/EMS) of the units in which the } \\
\text { analytical result is expressed } \\
\text { three }\end{array}$ \\
\hline ESH-EMS number & $111-117$ & Alphanumeric & $\begin{array}{l}\text { The document number assigned to the } \\
\text { project report }\end{array}$ \\
\hline
\end{tabular}


When making entries in the laboratory replicate field of the data files, use only the codes listed below.

Table C.7. Codes for Laboratory Replicates

\begin{tabular}{|l|l|}
\hline Remark & Definition \\
\hline (blank) & Data not remarked; the result is a routine analysis of a sample \\
\hline 1 & Laboratory replicate \\
\hline 2A & Matrix spike \\
\hline 2B & Matrix spike duplicate \\
\hline 2C & Surrogate spike \\
\hline 2D & Blank spike \\
\hline 2E & Blank spike duplicate \\
\hline 3 & Laboratory blank \\
\hline 4 & Re-analysis of a sample at the request of EPD/EMS \\
\hline CCB & Continuing calibration blank \\
\hline CCV & Continuing calibration verification sample \\
\hline ICB & Initial calibration blank \\
\hline ICS & Interference check sample \\
\hline ICV & Initial calibration verification sample \\
\hline
\end{tabular}

When making entries in the sample fraction field of the data files, use only the codes listed below.

\section{Table C.8. Codes for Fractions}

\begin{tabular}{|l|l|}
\hline Code & Description \\
\hline (blank) & The sample was not fractionated prior to analysis. \\
\hline A & Ashed fraction. \\
\hline D & Dried fraction of a soil or sludge sample. Not for use with water samples. \\
\hline F & Liquid fraction passing through a filter was analyzed. \\
\hline SL & Liquid fraction of a sample separated from the solid fraction. \\
\hline SS & Suspended soils. \\
\hline T & TCLP extraction. \\
\hline
\end{tabular}

When entering the identifiers for groundwater samples, use the following format for the WSRC identifier entered in the AN95 data file. 
Table C.9. WSRC Identifier for Groundwater Samples

\begin{tabular}{|l|l|l|l|}
\hline Name & Columns & Type & Description \\
\hline Well name & & & Alpha \\
\hline Series name & $1-3$ & $\begin{array}{l}\text { Name of the well series (except 241-H) } \\
\text { from which the sample was collected; } \\
\text { QA/QC laboratory deionized water } \\
\text { samples will have LB (the first character } \\
\text { is blank) as well series designation }\end{array}$ \\
\hline Cluster number & $4-6$ & Numeric & Number of the cluster (except 241-H) \\
\hline Well within cluster & $7-8$ & Alphanumeric & Can be blank \\
\hline & $9-10$ & Blank & Unused \\
\hline $\begin{array}{l}\text { Duplicate } \\
\text { identification }\end{array}$ & 11 & Alphanumeric & $\begin{array}{l}\text { Assigned by field personnel to identify } \\
\text { different sampling events occurring in one } \\
\text { day }\end{array}$ \\
\hline Secondary identifier & 12 & Alphanumeric & $\begin{array}{l}\text { Used as an alternate identifier by the } \\
\text { Groundwater Monitoring group of } \\
\text { EPD/EMS }\end{array}$ \\
\hline
\end{tabular}




\section{D.1 Qualifiers}

The following qualifiers were applied to the analytical results during data validation.

Table D.1. Result Qualifiers

\begin{tabular}{|l|l|}
\hline Qualifier & Description \\
\hline (blank) & The data are not remarked. The value should be interpreted exactly as reported. \\
\hline $\mathrm{C}^{1}$ & $\begin{array}{l}\text { Calculated. The analytical result reported was not measured directly but was } \\
\text { calculated from other data available. This does not apply to conversions, nor does it } \\
\text { apply to calculations made as part of an analytical procedure. }\end{array}$ \\
\hline $\mathrm{D}^{1}$ & Field measurement \\
\hline $\mathrm{I}$ & $\begin{array}{l}\text { The value in the result field is the instrument reading, not the sample quantitation } \\
\text { limit. Always used with the result qualifier } U .\end{array}$ \\
\hline $\mathrm{J}^{2}$ & $\begin{array}{l}\text { The analytical result is an estimated quantity. } \\
\text { Off-scale high. The actual value is not known, but it is known to be greater than the } \\
\text { value shown. }\end{array}$ \\
\hline $\mathrm{L}^{1}$ & $\begin{array}{l}\text { The result was rejected because performance requirements in the sample or } \\
\text { associated quality control analysis were not met. The analyte may or may not be } \\
\text { present. }\end{array}$ \\
\hline $\mathrm{R}^{1}$ & $\begin{array}{l}\text { Material analyzed for but not detected. The analyte concentration is less than the } \\
\text { ssEQL. NOTE: When both the result qualifier } U \text { and the result qualifier } I \text { are } \\
\text { reported, the numerical value in the result field is the instrument reading rather } \\
\text { than the ssEQL. }\end{array}$ \\
\hline $\mathrm{U}^{2}$
\end{tabular}

Table D.2. Analysis Qualifiers

\begin{tabular}{|l|l|}
\hline Qualifier & Description \\
\hline A & $\begin{array}{l}\text { GC/MS Compound Identification } \\
\text { Relative retention time or mass spectra criteria were not met. } \\
\text { Compound Identification } \\
\text { All anomalies. }\end{array}$ \\
\hline B & $\begin{array}{l}\text { The result is below the sample quantitation limit and above or equal to the } \\
\text { instrument detection limit. }\end{array}$ \\
\hline C & $\begin{array}{l}\text { Laboratory Control Sample } \\
\text { Criteria were not met. }\end{array}$ \\
\hline D & $\begin{array}{l}\text { ICP Serial Dilution } \\
\text { Criteria were not met. }\end{array}$ \\
\hline
\end{tabular}

1 This code is based on the STORET codes from the U.S. EPA.

2 This code is based on the CLP Laboratory Data Qualifiers from the U.S. EPA. 
Table D.2. Analysis Qualifiers, continued

\begin{tabular}{|c|c|}
\hline Qualifier & Description \\
\hline $\mathbf{E}$ & $\begin{array}{l}\text { The detected result is between the ssEQL and the method detection limit. Report } \\
\text { the actual result detected. }\end{array}$ \\
\hline $\mathrm{F}$ & $\begin{array}{l}\text { Pesticides Compound Identification } \\
\text { The pesticide result has been confirmed by gas chromatography/mass spectronetry. }\end{array}$ \\
\hline $\bar{G}$ & $\begin{array}{l}\text { Pesticides Instrument Performance } \\
\text { Used for all conditions outside criteria other than those flagged } N \text { (see code } N \\
\text { below). }\end{array}$ \\
\hline $\mathrm{H}$ & $\begin{array}{l}\text { Internal Standards Performance } \\
\text { Criteria were not met. }\end{array}$ \\
\hline $\bar{I}$ & $\begin{array}{l}\text { Matrix Spike/Matrix Spike Duplicate } \\
\text { Matrix Spike Sample Analysis } \\
\text { Spike recovery was not within control limits. }\end{array}$ \\
\hline $\mathrm{K}$ & $\begin{array}{l}\text { Tentatively Identified Compounds } \\
\text { A tentatively identified compound is a suspected aldol-condensation product. }\end{array}$ \\
\hline $\mathrm{L}$ & $\begin{array}{l}\text { Calibration Criteria Not Met } \\
\text { Calibration criteria (initial or continuing) were not met. See also } Z \text { for inorganics. }\end{array}$ \\
\hline $\mathbf{M}$ & $\begin{array}{l}\text { GC/MS Tuning } \\
\text { Mass calibration criteria were not met. }\end{array}$ \\
\hline $\mathbf{N}$ & $\begin{array}{l}\text { Tentatively Identified Compounds } \\
\text { All TIC results. }\end{array}$ \\
\hline $\mathrm{O}$ & $\begin{array}{l}\text { Surrogate Recovery } \\
\text { Surrogate spike recovery results are not within control limits. }\end{array}$ \\
\hline $\bar{P}$ & $\begin{array}{l}\text { Furnace Atomic Absorption QC } \\
\text { Duplicate injection precision criteria were not met, or post-digestion spike recovery } \\
\text { was not within control limits, but sample absorbance is greater than } 50 \% \text { of post- } \\
\text { digestion spike absorbance. }\end{array}$ \\
\hline Q & $\begin{array}{l}\text { Holding Time } \\
\text { Sample was held beyond normal holding time. }\end{array}$ \\
\hline $\mathbf{R}$ & $\begin{array}{l}\text { ICP Interference Check Sample } \\
\text { Criteria were not met. }\end{array}$ \\
\hline $\mathrm{S}$ & The reported value was determined by the method of standard additions. \\
\hline $\mathrm{V}$ & $\begin{array}{l}\text { Method Blank Contamination } \\
\text { The analyte was detected in both the sample and associated method blank. }\end{array}$ \\
\hline $\mathrm{W}$ & $\begin{array}{l}\text { Furnace Atomic Absorption QC } \\
\text { Post-digestion spike recovery for furnace atomic absorption analysis is not within } \\
\text { control limits while sample absorbance is less than } 50 \% \text { of spike absorbance. }\end{array}$ \\
\hline $\mathrm{X}$ & $\begin{array}{l}\text { Matrix Spike/Matrix Spike Duplicates } \\
\text { Laboratory Duplicate Sample Analysis } \\
\text { Duplicate analysis relative percent difference is not within control limits. }\end{array}$ \\
\hline $\mathrm{Y}$ & Result obtained from unpreserved or improperly preserved sample. \\
\hline $\mathrm{Z}$ & $\begin{array}{l}\text { Calibration } \\
\text { Furnace Atomic Absorption QC } \\
\text { Correlation coefficient was less than } 0.995 \text {. }\end{array}$ \\
\hline
\end{tabular}


Table D.2. Analysis Qualifiers, continued

\begin{tabular}{|l|l|}
\hline Qualifier & Description \\
\hline 4 & Matrix interference. Value cannot be determined. \\
\hline 5 & $\begin{array}{l}\text { The analytical value was four times higher than the standard concentration, and } \\
\text { percent recovery cannot be determined. }\end{array}$ \\
\hline 6 & The analyte was detected in both the sample and associated field blank. \\
\hline 7 & $\begin{array}{l}\text { The analyte was detected in both the sample and associated rinsate or equipment } \\
\text { blank. }\end{array}$ \\
\hline 8 & The analyte was detected in both the sample and associated trip blank. \\
\hline 9 & $\begin{array}{l}\text { Field Duplicate Sample Analysis } \\
\text { Duplicate analysis relative percent difference is not within control limits. }\end{array}$ \\
\hline
\end{tabular}

Table D.3. Bias Codes

\begin{tabular}{|l|l|}
\hline Qualifier & Description \\
\hline L & $\begin{array}{l}\text { Analytical factor causing bias. The associated result may underestimate the true } \\
\text { value. }\end{array}$ \\
\hline H & $\begin{array}{l}\text { Analytical factor causing bias. The associated result may overestimate the true } \\
\text { value. }\end{array}$ \\
\hline
\end{tabular}




\section{D.2 Number of Qualified Samples}

The following table presents the samples requested, received, and qualified for each analyte. Analytical results for both the primary laboratory and the laboratory receiving QA samples are included in the table. Surrogates, matrix spikes, and other laboratory QC results are not included in the table.

- The Samples Requested column contains the number of times the laboratory received a COC and its associated sample (environmental samples, field-generated duplicates, field blanks, and trip blanks) requesting that a particular analysis be performed.

- The Samples Received column contains the total number of samples for which at least one analytical record was reported.

- The Analyses Reported column contains the total number of reported results for the analyte. This number includes laboratory-initiated duplicate analyses and re-analysis results; it does not include analyses of associated laboratory blanks.

The remaining columns in the table list the number of analyses that were qualified for meeting specified conditions.

- The Records Rejected column contains the number of records for which the RQ was $R$. Samples having a rejected result also may have an acceptable re-analysis result.

- The column Out of Holding contains the number of records for which the time between sample collection and analysis exceeded the maximum allowed by the analytical method. These records have an $\mathrm{AQ}$ of $Q$. All laboratory $\mathrm{pH}$ measurements exceed holding time, regardless of the laboratory's efficiency.

- The column QAQQC Problems contains the number of records containing an AQ of $C$, $H, I, O, V$, or $X$ because at least one associated laboratory QC sample did not meet the required standards.

- The column Preservation contains the number of records with preservation problems. These records have an $\mathrm{AQ}$ of $Y$.

- The column Calibration contains the number of records with identified calibration problems. These records have an AQ of $L$. 
Table D.4. Number of Qualified Samples

\begin{tabular}{|l|l|l|l|l|l|l|l|l|}
\hline Analyte & $\begin{array}{l}\text { Samples } \\
\text { Requested }\end{array}$ & $\begin{array}{l}\text { Samples } \\
\text { Received }\end{array}$ & $\begin{array}{l}\text { Analyses } \\
\text { Reported }\end{array}$ & $\begin{array}{l}\text { Records } \\
\text { Rejected }\end{array}$ & $\begin{array}{l}\text { Out of } \\
\text { Holding }\end{array}$ & $\begin{array}{l}\text { QA/QC } \\
\text { Problems }\end{array}$ & $\begin{array}{l}\text { Preser- } \\
\text { vation }\end{array}$ & $\begin{array}{l}\text { Calib- } \\
\text { ration }\end{array}$ \\
\hline Radionuclides \\
\hline Tritium & 129 & 129 & 138 & 0 & 0 & 0 & 0 & 0 \\
\hline
\end{tabular}

Table D.5. Number of Analytical Records by Method and Type of Record

\begin{tabular}{|l|l|l|l|l|l|l|}
\hline $\begin{array}{l}\text { Analytical } \\
\text { Method }\end{array}$ & $\begin{array}{l}\text { Sample } \\
\text { Records }\end{array}$ & $\begin{array}{l}\text { Laboratory } \\
\text { Duplicates }\end{array}$ & $\begin{array}{l}\text { Laboratory } \\
\text { Blanks }\end{array}$ & $\begin{array}{l}\text { Matrix } \\
\text { Spikes/ } \\
\text { Duplicates }\end{array}$ & $\begin{array}{l}\text { Calibra- } \\
\text { tion } \\
\text { Checks }\end{array}$ & Totals \\
\hline 3Q1-6-1420 & 17 & 3 & 14 & 3 & 0 & 37 \\
\hline EPA906.0 & 112 & 6 & 14 & 6 & 0 & 138 \\
\hline
\end{tabular}

Table D.6. Analytes Detected in Background and Water Samples

\begin{tabular}{|l|l|l|l|}
\hline & $\begin{array}{l}\text { Average } \\
\text { Result }\end{array}$ & Min/Max Results & Unit \\
\hline Analytes Detected in Background Water Samples \\
\hline Tritium & 201 & $28.9 / 520$ & $\mathrm{pCi} / \mathrm{mL}$ \\
\hline Analytes Detected in Water Samples & 692000 & $7.05 / 1910000$ & $\mathrm{pCi} / \mathrm{mL}$ \\
\hline Tritium & & \\
\hline
\end{tabular}




\section{D.3 Analytical Results Sorted by Sample}

Table D.7. Water Results Sorted by Sample

SURVEY ID: FHB 0101

SAMPLE ID: 106500

Survey location: $54075 \mathrm{E}$ 73758N (SRS coordinates)

Sample type: Normal

Sample matrix: Water

Constituent

RQ AQ B Result

Unit MDA

Method

Radionuclides

Tritium

$1.02 \mathrm{E}+02 \pm 2.20 \mathrm{E}+00 \mathrm{pCi} / \mathrm{mL} \quad 1.06 \mathrm{E}+00$

EPA906.0

SURVEY ID: FHB 0201

SAMPLE ID: 106501

Survey location: $54095 \mathrm{E} 73540 \mathrm{~N}$ (SRS coordinates)

Sample type: Normal

Sample matrix: Water

Radionuclides

Tritium

$1.54 \mathrm{E}+01 \pm 6.42 \mathrm{E}-01 \quad \mathrm{pCi} / \mathrm{mL} \quad 5.04 \mathrm{E}-01$

EPA906.0

SURVEY ID: FHB 0201D

SAMPLE ID: 106502

Sample type: Split

Associated sample: 106501

Radionuclides

Tritium

UI

UI

$3.72 \mathrm{E}+00 \pm 1.49 \mathrm{E}+01 \mathrm{pCi} / \mathrm{mL} \quad 5.87 \mathrm{E}+04$

$3 Q 1-6-1420$

Tritium

$4.84 \mathrm{E}+00 \pm 1.49 \mathrm{E}+01 \mathrm{pCi} / \mathrm{mL} \quad 5.87 \mathrm{E}+04$

3Q1-6-1420

SURVEY ID: FHB 0202

SAMPLE ID: 108943

Survey location: $54095 \mathrm{E} 73540 \mathrm{~N}$ (SRS coordinates)

Sample type: Normal

Sample matrix: Water

Radionuclides

Tritium

$1.63 \mathrm{E}+01 \pm 6.45 \mathrm{E}-01 \mathrm{pCi} / \mathrm{mL} \quad 4.94 \mathrm{E}-01$

EPA906.0

SURVEY ID: FHB 0301

SAMPLE ID: 106512

Survey location: $53712 \mathrm{E} 73236 \mathrm{~N}$ (SRS coordinates)

Sample type: Normal

Sample matrix: Water

Radionuclides

Tritium

$1.15 \mathrm{E}+02 \pm 1.99 \mathrm{E}+00 \mathrm{pCi} / \mathrm{mL} \quad 7.89 \mathrm{E}-01$

EPA906.0 
SURVEY ID: FHB 0302

SAMPLE ID: 108953

Survey location: $53712 \mathrm{E} 73236 \mathrm{~N}$ (SRS coordinates)

Sample type: Normal

Sample matrix: Water

Constituent

RQ AQ B Result

Unit MDA

Method

Radionuclides

Tritium

EPA906.0

SURVEY ID: FHB 0401

SAMPLE ID: 106513

Survey location: 53741E 73029N (SRS coordinates)

Sample type: Normal

Sample matrix: Water

Radionuclides

Tritium

SURVEY ID: FHB 0402

SAMPLE ID: 108954

Survey location: $53741 \mathrm{E} 73029 \mathrm{~N}$ (SRS coordinates)

Sample type: Normal

Sample matrix: Water

Radionuclides

Tritium

$2.47 \mathrm{E}+02 \pm 2.37 \mathrm{E}+00 \mathrm{pCi} / \mathrm{mL} \quad 5.35 \mathrm{E}-01$

EPA906.0

SURVEY ID: FHB 0501

SAMPLE ID: 106515

Survey location: 53910E 72800N (SRS coordinates)

Sample type: Normal

Sample matrix: Water

\section{Radionuclides}

Tritium

$4.06 \mathrm{E}+02 \pm 2.99 \mathrm{E}+00 \mathrm{pCi} / \mathrm{mL} \quad 5.17 \mathrm{E}-01$

EPA906.0

SURVEY ID: FHB 0502

SAMPLE ID: 108960

Survey location: 53910E 72800N (SRS coordinates)

Sample type: Normal

Sample matrix: Water

Radionuclides

Tritium

$4.96 \mathrm{E}+02 \pm 3.28 \mathrm{E}+00 \quad \mathrm{pCi} / \mathrm{mL} \quad 5.16 \mathrm{E}-01$

EPA906.0

SURVEY ID: FHB 0601

SAMPLE ID: 106514

Survey location: 54129E 72672N (SRS coordinates)

Sample type: Normal

Sample matrix: Water

Radionuclides

Tritium

$2.07 \mathrm{E}+02 \pm 2.01 \mathrm{E}+00 \mathrm{pCi} / \mathrm{mL} \quad 4.47 \mathrm{E}-01$

EPA906.0 
SURVEY ID: FHB 0602

SAMPLE ID: 108958

Survey location: $54129 \mathrm{E} 72672 \mathrm{~N}$ (SRS coordinates)

Sample type: Normal

Sample matrix: Water

Constituent

RQ AQ B Result

Unit MDA

Method

Radionuclides

Tritium

$2.11 \mathrm{E}+02 \pm 2.67 \mathrm{E}+00 \mathrm{pCi} / \mathrm{mL} \quad 6.42 \mathrm{E}-01$

EPA906.0

SURVEY ID: FHB 0602D

SAMPLE ID: 108959

Sample type: Split

Associated sample: 108958

Radionuclides

Tritium

$2.12 \mathrm{E}+02 \pm 1.62 \mathrm{E}+00 \mathrm{pCi} / \mathrm{mL} \quad 1.17 \mathrm{E}+03$

3Q1-6-1420

Tritium

SURVEY ID: FHB 0801

SAMPLE ID: 106516

Survey location: 54022E 72181N (SRS coordinates)

Sample type: Normal

Sample matrix: Water

Radionuclides

Tritium

Tritium

$1.58 \mathrm{E}+02 \pm 1.78 \mathrm{E}+00 \mathrm{pCi} / \mathrm{mL} \quad 4.58 \mathrm{E}-01$

$1.55 \mathrm{E}+02 \pm 1.76 \mathrm{E}+00 \mathrm{pCi} / \mathrm{mL} \quad 4.58 \mathrm{E}-01$

EPA906.0

EPA906.0

SURVEY ID: FHB 0802

SAMPLE ID: 108961

Survey location: $54022 \mathrm{E} 72181 \mathrm{~N}$ (SRS coordinates)

Sample type: Normal

Sample matrix: Water

Radionuclides

Tritium

$2.00 \mathrm{E}+02 \pm 2.09 \mathrm{E}+00 \mathrm{pCi} / \mathrm{mL} \quad 5.14 \mathrm{E}-01$

EPA906.0

SURVEY ID: FHB 1201

SAMPLE ID: 106506

Survey location: $53878 \mathrm{E} 73424 \mathrm{~N}$ (SRS coordinates)

Sample type: Normal

Sample matrix: Water

Radionuclides

Tritium

$1.50 \mathrm{E}+04 \pm 5.52 \mathrm{E}+02 \quad \mathrm{pCi} / \mathrm{mL} \quad 3.00 \mathrm{E}+01$

EPA906.0

SURVEY ID: FHB 1202

SAMPLE ID: 108952

Survey location: $53878 \mathrm{E} 73424 \mathrm{~N}$ (SRS coordinates)

Sample type: Normal

Sample matrix: Water

Radionuclides

Tritium

$1.85 \mathrm{E}+04 \pm 1.82 \mathrm{E}+02 \mathrm{pCi} / \mathrm{mL} \quad 1.17 \mathrm{E}+05$

$3 Q 1-6-1420$ 
SURVEY ID: FHB 1301 SAMPLE ID: 106505

Survey location: $53848 \mathrm{E} 73508 \mathrm{~N}$ (SRS coordinates)

Sample type: Normal

Sample matrix: Water

Constituent

RQ AQ B Result

Unit MDA

Method

Radionuclides

Tritium

EPA906.0

SURVEY ID: FHB 1302

SAMPLE ID: 108950

Survey location: $53848 \mathrm{E} 73508 \mathrm{~N}$ (SRS coordinates)

Sample type: Normal

Sample matrix: Water

\section{Radionuclides}

Tritium

SURVEY ID: FHB 1401

SAMPLE ID: 106507

Survey location: 53728E 73561N (SRS coordinates)

Sample type: Normal

Sample matrix: Water

Radionuclides

Tritium

$3.07 \mathrm{E}+02 \pm 2.43 \mathrm{E}+00 \mathrm{pCi} / \mathrm{mL} \quad 4.42 \mathrm{E}-01$

EPA906.0

SURVEY ID: FHB 1402

SAMPLE ID: 108951

Survey location: 53728E 73561N (SRS coordinates)

Sample type: Normal

Sample matrix: Water

Radionuclides

Tritium

SURVEY ID: FHB 1601

SAMPLE ID: 106510

Survey location: 54030E $73716 \mathrm{~N}$ (SRS coordinates)

Sample type: Normal

Sample matrix: Water

Radionuclides

Tritium

SURVEY ID: FHB 1602

SAMPLE ID: 108944

Survey location: $54030 \mathrm{E} 73716 \mathrm{~N}$ (SRS coordinates)

Sample type: Normal

Sample matrix: Water

Radionuclides

Tritium

$2.78 \mathrm{E}+02 \pm 2.39 \mathrm{E}+00 \mathrm{pCi} / \mathrm{mL} \quad 4.87 \mathrm{E}-01$

EPA906.0 
SURVEY ID: FHB 1701

SAMPLE ID: 106509

Survey location: $54000 \mathrm{E} 73668 \mathrm{~N}$ (SRS coordinates)

Sample type: Normal

Sample matrix: Water

Constituent

RQ AQ B Result

Unit MDA

Method

Radionuclides

Tritium

$1.04 \mathrm{E}+04 \pm 6.62 \mathrm{E}+02 \mathrm{pCi} / \mathrm{mL} \quad 9.55 \mathrm{E}+01$

EPA906.0

SURVEY ID: FHB 1702

SAMPLE ID: 108947

Survey location: $54000 \mathrm{E} 73668 \mathrm{~N}$ (SRS coordinates)

Sample type: Normal

Sample matrix: Water

Radionuclides

Tritium

$8.83 \mathrm{E}+03 \pm 1.20 \mathrm{E}+02 \mathrm{pCi} / \mathrm{mL} \quad 1.17 \mathrm{E}+05$

$3 Q 1-6-1420$

SURVEY ID: FHB 1801

SAMPLE ID: 106508

Survey location: $54026 \mathrm{E} 73565 \mathrm{~N}$ (SRS coordinates)

Sample type: Normal Sample matrix: Water

Radionuclides

Tritium

$2.02 \mathrm{E}+04 \pm 6.01 \mathrm{E}+02 \mathrm{pCi} / \mathrm{mL} \quad 2.62 \mathrm{E}+01$

EPA906.0

SURVEY ID: FHB 1802

SAMPLE ID: 108948

Survey location: 54026E $73565 \mathrm{~N}$ (SRS coordinates)

Sample type: Normal Sample matrix: Water

Radionuclides

Tritium

$1.91 \mathrm{E}+04 \pm 1.89 \mathrm{E}+02 \mathrm{pCi} / \mathrm{mL} \quad 1.17 \mathrm{E}+05$

$3 Q 1-6-1420$

SURVEY ID: FHB 1901

SAMPLE ID: 106504

Survey location: $53895 \mathrm{E} 73485 \mathrm{~N}$ (SRS coordinates)

Sample type: Normal

Sample matrix: Water

Radionuclides

Tritium

$5.63 \mathrm{E}+03 \pm 3.69 \mathrm{E}+02 \mathrm{pCi} / \mathrm{mL} \quad 6.67 \mathrm{E}+01$

EPA906.0

SURVEY ID: FHB 2001

SAMPLE ID: 106503

Survey location: $54008 \mathrm{E} 73434 \mathrm{~N}$ (SRS coordinates)

Sample type: Normal

Sample matrix: Water

Radionuclides

Tritium

$2.41 \mathrm{E}+01 \pm 7.70 \mathrm{E}-01 \quad \mathrm{pCi} / \mathrm{mL} \quad 5.00 \mathrm{E}-01$

EPA906.0 
SURVEY ID: FHB 2001A

Sample type: Duplicate

Constituent

Radionuclides

Tritium

SURVEY ID: FHB 2002
SAMPLE ID: 106542

Associated sample: 106503

RQ AQ B Result

Unit MDA

Method

$$
2.35 \mathrm{E}+01 \pm 7.67 \mathrm{E}-01 \quad \mathrm{pCi} / \mathrm{mL} \quad 5.07 \mathrm{E} \cdot 01
$$

EPA906.0

SAMPLE ID: 108942

Survey location: $54008 \mathrm{E} 73434 \mathrm{~N}$ (SRS coordinates)

Sample type: Normal

Sample matrix: Water

Radionuclides

Tritium

$2.18 \mathrm{E}+01 \pm 7.08 \mathrm{E}-01 \quad \mathrm{pCi} / \mathrm{mL} \quad 4.70 \mathrm{E}-01$

EPA906.0

SAMPLE ID: 106539

SURVEY ID: FMC 1F01

Survey location: $57050 \mathrm{E}$ 70350N (SRS coordinates)
Sample type: Normal

Radionuclides

Tritium

$4.56 \mathrm{E}+02 \pm 2.97 \mathrm{E}+00 \mathrm{pCi} / \mathrm{mL} \quad 4.47 \mathrm{E}-01$

EPA906.0

SURVEY ID: FMC 1F02

SAMPLE ID: 108964

Survey location: $57050 \mathrm{E} 70350 \mathrm{~N}$ (SRS coordinates)

Sample type: Normal

Sample matrix: Water

\section{Radionuclides}

Tritium

$5.20 \mathrm{E}+02 \pm 3.22 \mathrm{E}+00 \mathrm{pCi} / \mathrm{mL} \quad 4.75 \mathrm{E}-01$

EPA906.0

SURVEY ID: FMC 1H01

SAMPLE ID: 106562

Survey location: $5300 \mathrm{E} 72600 \mathrm{~N}$ (SRS coordinates)

Sample type: Normal

Sample matrix: Water

Radionuclides

Tritium

$2.89 \mathrm{E}+01 \pm 1.23 \mathrm{E}+00 \mathrm{pCi} / \mathrm{mL} \quad 7.10 \mathrm{E}-01$

EPA906.0

SURVEY ID: FMC $1 \mathrm{H} 02$

SAMPLE ID: 108962

Survey location: 5300E $72600 \mathrm{~N}$ (SRS coordinates)

Sample type: Normal

Sample matrix: Water

Radionuclides

Tritium

$3.46 \mathrm{E}+01 \pm 8.66 \mathrm{E}-01 \quad \mathrm{pCi} / \mathrm{mL} \quad 4.70 \mathrm{E}-01$

EPA906.0 
SURVEY ID: FMC 2H01

SAMPLE ID: 106567

Survey location: $53000 \mathrm{E} 72600 \mathrm{~N}$ (SRS coordinates)

Sample type: Normal Sample matrix: Water

\section{Constituent}

RQ AQ B Result

Unit MDA

Method

Radionuclides

Tritium

EPA906.0

SURVEY ID: FMC 2H01D

SAMPLE ID: 106568

Sample type: Split

Associated sample: 106567

Radionuclides

Tritium

SURVEY ID: FMC $2 \mathrm{H} 02$

SAMPLE ID: 108963

Survey location: $53000 \mathrm{E} 72600 \mathrm{~N}$ (SRS coordinates)

Sample type: Normal

Sample matrix: Water

Radionuclides

Tritium

$7.55 \mathrm{E}+01 \pm 1.25 \mathrm{E}+00 \mathrm{pCi} / \mathrm{mL} \quad 4.73 \mathrm{E}-01$

EPA906.0

SURVEY ID: FMC 2H02D

SAMPLE ID: 108966

Sample type: Split

Associated sample: 108963

Radionuclides

Tritium

SURVEY ID: FSP 0201

SAMPLE ID: 106528

Survey location: 49133E 72796N (SRS coordinates)

Sample type: Normal

Sample matrix: Water

Radionuclides

Tritium

SURVEY ID: FSP 0201A

Sample type: Duplicate

Radionuclides

Tritium
SAMPLE ID: 106529

Associated sample: 106528

$6.13 \mathrm{E}+02 \pm 3.43 \mathrm{E}+00 \mathrm{pCi} / \mathrm{mL} \quad 4.44 \mathrm{E}-01$
EPA906.0 
SURVEY ID: FSP 0202

SAMPLE ID: 108911

Survey location: 49133E 72796N (SRS coordinates)

Sample type: Normal

Sample matrix: Water

Constituent

RQ AQ B Result

Unit MDA

Method

Radionuclides

Tritium

EPA906.0

SURVEY ID: FSP 0701

SAMPLE ID: 106527

Survey location: 49540E 73008N (SRS coordinates)

Sample type: Normal

Sample matrix: Water

Radionuclides

Tritium

$8.09 \mathrm{E}+02 \pm 6.55 \mathrm{E}+00 \mathrm{pCi} / \mathrm{mL} \quad 1.06 \mathrm{E}+00$

EPA906.0

SURVEY ID: FSP 0702

SAMPLE ID: 108912

Survey location: $49540 \mathrm{E} 73008 \mathrm{~N}$ (SRS coordinates)

Sample type: Normal

Sample matrix: Water

Radionuclides

Tritium

SURVEY ID: FSP 1201

SAMPLE ID: 106530

Survey location: 49644E 73602N (SRS coordinates)

Sample type: Normal

Sample matrix: Water

Radionuclides

Tritium

$1.95 \mathrm{E}+01 \pm 6.96 \mathrm{E}-01 \quad \mathrm{pCi} / \mathrm{mL} \quad 4.91 \mathrm{E}-01$

$1.87 \mathrm{E}+01 \pm 7.18 \mathrm{E}-01 \quad \mathrm{pCi} / \mathrm{mL} \quad 5.35 \mathrm{E}-01$

EPA906.0

Tritium

SAMPLE ID: 108913

SURVEY ID: FSP 1202

coordinates)

Survey location: 4964

Sample matrix: Water

Radionuclides

Tritium

SURVEY ID: FSP 1401

SAMPLE ID: 106534

Survey location: 49802E 73685N (SRS coordinates)

Sample type: Normal

Sample matrix: Water

Radionuclides

Tritium

$1.08 \mathrm{E}+01 \pm 7.45 \mathrm{E}-01 \quad \mathrm{pCi} / \mathrm{mL} \quad 7.82 \mathrm{E}-01$

EPA906.0 
SURVEY ID: FSP 1402

SAMPLE ID: 108921

Survey location: 49802E 73685N (SRS coordinates)

Sample type: Normal

Sample matrix: Water

\section{Constituent}

RQ AQ B Result

Unit

MDA

Method

Radionuclides

Tritium

$5.08 \mathrm{E}+01 \pm 1.28 \mathrm{E}+00 \mathrm{pCi} / \mathrm{mL} \quad 6.00 \mathrm{E}-01$

EPA906.0

SURVEY ID: FSP 1901

SAMPLE ID: 106531

Survey location: 49778E 73177N (SRS coordinates)

Sample type: Normal

Sample matrix: Water

Radionuclides

Tritium

$4.53 \mathrm{E}+03 \pm 3.07 \mathrm{E}+02 \mathrm{pCi} / \mathrm{mL} \quad 3.06 \mathrm{E}+01$

EPA906.0

SURVEY ID: FSP 1902

SAMPLE ID: 108914

Survey location: 49778E 73177N (SRS coordinates)

Sample type: Normal

Sample matrix: Water

Radionuclides

Tritium

SURVEY ID: FSP 2601

SAMPLE ID: 106533

Survey location: 49801E 72932N (SRS coordinates)

Sample type: Normal

Sample matrix: Water

\section{Radionuclides}

Tritium

$7.74 \mathrm{E}+03 \pm 3.99 \mathrm{E}+02 \quad \mathrm{pCi} / \mathrm{mL} \quad 3.04 \mathrm{E}+01$

EPA906.0

SURVEY ID: FSP 2602

SAMPLE ID: 108915

Survey location: 49801E 72932N (SRS coordinates)

Sample type: Normal

Sample matrix: Water

Radionuclides

Tritium

$3.98 \mathrm{E}+03 \pm 3.06 \mathrm{E}+01 \mathrm{pCi} / \mathrm{mL} \quad 1.17 \mathrm{E}+04$

3Q1-6-1420

SURVEY ID: FSP 2602A

Sample type: Duplicate

Radionuclides

Tritium

Tritium
SAMPLE ID: 108916

Associated sample: 108915

$4.02 \mathrm{E}+03 \pm 3.09 \mathrm{E}+01 \mathrm{pCi} / \mathrm{mL} \quad 1.17 \mathrm{E}+04$

$3.92 \mathrm{E}+03 \pm 3.00 \mathrm{E}+01 \mathrm{pCi} / \mathrm{mL} \quad 1.17 \mathrm{E}+04$
3Q1-6-1420

$3 Q 1-6-1420$ 
SURVEY ID: FSP 3201

SAMPLE ID: 106532

Survey location: 50258E 73367N (SRS coordinates)

Sample type: Normal

Sample matrix: Water

Constituent

RQ AQ B Result

Unit MDA

Method

Radionuclides

Tritium

EPA906.0

SURVEY ID: FSP 3202

SAMPLE ID: 108917

Survey location: 50258E 73367N (SRS coordinates)

Sample type: Normal

Sample matrix: Water

Radionuclides

Tritium

$2.32 \mathrm{E}+02 \pm 2.83 \mathrm{E}+00 \quad \mathrm{pCi} / \mathrm{mL} \quad 6.56 \mathrm{E}-01$

EPA906.0

Tritium

SURVEY ID: FSP 3401

SAMPLE ID: 106566

Survey location: $50261 \mathrm{E} 73156 \mathrm{~N}$ (SRS coordinates)

Sample type: Normal

Sample matrix: Water

Radionuclides

Tritium

$6.77 \mathrm{E}+02 \pm 4.29 \mathrm{E}+00 \mathrm{pCi} / \mathrm{mL} \quad 6.49 \mathrm{E}-01$

EPA906.0

SURVEY ID: FSP 3402

SAMPLE ID: 108967

Survey location: 50261E $73156 \mathrm{~N}$ (SRS coordinates)

Sample type: Normal

Sample matrix: Water

Radionuclides

Tritium

$2.91 \mathrm{E}+03 \pm 1.04 \mathrm{E}+01 \mathrm{pCi} / \mathrm{mL} \quad 1.44 \mathrm{E}+00$

EPA906.0

Tritium $2.92 \mathrm{E}+03 \pm 1.04 \mathrm{E}+01 \mathrm{pCi} / \mathrm{mL} \quad 1.43 \mathrm{E}+00$

EPA906.0

SURVEY ID: FSP 3501

SAMPLE ID: 106537

Survey location: 50297E 73065N (SRS coordinates)

Sample type: Normal

Sample matrix: Water

Radionuclides

Tritium

$5.26 \mathrm{E}+03 \pm 3.28 \mathrm{E}+02 \quad \mathrm{pCi} / \mathrm{mL} \quad 3.02 \mathrm{E}+01$

EPA906.0

SURVEY ID: FSP 3502

SAMPLE ID: 108918

Survey location: 50297E 73065N (SRS coordinates)

Sample type: Normal

Sample matrix: Water

Radionuclides

Tritium

$7.15 \mathrm{E}+03 \pm 7.86 \mathrm{E}+01 \quad \mathrm{pCi} / \mathrm{mL} \quad 5.87 \mathrm{E}+04$

$3 Q 1-6-1420$

Fourmile Branch and the F- and H-Area Seeplines, Tritium 
SURVEY ID: FSP 4001

SAMPLE ID: 106536

Survey location: 50630E 73101N (SRS coordinates)

Sample type: Normal

Sample matrix: Water

Constituent

RQ AQ B Result

Unit MDA

Method

Radionuclides

Tritium

EPA906.0

SURVEY ID: FSP 4002

SAMPLE ID: 108919

Survey location: $50630 \mathrm{E} 73101 \mathrm{~N}$ (SRS coordinates)

Sample type: Normal

Sample matrix: Water

Radionuclides

Tritium

$4.64 \mathrm{E}+03 \pm 3.42 \mathrm{E}+01 \mathrm{pCi} / \mathrm{mL} \quad 1.17 \mathrm{E}+04$

3Q1-6-1420

SURVEY ID: FSP 4701

SAMPLE ID: 106535

Survey location: 50607E 73609N (SRS coordinates)

Sample type: Normal

Sample matrix: Water

Radionuclides

Tritium

$1.53 \mathrm{E}+01 \pm 7.04 \mathrm{E}-01 \quad \mathrm{pCi} / \mathrm{mL} \quad 5.35 \mathrm{E}-01$

EPA906.0

SURVEY ID: FSP 4702

SAMPLE ID: 108920

Survey location: 50607E 73609N (SRS coordinates)

Sample type: Normal

Sample matrix: Water

Radionuclides

Tritium

$2.00 \mathrm{E}+01 \pm 8.55 \mathrm{E}-01 \quad \mathrm{pCi} / \mathrm{mL} \quad 6.13 \mathrm{E}-01$

EPA906.0

SURVEY ID: FSP 5601

SAMPLE ID: 106538

Survey location: $51488 \mathrm{E} 73824 \mathrm{~N}$ (SRS coordinates)

Sample type: Normal

Sample matrix: Water

Radionuclides

Tritium

$7.38 \mathrm{E}+00 \pm 4.54 \mathrm{E}-01 \quad \mathrm{pCj} / \mathrm{mL} \quad 4.44 \mathrm{E}-01$

EPA906.0

SURVEY ID: FSP 5602

SAMPLE ID: 108922

Survey location: $51488 \mathrm{E} 73824 \mathrm{~N}$ (SRS coordinates)

Sample type: Normal

Sample matrix: Water

Radionuclides

Tritium

$7.05 \mathrm{E}+00 \pm 5.94 \mathrm{E}-01 \quad \mathrm{pCi} / \mathrm{mL} \quad 6.33 \mathrm{E}-01$

EPA906.0 
SURVEY ID: FSP 20401

SAMPLE ID: 106517

Survey location: $48801 \mathrm{E} 73281 \mathrm{~N}$ (SRS coordinates)

Sample type: Normal

Sample matrix: Water

Constituent

RQ AQ B Result

Unit MDA

Method

Radionuclides

Tritium

EPA906.0

SURVEY ID: FSP 20402

SAMPLE ID: 108900

Survey location: 48801E 73281N (SRS coordinates)

Sample type: Normal

Sample matrix: Water

Radionuclides

Tritium

$2.88 \mathrm{E}+03 \pm 2.43 \mathrm{E}+01 \mathrm{pCi} / \mathrm{mL} \quad 1.17 \mathrm{E}+04$

3Q1-6-1420

SURVEY ID: FSP 21301

SAMPLE ID: 106518

Survey location: 48725E $73486 \mathrm{~N}$ (SRS coordinates)

Sample type: Normal

Sample matrix: Water

Radionuclides

Tritium

$1.79 \mathrm{E}+03 \pm 1.11 \mathrm{E}+02 \mathrm{pCi} / \mathrm{mL} \quad 1.39 \mathrm{E}+01$

EPA906.0

SURVEY ID: FSP 21302

SAMPLE ID: 108901

Survey location: 48725E 73486N (SRS coordinates)

Sample type: Normal

Sample matrix: Water

Radionuclides

Tritium

SURVEY ID: FSP 22001

SAMPLE ID: 106520

Survey location: 48644E $72983 \mathrm{~N}$ (SRS coordinates)

Sample type: Normal

Sample matrix: Water

Radionuclides

Tritium

SURVEY ID: FSP 22002

SAMPLE ID: 108905

Survey location: 48644E 72983N (SRS coordinates)

Sample type: Normal

Sample matrix: Water

\section{Radionuclides}

Tritium

$9.55 \mathrm{E}+02 \pm 5.96 \mathrm{E}+00 \mathrm{pCi} / \mathrm{mL} \quad 7.15 \mathrm{E}-01$

EPA906.0 
SURVEY ID: FSP 22601

SAMPLE ID: 106519

Survey location: $48601 \mathrm{E} 73308 \mathrm{~N}$ (SRS coordinates)

Sample type: Normal

Sample matrix: Water

Constituent

RQ AQ B Result

Unit MDA

Method

Radionuclides

Tritium

$7.76 \mathrm{E}+02 \pm 3.90 \mathrm{E}+00 \mathrm{pCi} / \mathrm{mL} \quad 4.58 \mathrm{E}-01$

EPA906.0

SURVEY ID: FSP 22602

SAMPLE ID: 108902

Survey location: 48601E 73308N (SRS coordinates)

Sample type: Normal

Sample matrix: Water

Radionuclides

Tritium

$4.43 \mathrm{E}+02 \pm 4.11 \mathrm{E}+00 \mathrm{pCi} / \mathrm{mL} \quad 7.30 \mathrm{E}-01$

EPA906.0

SURVEY ID: FSP 23501

SAMPLE ID: 106522

Survey location: 48587E 72979N (SRS coordinates)

Sample type: Normal

Sample matrix: Water

Radionuclides

Tritium

$2.90 \mathrm{E}+02 \pm 2.83 \mathrm{E}+00 \mathrm{pCi} / \mathrm{mL} \quad 6.54 \mathrm{E}-01$

EPA906.0

SURVEY ID: FSP 23502

SAMPLE ID: 108903

Survey location: 48587E 72979N (SRS coordinates)

Sample type: Normal

Sample matrix: Water

\section{Radionuclides}

Tritium

$1.76 \mathrm{E}+02 \pm 2.55 \mathrm{E}+00 \mathrm{pCi} / \mathrm{mL} \quad 6.95 \mathrm{E}-01$

EPA906.0

SURVEY ID: FSP 23502A

Sample type: Duplicate

Radionuclides

Tritium

SURVEY ID: FSP 24101

Survey location: 48190E 72853N (SRS coordinates)

Sample type: Normal

Sample matrix: Water

Radionuclides

Tritium

$4.56 \mathrm{E}+02 \pm 8.94 \mathrm{E}+00 \quad \mathrm{pCi} / \mathrm{mL} \quad 1.60 \mathrm{E}+00$

SAMPLE ID: 108904

Associated sample: 108903

$1.77 \mathrm{E}+02 \pm 2.55 \mathrm{E}+00 \mathrm{pCi} / \mathrm{mL} \quad 6.89 \mathrm{E}-01$

EPA906.0

SAMPLE ID: 106521

EPA906.0 
SURVEY ID: FSP 24102 SAMPLE ID: 108968

Survey location: 48190E 72853N (SRS coordinates)

Sample type: Normal

Sample matrix: Water

Constituent

RQ AQ B Result

Unit MDA

Method

Radionuclides

Tritium

UI

$1.89 \mathrm{E}-01 \pm 3.95 \mathrm{E}-01 \quad \mathrm{pCi} / \mathrm{mL} \quad 6.69 \mathrm{E}-01$

EPA906.0

SURVEY ID: FSP 24901

SAMPLE ID: 106526

Survey location: 47905E 73107N (SRS coordinates)

Sample type: Normal

Sample matrix: Water

Radionuclides

Tritium

$6.78 \mathrm{E}+01 \pm 2.84 \mathrm{E}+00 \mathrm{pCi} / \mathrm{mL} \quad 1.50 \mathrm{E}+00$

EPA906.0

SURVEY ID: FSP 24902

SAMPLE ID: 108908

Survey location: 47905E 73107N (SRS coordinates)

Sample type: Normal

Sample matrix: Water

Radionuclides

Tritium

EPA906.0

SURVEY ID: FSP 25601

SAMPLE ID: 106525

Survey location: $47770 \mathrm{E} 73435 \mathrm{~N}$ (SRS coordinates)

Sample type: Normal

Sample matrix: Water

Radionuclides

Tritium .

SURVEY ID: FSP 25602

SAMPLE ID: 108909

Survey location: $47770 \mathrm{E} 73435 \mathrm{~N}$ (SRS coordinates)

Sample type: Normal

Sample matrix: Water

Radionuclides

Tritium

$2.85 \mathrm{E}+02 \pm 3.21 \mathrm{E}+00 \mathrm{pCi} / \mathrm{mL} \quad 6.88 \mathrm{E}-01$

EPA906.0

SURVEY ID: FSP 25602D

Sample type: Split

Radionuclides

Tritium
SAMPLE ID: 108910

Associated sample: 108909

$2.90 \mathrm{E}+02 \pm 1.94 \mathrm{E}+00 \quad \mathrm{pCi} / \mathrm{mL} \quad 1.17 \mathrm{E}+03$
$3 Q 1-6-1420$ 
SURVEY ID: FSP 27001

SAMPLE ID: 106524

Survey location: 47411E 72805N (SRS coordinates)

Sample type: Normal

Sample matrix: Water

Constituent

RQ AQ B Result

Unit MDA

Method

Radionuclides

Tritium

EPA906.0

SURVEY ID: FSP 27002

SAMPLE ID: 108907

Survey location: 47411E 72805N (SRS coordinates)

Sample type: Normal Sample matrix: Water

Radionuclides

Tritium

$4.17 \mathrm{E}+01 \pm 1.25 \mathrm{E}+00 \mathrm{pCi} / \mathrm{mL} \quad 6.56 \mathrm{E}-01$

EPA906.0

SURVEY ID: FSP 29001

SAMPLE ID: 106523

Survey location: $46865 \mathrm{E} 73160 \mathrm{~N}$ (SRS coordinates)

Sample type: Normal

Sample matrix: Water

Radionuclides

Tritium

$2.47 \mathrm{E}+01 \pm 7.63 \mathrm{E}-01 \quad \mathrm{pCi} / \mathrm{mL} \quad 4.82 \mathrm{E}-01$

EPA906.0

SURVEY ID: FSP 29002

SAMPLE ID: 108906

Survey location: $46865 \mathrm{E} 73160 \mathrm{~N}$ (SRS coordinates)

Sample type: Normal

Sample matrix: Water

Radionuclides

Tritium

$3.47 \mathrm{E}+01 \pm 1.16 \mathrm{E}+00 \mathrm{pCi} / \mathrm{mL} \quad 6.71 \mathrm{E}-01$

EPA906.0

SURVEY ID: HSP 0301

SAMPLE ID: 106559

Survey location: $56879 \mathrm{E} 70711 \mathrm{~N}$ (SRS coordinates)

Sample type: Normal

Sample matrix: Water

Radionuclides

Tritium

$7.80 \mathrm{E}+02 \pm 4.71 \mathrm{E}+00 \mathrm{pCi} / \mathrm{mL} \quad 6.80 \mathrm{E}-01$

EPA906.0

SURVEY ID: HSP 0302

SAMPLE ID: 108923

Survey location: 56879E 70711N (SRS coordinates)

Sample type: Normal

Sample matrix: Water

Radionuclides

Tritium

$1.74 \mathrm{E}+03 \pm 1.09 \mathrm{E}+01 \quad \mathrm{pCi} / \mathrm{mL} \quad 1.38 \mathrm{E}+00$

EPA906.0 
SURVEY ID: HSP 0401

SAMPLE ID: 106560

Survey location: $56819 \mathrm{E} 70710 \mathrm{~N}$ (SRS coordinates)

Sample type: Normal Sample matrix: Water

Constituent

RQ AQ B Result

Unit MDA

Method

Radionuclides

Tritium

SURVEY ID: HSP 0401A

Sample type: Duplicate

Radionuclides

Tritium
EPA906.0

Sample ID: 108924

SURVEY ID: HSP 0402

SAMPLE ID: 106561

Associated sample: 106560

Survey location: 56819E 70710N (SRS coordinates)

Sample type: Normal

Sample matrix: Water

Radionuclides

Tritium

$3.86 \mathrm{E}+02 \pm 4.48 \mathrm{E}+00 \quad \mathrm{pCi} / \mathrm{mL} \quad 1.03 \mathrm{E}+00$

EPA906.0

SURVEY ID: HSP 0801

SAMPLE ID: 106557

Survey location: $56990 \mathrm{E} 71005 \mathrm{~N}$ (SRS coordinates)

Sample type: Normal

Sample matrix: Water

Radionuclides

Tritium

$1.80 \mathrm{E}+03 \pm 1.10 \mathrm{E}+02 \mathrm{pCi} / \mathrm{mL} \quad 1.37 \mathrm{E}+01$

Tritium $1.93 \mathrm{E}+03 \pm 1.16 \mathrm{E}+02 \mathrm{pCi} / \mathrm{mL} \quad 1.41 \mathrm{E}+01$

EPA906.0 EPA906.0

SURVEY ID: HSP 0802

SAMPLE ID: 108925

Survey location: $56990 \mathrm{E} 71005 \mathrm{~N}$ (SRS coordinates)

Sample type: Normal

Sample matrix: Water

Radionuclides

Tritium

$1.19 \mathrm{E}+03 \pm 7.15 \mathrm{E}+00 \mathrm{pCi} / \mathrm{mL} \cdot 8.64 \mathrm{E}-01$

EPA906.0

SURVEY ID: HSP 1101

SAMPLE ID: 106558

Survey location: 57046E 71099N (SRS coordinates)

Sample type: Normal

Sample matrix: Water

Radionuclides

Tritium

$1.48 \mathrm{E}+02 \pm 1.73 \mathrm{E}+00 \mathrm{pCi} / \mathrm{mL} \quad 4.61 \mathrm{E}-01$

EPA906.0 
SURVEY ID: HSP 1301

SAMPLE ID: 106556

Survey location: $56878 \mathrm{E} 71056 \mathrm{~N}$ (SRS coordinates)

Sample type: Normal

Sample matrix: Water

Constituent

RQ AQ B Result

Unit MDA

Method

Radionuclides

Tritium

SURVEY ID: HSP 1302

SAMPLE ID: 108926

Survey location: 56878E 71056N (SRS coordinates)

Sample type: Normal

Sample matrix: Water

Radionuclides

Tritium

SURVEY ID: HSP 1501

SAMPLE ID: 106555

Survey location: $56791 \mathrm{E} 71085 \mathrm{~N}$ (SRS coordinates)

Sample type: Normal

Sample matrix: Water

Radionuclides

Tritium

SURVEY ID: HSP 1502

SAMPLE ID: 108927

Survey location: 56791E 71085N (SRS coordinates)

Sample type: Normal

Sample matrix: Water

Radionuclides

Tritium

$7.76 \mathrm{E}+02 \pm 5.01 \mathrm{E}+00 \mathrm{pCi} / \mathrm{mL} \quad 6.49 \mathrm{E}-01$

EPA906.0

SURVEY ID: HSP 2001

SAMPLE ID: 106554

Survey location: 56849E 71142N (SRS coordinates)

Sample type: Normal

Sample matrix: Water

Radionuclides

Tritium

$1.80 \mathrm{E}+02 \pm 7.19 \mathrm{E}+00 \mathrm{pCi} / \mathrm{mL} \quad 2.20 \mathrm{E}+00$

EPA906.0

SURVEY ID: HSP 2002

SAMPLE ID: 108928

Survey location: $56849 \mathrm{E} 71142 \mathrm{~N}$ (SRS coordinates)

Sample type: Normal

Sample matrix: Water

Radionuclides

Tritium

$2.28 \mathrm{E}+02 \pm 3.34 \mathrm{E}+00 \mathrm{pCi} / \mathrm{mL} \quad 9.65 \mathrm{E}-01$

EPA906.0 
SURVEY ID: HSP 2501

SAMPLE ID: 106553

Survey location: 56297E 70960N (SRS coordinates)

Sample type: Normal

Sample matrix: Water

Constituent

RQ AQ B Result

Unit MDA

Method

Radionuclides

Tritium

EPA906.0

SURVEY ID: HSP 2502

SAMPLE ID: 108929

Survey location: 56297E 70960N (SRS coordinates)

Sample type: Normal

Sample matrix: Water

Radionuclides

Tritium

$7.99 \mathrm{E}+02 \pm 6.62 \mathrm{E}+00 \mathrm{pCi} / \mathrm{mL} \quad 1.10 \mathrm{E}+00$

EPA906.0

SURVEY ID: HSP 2901

SAMPLE ID: 106552

Survey location: $56257 \mathrm{E} 71278 \mathrm{~N}$ (SRS coordinates)

Sample type: Normal

Sample matrix: Water

Radionuclides

Tritium

$9.77 \mathrm{E}+01 \pm 1.39 \mathrm{E}+00 \mathrm{pCi} / \mathrm{mL} \quad 4.44 \mathrm{E}-01$

EPA906.0

SURVEY ID: HSP 2902

SAMPLE ID: 108930

Survey location: $56257 \mathrm{E} 71278 \mathrm{~N}$ (SRS coordinates)

Sample type: Normal

Sample matrix: Water

Radionuclides

Tritium

$7.04 \mathrm{E}+01 \pm 1.49 \mathrm{E}+00 \mathrm{pCi} / \mathrm{mL} \quad 6.00 \mathrm{E}-01$

EPA906.0

SURVEY ID: HSP 3401

SAMPLE ID: 106551

Survey location: 56193E 71698N (SRS coordinates)

Sample type: Normal

Sample matrix: Water

Radionuclides

Tritium

$3.41 \mathrm{E}+02 \pm 4.30 \mathrm{E}+00 \mathrm{pCi} / \mathrm{mL} \quad 1.28 \mathrm{E}+00$

EPA906.0

SURVEY ID: HSP 4301

SAMPLE ID: 106544

Survey location: 55722E 71644N (SRS coordinates)

Sample type: Normal

Sample matrix: Water

Radionuclides

Tritium

$2.31 \mathrm{E}+03 \pm 1.47 \mathrm{E}+02 \mathrm{pCi} / \mathrm{mL} \quad 1.66 \mathrm{E}+01$

EPA906.0 
SURVEY ID: HSP 4601

SAMPLE ID: 106546

Survey location: $56052 \mathrm{E} 71621 \mathrm{~N}$ (SRS coordinates)

Sample type: Normal Sample matrix: Water

Constituent

RQ AQ B Result

Unit MDA

Method

Radionuclides

Tritium

SURVEY ID: HSP 4602

SAMPLE ID: 108936

Survey location: $56052 \mathrm{E} 71621 \mathrm{~N}$ (SRS coordinates)

Sample type: Normal

Sample matrix: Water

\section{Radionuclides}

Tritium

SURVEY ID: HSP 4901

SAMPLE ID: 106548

Survey location: 55987E 71389N (SRS coordinates)

Sample type: Normal

Sample matrix: Water

\section{Radionuclides}

Tritium

SURVEY ID: HSP 4902

SAMPLE ID: 108935

Survey location: 55987E 71389N (SRS coordinates)

Sample type: Normal

Sample matrix: Water

Radionuclides

Tritium

$1.06 \mathrm{E}+03 \pm 9.36 \mathrm{E}+00 \mathrm{pCi} / \mathrm{mL} \quad 1.66 \mathrm{E}+00$

EPA906.0

SURVEY ID: HSP 5201

SAMPLE ID: 106547

Survey location: 55743E 71413N (SRS coordinates)

Sample type: Normal

Sample matrix: Water

Radionuclides

Tritium

$7.66 \mathrm{E}+03 \pm 3.69 \mathrm{E}+02 \mathrm{pCi} / \mathrm{mL} \quad 2.60 \mathrm{E}+01$

EPA906.0

SURVEY ID: HSP 5202

SAMPLE ID: 108934

Survey location: 55743E 71413N (SRS coordinates)

Sample type: Normal

Sample matrix: Water

Radionuclides

Tritium 
SURVEY ID: HSP 5202A

Sample type: Duplicate

Constituent

Radionuclides

Tritium

SURVEY ID: HSP 5701

Survey location: 55516E 71567N (SRS coordinates)

Sample type: Normal

Sample matrix: Water

Radionuclides

Tritium

$3.34 \mathrm{E}+02 \pm 2.96 \mathrm{E}+00 \quad \mathrm{pCi} / \mathrm{mL} \quad 6.20 \mathrm{E}-01$

SAMPLE ID: 106550

SURVEY ID: HSP 5701D

Associated sample: 106549

Sample type: Split

Radionuclides

Tritium

SURVEY ID: HSP 5702

Survey location: 55516E 71567N (SRS coordinates)

Sample type: Normal

Sample matrix: Water

Radionuclides

Tritium

$1.08 \mathrm{E}+03 \pm 6.41 \mathrm{E}+00 \mathrm{pCi} / \mathrm{mL} \quad 7.60 \mathrm{E}-01$

SAMPLE ID: 106540

SURVEY ID: HSP 6001

Survey location: $55190 \mathrm{E} 71629 \mathrm{~N}$ (SRS coordinates)

Sample type: Normal

Sample matrix: Water

Radionuclides

Tritium

$1.26 \mathrm{E}+03 \pm 7.75 \mathrm{E}+01 \quad \mathrm{pCi} / \mathrm{mL} \quad 1.06 \mathrm{E}+01$

SAMPLE ID: 106541

SURVEY ID: HSP 6401

Survey location: $54768 \mathrm{E} 71846 \mathrm{~N}$ (SRS coordinates)

Sample type: Normal

Sample matrix: Water

\section{Radionuclides}

Tritium

$1.96 \mathrm{E}+01 \pm 6.64 \mathrm{E}-01 \quad \mathrm{pCi} / \mathrm{mL} \quad 4.47 \mathrm{E}-01$
EPA906.0

3Q1-6-1420

EPA906.0

EPA906.0

EPA906.0 
SURVEY ID: HSP 6402

SAMPLE ID: 108939

Survey location: $54768 \mathrm{E} 71846 \mathrm{~N}$ (SRS coordinates)

Sample type: Normal

Sample matrix: Water

Constituent

RQ AQ B Result

Unit MDA

Method

Radionuclides

Tritium

$2.04 \mathrm{E}+01 \pm 8.53 \mathrm{E}-01 \quad \mathrm{pCi} / \mathrm{mL} \quad 6.01 \mathrm{E}-01$

EPA906.0

SURVEY ID: HSP 7101

SAMPLE ID: 106563

Survey location: $54937 \mathrm{E} 71588 \mathrm{~N}$ (SRS coordinates)

Sample type: Normal

Sample matrix: Water

Radionuclides

Tritium

SURVEY ID: HSP 7102

SAMPLE ID: 108940

Survey location: $54937 \mathrm{E} 71588 \mathrm{~N}$ (SRS coordinates)

Sample type: Normal

Sample matrix: Water

Radionuclides

Tritium

SURVEY ID: HSP 7601

SAMPLE ID: 106543

Survey location: 54571E 71494N (SRS coordinates)

Sample type: Normal

Sample matrix: Water

Radionuclides

Tritium

$1.52 \mathrm{E}+02 \pm 1.73 \mathrm{E}+00 \mathrm{pCi} / \mathrm{mL} \quad 4.50 \mathrm{E}-01$

EPA906.0

SURVEY ID: HSP 7602

SAMPLE ID: 108941

Survey location: $54571 \mathrm{E} 71494 \mathrm{~N}$ (SRS coordinates)

Sample type: Normal

Sample matrix: Water

Radionuclides

Tritium

$4.10 \mathrm{E}+02 \pm 3.56 \mathrm{E}+00 \mathrm{pCi} / \mathrm{mL} \quad 6.17 \mathrm{E}-01$

EPA906.0

SURVEY ID: HSP 9701

SAMPLE ID: 106565

Survey location: $54029 \mathrm{E} 72371 \mathrm{~N}$ (SRS coordinates)

Sample type: Normal

Sample matrix: Water

Radionuclides

Tritium

$1.44 \mathrm{E}+03 \pm 9.22 \mathrm{E}+01 \quad \mathrm{pCi} / \mathrm{mL} \quad 1.19 \mathrm{E}+01$

EPA906.0 
SURVEY ID: HSP 9702 SAMPLE ID: 108956

Survey location: $54029 \mathrm{E} 72371 \mathrm{~N}$ (SRS coordinates)

Sample type: Normal

Sample matrix: Water

Constituent

RQ AQ B Result

Unit MDA

Method

Radionuclides

Tritium

EPA906.0

SURVEY ID: HSP 9702A

SAMPLE ID: 108957

Sample type: Duplicate

Associated sample: 108956

Radionuclides

Tritium

$1.99 \mathrm{E}+03 \pm 7.78 \mathrm{E}+00 \mathrm{pCi} / \mathrm{mL} \quad 6.12 \mathrm{E}-01$

Tritium

SURVEY ID: HSP 10301

SAMPLE ID: 106564

Survey location: 53665E 72448N (SRS coordinates)

Sample type: Normal

Sample matrix: Water

Radionuclides

Tritium

SURVEY ID: HSP 10302

SAMPLE ID: 108955

Survey location: 53665E 72448N (SRS coordinates)

Sample type: Normal

Sample matrix: Water

\section{Radionuclides}

Tritium

$1.66 \mathrm{E}+03 \pm 5.76 \mathrm{E}+00 \mathrm{pCi} / \mathrm{mL} \quad 4.77 \mathrm{E} \cdot 01$

EPA906.0 


\section{D.4 Water Results Sorted by Analyte}

Table D.8. Water Results Sorted by Analyte

ANALYTE: Tritium

Analytical Group: Radionuclides

\begin{tabular}{|c|c|c|c|c|c|c|c|c|c|}
\hline Surv & vey ID & Sample ID & $\mathbf{R Q}$ & B & Result & Unit & MDA & Method & $\mathbf{A Q}$ \\
\hline FHB & 0101 & 106500 & & & $1.02 \mathrm{E}+02 \pm 2.20 \mathrm{E}+00$ & $\mathrm{pCi} / \mathrm{mL}$ & $1.06 \mathrm{E}+00$ & EPA906.0 & \\
\hline FHB & 0201 & 106501 & & & $1.54 \mathrm{E}+01 \pm 6.42 \mathrm{E}-01$ & $\mathrm{pCi} / \mathrm{mL}$ & 5.04E-01 & EPA906.0 & \\
\hline FHB & $0201 \mathrm{D}$ & 106502 & UI & & $3.72 \mathrm{E}+00 \pm 1.49 \mathrm{E}+01$ & $\mathrm{pCi} / \mathrm{mL}$ & $5.87 \mathrm{E}+04$ & $3 Q 1-6-1420$ & \\
\hline FHB & $0201 D$ & 106502 & UI & & $4.84 \mathrm{E}+00 \pm 1.49 \mathrm{E}+01$ & $\mathrm{pCi} / \mathrm{mL}$ & $5.87 \mathrm{E}+04$ & $3 Q 1-6-1420$ & \\
\hline FHB & 0202 & 108943 & & & $1.63 \mathrm{E}+01 \pm 6.45 \mathrm{E}-01$ & $\mathrm{pCi} / \mathrm{mL}$ & $4.94 \mathrm{E}-01$ & EPA906.0 & \\
\hline FHB & 0301 & 106512 & & & $1.15 \mathrm{E}+02 \pm 1.99 \mathrm{E}+00$ & $\mathrm{pCi} / \mathrm{mL}$ & $7.89 \mathrm{E}-01$ & EPA906.0 & \\
\hline FHB & 0302 & 108953 & & & $8.71 \mathrm{E}+01 \pm 2.69 \mathrm{E}+00$ & $\mathrm{pCi} / \mathrm{mL}$ & $1.72 \mathrm{E}+00$ & EPA906.0 & \\
\hline FHB & 0401 & 106513 & & & $1.15 \mathrm{E}+02 \pm 1.64 \mathrm{E}+00$ & $\mathrm{pCi} / \mathrm{mL}$ & $5.38 \mathrm{E} \cdot 01$ & EPA906.0 & \\
\hline FHB & 0402 & 108954 & & & $2.47 \mathrm{E}+02 \pm 2.37 \mathrm{E}+00$ & $\mathrm{pCi} / \mathrm{mL}$ & 5.35E-01 & EPA906.0 & \\
\hline FHB & 0501 & 106515 & & & $4.06 \mathrm{E}+02 \pm 2.99 \mathrm{E}+00$ & $\mathrm{pCi} / \mathrm{mL}$ & 5.17E-01 & EPA906.0 & \\
\hline FHB & 0502 & 108960 & & & $4.96 \mathrm{E}+02 \pm 3.28 \mathrm{E}+00$ & $\mathrm{pCi} / \mathrm{mL}$ & $5.16 \mathrm{E}-01$ & EPA906.0 & \\
\hline FHB & 0601 & 106514 & & & $2.07 \mathrm{E}+02 \pm 2.01 \mathrm{E}+00$ & $\mathrm{pCi} / \mathrm{mL}$ & $4.47 \mathrm{E}-01$ & EPA906.0 & \\
\hline FHB & 0602 & 108958 & & & $2.11 \mathrm{E}+02 \pm 2.67 \mathrm{E}+00$ & $\mathrm{pCi} / \mathrm{mL}$ & 6.42E-01 & EPA906.0 & \\
\hline FHB & $0602 \mathrm{D}$ & 108959 & & & $2.12 \mathrm{E}+02 \pm 1.62 \mathrm{E}+00$ & $\mathrm{pCi} / \mathrm{mL}$ & $1.17 \mathrm{E}+03$ & $3 Q 1-6-1420$ & \\
\hline FHB & $0602 \mathrm{D}$ & 108959 & & & $2.10 \mathrm{E}+02 \pm 1.61 \mathrm{E}+00$ & $\mathrm{pCi} / \mathrm{mL}$ & $1.17 \mathrm{E}+03$ & $3 Q 1-6-1420$ & \\
\hline FHB & 0801 & 106516 & & & $1.58 \mathrm{E}+02 \pm 1.78 \mathrm{E}+00$ & $\mathrm{pCi} / \mathrm{mL}$ & $4.58 \mathrm{E}-01$ & EPA906.0 & \\
\hline FHB & 0801 & 106516 & & & $1.55 \mathrm{E}+02 \pm 1.76 \mathrm{E}+00$ & $\mathrm{pCi} / \mathrm{mL}$ & $4.58 \mathrm{E}-01$ & EPA906.0 & \\
\hline FHB & 0802 & 108961 & & & $2.00 \mathrm{E}+02 \pm 2.09 \mathrm{E}+00$ & $\mathrm{pCi} / \mathrm{mL}$ & $5.14 \mathrm{E}-01$ & EPA906.0 & \\
\hline FHB & 1201 & 106506 & & & $1.50 \mathrm{E}+04 \pm 5.52 \mathrm{E}+02$ & $\mathrm{pCi} / \mathrm{mL}$ & $3.00 \mathrm{E}+01$ & EPA906.0 & \\
\hline FHB & 1202 & 108952 & & & $1.85 \mathrm{E}+04 \pm 1.82 \mathrm{E}+02$ & $\mathrm{pCi} / \mathrm{mL}$ & $1.17 \mathrm{E}+05$ & 3Q1-6-1420 & \\
\hline FHB & 1301 & 106505 & & & $8.12 \mathrm{E}+03 \pm 3.91 \mathrm{E}+02$ & $\mathrm{pCi} / \mathrm{mL}$ & $2.76 \mathrm{E}+01$ & EPA906.0 & \\
\hline FHB & 1302 & 108950 & & & $7.19 \mathrm{E}+03 \pm 4.82 \mathrm{E}+01$ & $\mathrm{pCi} / \mathrm{mL}$ & $1.17 E+04$ & 3Q1-6-1420 & \\
\hline FHB & 1401 & 106507 & & & $3.07 \mathrm{E}+02 \pm 2.43 \mathrm{E}+00$ & $\mathrm{pCi} / \mathrm{mL}$ & $4.42 \mathrm{E}-01$ & EPA906.0 & \\
\hline FHB & 1402 & 108951 & & & $2.09 \mathrm{E}+02 \pm 2.04 \mathrm{E}+00$ & $\mathrm{pCi} / \mathrm{mL}$ & $4.68 \mathrm{E}-01$ & EPA906.0 & \\
\hline FHB & 1601 & 106510 & & & $2.40 \mathrm{E}+02 \pm 2.34 \mathrm{E}+00$ & $\mathrm{pCi} / \mathrm{mL}$ & 5.31E-01 & EPA906.0 & \\
\hline FHB & 1602 & 108944 & & & $2.78 \mathrm{E}+02 \pm 2.39 \mathrm{E}+00$ & $\mathrm{pCi} / \mathrm{mL}$ & $4.87 \mathrm{E}-01$ & EPA906.0 & \\
\hline FHB & 1701 & 106509 & & & $1.04 \mathrm{E}+04 \pm 6.62 \mathrm{E}+02$ & $\mathrm{pCi} / \mathrm{mL}$ & $9.55 \mathrm{E}+01$ & EPA906.0 & \\
\hline FHB & 1702 & 108947 & & & $8.83 E+03 \pm 1.20 E+02$ & $\mathrm{pCi} / \mathrm{mL}$ & $1.17 \mathrm{E}+05$ & $3 Q 1-6-1420$ & \\
\hline FHB & 1801 & 106508 & & & $2.02 \mathrm{E}+04 \pm 6.01 \mathrm{E}+02$ & $\mathrm{pCi} / \mathrm{mL}$ & $2.62 \mathrm{E}+01$ & EPA906.0 & \\
\hline FHB & 1802 & 108948 & & & $1.91 \mathrm{E}+04 \pm 1.89 \mathrm{E}+02$ & $\mathrm{pCi} / \mathrm{mL}$ & $1.17 \mathrm{E}+05$ & $3 Q 1-6-1420$ & \\
\hline FHB & 1901 & 106504 & & & $5.63 \mathrm{E}+03 \pm 3.69 \mathrm{E}+02$ & $\mathrm{pCi} / \mathrm{mL}$ & $6.67 \mathrm{E}+01$ & EPA906.0 & \\
\hline FHB & 2001 & 106503 & & & $2.41 \mathrm{E}+01 \pm 7.70 \mathrm{E}-01$ & $\mathrm{pCi} / \mathrm{mL}$ & $5.00 \mathrm{E}-01$ & EPA906.0 & \\
\hline FHB & 2001A & 106542 & & & $2.35 \mathrm{E}+01 \pm 7.67 \mathrm{E}-01$ & $\mathrm{pCi} / \mathrm{mL}$ & $5.07 \mathrm{E}-01$ & EPA906.0 & \\
\hline FHB & 2002 & 108942 & & & $2.18 \mathrm{E}+01 \pm 7.08 \mathrm{E}-01$ & $\mathrm{pCi} / \mathrm{mL}$ & 4.70E-01 & EPA906.0 & \\
\hline FMC & $1 F 01$ & 106539 & & & $4.56 \mathrm{E}+02 \pm 2.97 \mathrm{E}+00$ & $\mathrm{pCi} / \mathrm{mL}$ & $4.47 \mathrm{E}-01$ & EPA906.0 & \\
\hline FMC & $1 F 02$ & 108964 & & & $5.20 \mathrm{E}+02 \pm 3.22 \mathrm{E}+00$ & $\mathrm{pCi} / \mathrm{mL}$ & $4.75 \mathrm{E}-01$ & EPA906.0 & \\
\hline FMC & $1 \mathrm{H} 01$ & 106562 & & & $2.89 \mathrm{E}+01 \pm 1.23 \mathrm{E}+00$ & $\mathrm{pCi} / \mathrm{mL}$ & 7.10E-01 & EPA906.0 & \\
\hline FMC & $1 \mathrm{H02}$ & 108962 & & & $3.46 \mathrm{E}+01 \pm 8.66 \mathrm{E}-01$ & $\mathrm{pCi} / \mathrm{mL}$ & $4.70 \mathrm{E}-01$ & EPA906.0 & \\
\hline FMC & $2 \mathrm{H01}$ & 106567 & & & $8.82 \mathrm{E}+01 \pm 1.33 \mathrm{E}+00$ & $\mathrm{pCi} / \mathrm{mL}$ & 4.53E-01 & EPA906.0 & \\
\hline FMC & 2H01D & 106568 & & & $8.58 \mathrm{E}+01 \pm 1.61 \mathrm{E}+01$ & $\mathrm{pCi} / \mathrm{mL}$ & $5.87 \mathrm{E}+04$ & $3 Q 1-6-1420$ & \\
\hline FMC & $2 \mathrm{HO2}$ & 108963 & & & $7.55 \mathrm{E}+01 \pm 1.25 \mathrm{E}+00$ & $\mathrm{pCi} / \mathrm{mL}$ & $4.73 \mathrm{E}-01$ & EPA906.0 & \\
\hline FMC & $2 \mathrm{H} 02 \mathrm{D}$ & 108966 & & & $8.83 \mathrm{E}+01 \pm 1.07 \mathrm{E}+00$ & $\mathrm{pCi} / \mathbf{m L}$ & $1.17 \mathrm{E}+03$ & $3 Q 1-6-1420$ & \\
\hline FSP & 0201 & 106528 & & & $6.12 \mathrm{E}+02 \pm 3.42 \mathrm{E}+00$ & $\mathrm{pCi} / \mathrm{mL}$ & $4.44 \mathrm{E}-01$ & EPA906.0 & \\
\hline FSP & 0201A & 106529 & & & $6.13 \mathrm{E}+02 \pm 3.43 \mathrm{E}+00$ & $\mathrm{pCi} / \mathrm{mL}$ & $4.44 \mathrm{E}-01$ & EPA906.0 & \\
\hline FSP & 0202 & 108911 & & & $7.79 \mathrm{E}+02 \pm 5.13 \mathrm{E}+00$ & $\mathrm{pCi} / \mathrm{mL}$ & $6.50 \mathrm{E}-01$ & EPA906.0 & \\
\hline FSP & 0701 & 106527 & & & $8.09 \mathrm{E}+02 \pm 6.55 \mathrm{E}+00$ & $\mathrm{pCi} / \mathrm{mL}$ & $1.06 \mathrm{E}+00$ & EPA906.0 & \\
\hline FSP & 0702 & 108912 & & & $1.01 \mathrm{E}+03 \pm 6.12 \mathrm{E}+00$ & $\mathrm{pCi} / \mathrm{mL}$ & 7.11E-01 & EPA906.0 & \\
\hline FSP & 1201 & 106530 & & & $1.95 \mathrm{E}+01 \pm 6.96 \mathrm{E}-01$ & $\mathrm{pCi} / \mathrm{mL}$ & 4.91E-01 & EPA906.0 & \\
\hline FSP & 1201 & 106530 & & & $1.87 \mathrm{E}+01 \pm 7.18 \mathrm{E}-01$ & $\mathrm{pCi} / \mathrm{mL}$ & 5.35E-01 & EPA906.0 & \\
\hline FSP & 1202 & 108913 & & & $6.98 \mathrm{E}+01 \pm 1.59 \mathrm{E}+00$ & $\mathrm{pCi} / \mathrm{mL}$ & $6.61 \mathrm{E}-01$ & EPA906.0 & \\
\hline FSP & 1401 & 106534 & & & $1.08 \mathrm{E}+01 \pm 7.45 \mathrm{E}-01$ & $\mathrm{pCi} / \mathrm{mL}$ & 7.82E-01 & EPA906.0 & \\
\hline FSP & 1402 & 108921 & & & $5.08 \mathrm{E}+01 \pm 1.28 \mathrm{E}+00$ & $\mathrm{pCi} / \mathrm{mL}$ & $6.00 \mathrm{E}-01$ & EPA906.0 & \\
\hline
\end{tabular}

$1.02 \mathrm{E}+02 \pm 2.20 \mathrm{E}+00$

$54 \mathrm{E}+01 \pm 6.42 \mathrm{E}-01$

$163 \mathrm{E}+01+6.45 \mathrm{E}-01$

$2.47 \mathrm{E}+02+2.37 \mathrm{E}+00$

$2.11 \mathrm{E}+02 \pm 2.67 \mathrm{E}+00$

$2.12 \mathrm{E}+02 \pm 1.62 \mathrm{E}+00$

$1.85 \mathrm{E}+04 \pm 1.82 \mathrm{E}+02$

$1.04 \mathrm{E}+04 \pm 6.62 \mathrm{E}+02$

$8.83 \mathrm{E}+03 \pm 1.20 \mathrm{E}+02$

(2)

89E+02

$2.18 \mathrm{E}+01 \pm 7.08 \mathrm{E}-01$

$4.56 \mathrm{E}+02 \pm 2.97 \mathrm{E}+00$

$7.55 \mathrm{E}+01 \pm 1.25 \mathrm{E}+00$

$8.83 \mathrm{E}+01 \pm 1.07 \mathrm{E}+00$

.

$1.95 \mathrm{E}+01+6.96 \mathrm{E}-01$

$1.87 \mathrm{E}+01 \pm 7.18 \mathrm{E}-01$

$1.08 \mathrm{E}+01 \pm 7.45 \mathrm{E}-0$

$5.08 \mathrm{E}+01 \pm 1.28 \mathrm{E}+00$
pCi/mL 5.04E-01 $\mathrm{pCi} / \mathrm{mL} \quad 5.87 \mathrm{E}+04$ Ci/mL 5.16E-0 4.47E-0 $\mathrm{pCi} / \mathrm{mL} \quad 4.58 \mathrm{E}-0$ $\mathrm{Ci} / \mathrm{mL}, 1.17 \mathrm{E}+05$ $\mathrm{Ci} / \mathrm{mL} 2.76 \mathrm{E}+0$ $1.17 \mathrm{E}+04$ mL 4.42E-01 Ci/mL 955E+01 pi/mL $1.17 \mathrm{E}+05$ $2.62 \mathrm{E}+01$ $\mathrm{pCi} / \mathrm{mL} \quad 4.70 \mathrm{E}-01$ $\mathrm{pCi} / \mathrm{mL} \quad 4.47 \mathrm{E}-01$ 4.75E-01 $\mathrm{pCi} / \mathrm{mL} \quad 7.10 \mathrm{E}-01$ $\mathrm{pCi} / \mathrm{mL} \quad 4.70 \mathrm{E}-01$ pCi/mL 4.53E-01 mL 5.87E+04 $\mathrm{pCi} / \mathrm{mL} \quad 4.73 \mathrm{E}-01$ $\mathrm{pCi} / \mathrm{mL}$ 1.17E+03 4.44E-0 $\mathrm{pCi} / \mathrm{mL} \quad$ 4.44E-01 $\mathrm{pCi} / \mathrm{mL} \quad 6.50 \mathrm{E}-01$ $\mathrm{pCi} / \mathrm{mL} \quad 1.06 \mathrm{E}+00$ $\mathrm{mL}$ 7.11E-0 $\mathrm{pCi} / \mathrm{mL} \quad 4.91 \mathrm{E}-01$ $\mathrm{pCi} / \mathrm{mL}$ 5.35E-01 $\mathrm{pCi} / \mathrm{mL} \quad 7.82 \mathrm{E}-01$ pCi/mL 6.00E-01 
ANALYTE: Tritium (continued)

\begin{tabular}{|c|c|c|c|c|c|c|c|}
\hline Survey ID & Sample ID & $\mathbf{R Q}$ & $\mathbf{B}$ & Result & Unit & MDA & Method \\
\hline FSP 1901 & 106531 & & & $4.53 \mathrm{E}+03 \pm 3.07 \mathrm{E}+02$ & $\mathrm{pCi} / \mathrm{mL}$ & $3.06 \mathrm{E}+01$ & EPA906.0 \\
\hline FSP 1902 & 108914 & & & $4.27 \mathrm{E}+03 \pm 3.17 \mathrm{E}+01$ & $\mathrm{pCi} / \mathrm{mL}$ & $1.17 \mathrm{E}+04$ & $3 Q 1-6-1420$ \\
\hline FSP 2601 & 106533 & & & $7.74 \mathrm{E}+03 \pm 3.99 \mathrm{E}+02$ & $\mathrm{pCi} / \mathrm{mL}$ & $3.04 \mathrm{E}+01$ & EPA906.0 \\
\hline FSP 2602 & 108915 & & & $3.98 \mathrm{E}+03 \pm 3.06 \mathrm{E}+01$ & $\mathrm{pCi} / \mathrm{mL}$ & $1.17 \mathrm{E}+04$ & $3 Q 1-6-1420$ \\
\hline FSP 2602A & 108916 & & & $4.02 \mathrm{E}+03 \pm 3.09 \mathrm{E}+01$ & $\mathrm{pCi} / \mathrm{mL}$ & $1.17 \mathrm{E}+04$ & $3 Q 1-6-1420$ \\
\hline FSP 2602A & 108916 & & & $3.92 \mathrm{E}+03 \pm 3.00 \mathrm{E}+01$ & $\mathrm{pCi} / \mathrm{mL}$ & $1.17 \mathrm{E}+04$ & $3 Q 1-6-1420$ \\
\hline FSP 3201 & 106532 & & & $3.27 \mathrm{E}+01 \pm 8.27 \mathrm{E}-01$ & $\mathrm{pCi} / \mathrm{mL}$ & $4.42 \mathrm{E}-01$ & EPA906.0 \\
\hline FSP 3202 & 108917 & & & $2.32 \mathrm{E}+02 \pm 2.83 \mathrm{E}+00$ & $\mathrm{pCi} / \mathrm{mL}$ & $6.56 \mathrm{E}-01$ & EPA906.0 \\
\hline FSP 3202 & 108917 & & & $2.32 \mathrm{E}+02 \pm 2.83 \mathrm{E}+00$ & $\mathrm{pCi} / \mathrm{mL}$ & $6.56 \mathrm{E}-01$ & EPA906.0 \\
\hline FSP 3401 & 106566 & & & $6.77 \mathrm{E}+02 \pm 4.29 \mathrm{E}+00$ & $\mathrm{pCi} / \mathrm{mL}$ & $6.49 \mathrm{E}-01$ & EPA906.0 \\
\hline FSP 3402 & 108967 & & & $2.91 \mathrm{E}+03 \pm 1.04 \mathrm{E}+01$ & $\mathrm{pCi} / \mathrm{mL}$ & $1.44 \mathrm{E}+00$ & EPA906.0 \\
\hline FSP 3402 & 108967 & & & $2.92 \mathrm{E}+03 \pm 1.04 \mathrm{E}+01$ & $\mathrm{pCi} / \mathrm{mL}$ & $1.43 \mathrm{E}+00$ & EPA906.0 \\
\hline FSP 3501 & 106537 & & & $5.26 \mathrm{E}+03 \pm 3.28 \mathrm{E}+02$ & $\mathrm{pCi} / \mathrm{mL}$ & $3.02 \mathrm{E}+01$ & EPA906.0 \\
\hline FSP 3502 & 108918 & & & $7.15 \mathrm{E}+03 \pm 7.86 \mathrm{E}+01$ & $\mathrm{pCi} / \mathrm{mL}$ & $5.87 \mathrm{E}+04$ & $3 Q 1-6-1420$ \\
\hline FSP 4001 & 106536 & & & $4.60 \mathrm{E}+03 \pm 3.07 \mathrm{E}+02$ & $\mathrm{pCi} / \mathrm{mL}$ & $6.64 \mathrm{E}+01$ & EPA906.0 \\
\hline FSP 4002 & 108919 & & & $4.64 \mathrm{E}+03 \pm 3.42 \mathrm{E}+01$ & $\mathrm{pCi} / \mathrm{mL}$ & $1.17 \mathrm{E}+04$ & $3 Q 1-6-1420$ \\
\hline FSP 4701 & 106535 & & & $1.53 \mathrm{E}+01 \pm 7.04 \mathrm{E}-01$ & $\mathrm{pCi} / \mathrm{mL}$ & 5.35E-01 & EPA906.0 \\
\hline FSP 4702 & 108920 & & & $2.00 \mathrm{E}+01 \pm 8.55 \mathrm{E}-01$ & $\mathrm{pCi} / \mathrm{mL}$ & $6.13 \mathrm{E}-01$ & EPA906.0 \\
\hline FSP 5601 & 106538 & & & $7.38 \mathrm{E}+00 \pm 4.54 \mathrm{E}-01$ & $\mathrm{pCi} / \mathrm{mL}$ & 4.44E-01 & EPA906.0 \\
\hline FSP 5602 & 108922 & & & $7.05 \mathrm{E}+00 \pm 5.94 \mathrm{E}-01$ & $\mathrm{pCi} / \mathrm{mL}$ & 6.33E-01 & EPA906.0 \\
\hline FSP 20401 & 106517 & & & $2.56 \mathrm{E}+03 \pm 1.62 \mathrm{E}+02$ & $\mathrm{pCi} / \mathrm{mL}$ & $1.84 \mathrm{E}+01$ & EPA906.0 \\
\hline FSP 20402 & 108900 & & & $2.88 \mathrm{E}+03 \pm 2.43 \mathrm{E}+01$ & $\mathrm{pCi} / \mathrm{mL}$ & $1.17 \mathrm{E}+04$ & $3 Q 1-6-1420$ \\
\hline FSP 21301 & 106518 & & & $1.79 \mathrm{E}+03 \pm 1.11 \mathrm{E}+02$ & $\mathrm{pCi} / \mathrm{mL}$ & $1.39 \mathrm{E}+01$ & EPA906.0 \\
\hline FSP 21302 & 108901 & & & $2.20 \mathrm{E}+03 \pm 2.04 \mathrm{E}+01$ & $\mathrm{pCi} / \mathrm{mL}$ & $1.17 \mathrm{E}+04$ & $3 Q 1-6-1420$ \\
\hline FSP 22001 & 106520 & & & $6.98 \mathrm{E}+02 \pm 3.93 \mathrm{E}+00$ & $\mathrm{pCi} / \mathrm{mL}$ & 5.24E-01 & EPA906.0 \\
\hline FSP 22002 & 108905 & & & $9.55 \mathrm{E}+02 \pm 5.96 \mathrm{E}+00$ & $\mathrm{pCi} / \mathrm{mL}$ & 7.15E-01 & EPA906.0 \\
\hline FSP 22601 & 106519 & & & $7.76 \mathrm{E}+02 \pm 3.90 \mathrm{E}+00$ & $\mathrm{pCi} / \mathrm{mL}$ & 4.58E-01 & EPA906.0 \\
\hline FSP 22602 & 108902 & & & $4.43 \mathrm{E}+02 \pm 4.11 \mathrm{E}+00$ & $\mathrm{pCi} / \mathrm{mL}$ & 7.30E-01 & EPA906.0 \\
\hline FSP 23501 & 106522 & & & $2.90 \mathrm{E}+02 \pm 2.83 \mathrm{E}+00$ & $\mathrm{pCi} / \mathrm{mL}$ & 6.54E-01 & EPA906.0 \\
\hline FSP 23502 & 108903 & & & $1.76 \mathrm{E}+02 \pm 2.55 \mathrm{E}+00$ & $\mathrm{pCi} / \mathrm{mL}$ & $6.95 \mathrm{E}-01$ & EPA906.0 \\
\hline FSP 23502A & 108904 & & & $1.77 \mathrm{E}+02 \pm 2.55 \mathrm{E}+00$ & $\mathrm{pCi} / \mathrm{mL}$ & $6.89 \mathrm{E}-01$ & EPA906.0 \\
\hline FSP 24101 & 106521 & & & $4.56 \mathrm{E}+02 \pm 8.94 \mathrm{E}+00$ & $\mathrm{pCi} / \mathrm{mL}$ & $1.60 \mathrm{E}+00$ & EPA906.0 \\
\hline FSP 24102 & 108968 & UI & & $1.89 \mathrm{E}-01 \pm 3.95 \mathrm{E}-01$ & $\mathrm{pCi} / \mathrm{mL}$ & $6.69 \mathrm{E}-01$ & EPA906.0 \\
\hline FSP 24901 & 106526 & & & $6.78 \mathrm{E}+01 \pm 2.84 \mathrm{E}+00$ & $\mathrm{pCi} / \mathrm{mL}$ & $1.50 \mathrm{E}+00$ & EPA906.0 \\
\hline FSP 24902 & 108908 & & & $3.45 \mathrm{E}+02 \pm 4.61 \mathrm{E}+00$ & $\mathrm{pCi} / \mathrm{mL}$ & $1.17 \mathrm{E}+00$ & EPA906.0 \\
\hline FSP 25601 & 106525 & & & $3.07 \mathrm{E}+02 \pm 2.45 \mathrm{E}+00$ & $\mathrm{pCi} / \mathrm{mL}$ & 4.53E-01 & EPA906.0 \\
\hline FSP 25602 & 108909 & & & $2.85 \mathrm{E}+02 \pm 3.21 \mathrm{E}+00$ & $\mathrm{pCi} / \mathrm{mL}$ & $6.88 \mathrm{E}-01$ & EPA906.0 \\
\hline FSP 25602D & 108910 & & & $2.90 \mathrm{E}+02 \pm 1.94 \mathrm{E}+00$ & $\mathrm{pCi} / \mathrm{mL}$ & 1.17E+03 & $3 Q 1-6-1420$ \\
\hline FSP 27001 & 106524 & & & $3.55 \mathrm{E}+01 \pm 9.07 \mathrm{E}-01$ & $\mathrm{pCi} / \mathrm{mL}$ & 4.94E-01 & EPA906.0 \\
\hline FSP 27002 & 108907 & & & $4.17 \mathrm{E}+01 \pm 1.25 \mathrm{E}+00$ & $\mathrm{pCi} / \mathrm{mL}$ & 6.56E-01 & EPA906.0 \\
\hline FSP 29001 & 106523 & & & $2.47 \mathrm{E}+01 \pm 7.63 \mathrm{E}-01$ & $\mathrm{pCi} / \mathrm{mL}$ & 4.82E-01 & EPA906.0 \\
\hline FSP 29002 & 108906 & & & $3.47 \mathrm{E}+01 \pm 1.16 \mathrm{E}+00$ & $\mathrm{pCi} / \mathrm{mL}$ & 6.71E-01 & EPA906.0 \\
\hline HSP 0301 & 106559 & & & $7.80 \mathrm{E}+02 \pm 4.71 \mathrm{E}+00$ & $\mathrm{pCi} / \mathrm{mL}$ & 6.80E-01 & EPA906.0 \\
\hline HSP 0302 & 108923 & & & $1.74 \mathrm{E}+03 \pm 1.09 \mathrm{E}+01$ & $\mathrm{pCi} / \mathrm{mL}$ & $1.38 \mathrm{E}+00$ & EPA906.0 \\
\hline HSP 0401 & 106560 & & & $5.41 \mathrm{E}+02 \pm 3.93 \mathrm{E}+00$ & $\mathrm{pCi} / \mathrm{mL}$ & $6.80 \mathrm{E}-01$ & EPA906.0 \\
\hline HSP 0401A & 106561 & & & $5.49 \mathrm{E}+02 \pm 3.89 \mathrm{E}+00$ & $\mathrm{pCi} / \mathrm{mL}$ & 6.59E-01 & EPA906.0 \\
\hline HSP 0402 & 108924 & & & $3.86 \mathrm{E}+02 \pm 4.48 \mathrm{E}+00$ & $\mathrm{pCi} / \mathrm{mL}$ & $1.03 E+00$ & EPA906.0 \\
\hline HSP 0801 & 106557 & & & $1.80 \mathrm{E}+03 \pm 1.10 \mathrm{E}+02$ & $\mathrm{pCi} / \mathrm{mL}$ & 1.37E+01 & EPA906.0 \\
\hline HSP 0801 & 106557 & & & $1.93 \mathrm{E}+03 \pm 1.16 \mathrm{E}+02$ & $\mathrm{pCi} / \mathrm{mL}$ & $1.41 \mathrm{E}+01$ & EPA906.0 \\
\hline HSP 0802 & 108925 & & & $1.19 \mathrm{E}+03 \pm 7.15 \mathrm{E}+00$ & $\mathrm{pCi} / \mathrm{mL}$ & 8.64E-01 & EPA906.0 \\
\hline HSP 1101 & 106558 & & & $1.48 \mathrm{E}+02 \pm 1.73 \mathrm{E}+00$ & $\mathrm{pCi} / \mathrm{mL}$ & $4.61 \mathrm{E}-01$ & EPA906.0 \\
\hline HSP 1301 & 106556 & & & $1.26 \mathrm{E}+03 \pm 7.90 \mathrm{E}+01$ & $\mathrm{pCi} / \mathrm{mL}$ & $1.29 \mathrm{E}+01$ & EPA906.0 \\
\hline HSP 1302 & 108926 & & & $4.35 \mathrm{E}+02+4.61 \mathrm{E}+00$ & $\mathrm{pCi} / \mathrm{mL}$ & 9.72E-01 & EPA906.0 \\
\hline HSP 1501 & 106555 & & & $5.61 \mathrm{E}+02 \pm 3.51 \mathrm{E}+00$ & $\mathbf{p C i} / \mathbf{m L}$ & 5.17E-01 & EPA906.0 \\
\hline HSP 1502 & 108927 & & & $7.76 \mathrm{E}+02 \pm 5.01 \mathrm{E}+00$ & $\mathrm{pCi} / \mathrm{mL}$ & $6.49 \mathrm{E}-01$ & EPA906.0 \\
\hline HSP 2001 & 106554 & & & $1.80 \mathrm{E}+02 \pm 7.19 \mathrm{E}+00$ & $\mathrm{pCi} / \mathrm{mL}$ & $2.20 \mathrm{E}+00$ & EPA906.0 \\
\hline HSP 2002 & 108928 & & & $2.28 \mathrm{E}+02 \pm 3.34 \mathrm{E}+00$ & $\mathrm{pCi} / \mathrm{mL}$ & $9.65 \mathrm{E}-01$ & EPA906.0 \\
\hline HSP 2501 & 106553 & & & $6.55 \mathrm{E}+02 \pm 2.56 \mathrm{E}+01$ & $\mathrm{pCi} / \mathrm{mL}$ & $4.02 \mathrm{E}+00$ & EPA906.0 \\
\hline
\end{tabular}


ANALYTE: Tritium (continued)

\begin{tabular}{|c|c|c|c|c|}
\hline Survey ID & Sample ID RQ & Result & MDA & Method \\
\hline HSP 2502 & 108929 & $7.99 \mathrm{E}+02 \pm 6.62 \mathrm{E}+00$ & $\mathrm{pCi} / \mathrm{mL} \quad 1.10 \mathrm{E}+00$ & EPA906.0 \\
\hline HSP 2901 & 106552 & $9.77 \mathrm{E}+01 \pm 1.39 \mathrm{E}+00$ & $\mathrm{pCi} / \mathrm{mL} \quad 4.44 \mathrm{E}-01$ & EPA906.0 \\
\hline HSP 2902 & 108930 & $7.04 \mathrm{E}+01 \pm 1.49 \mathrm{E}+00$ & pCi/mL $\quad 6.00 \mathrm{E}-01$ & EPA906.0 \\
\hline HSP 3401 & 106551 & $3.41 \mathrm{E}+02 \pm 4.30 \mathrm{E}+00$ & $\mathrm{pCi} / \mathrm{mL} \quad 1.28 \mathrm{E}+00$ & EPA906.0 \\
\hline HSP 4301 & 106544 & $2.31 \mathrm{E}+03 \pm 1.47 \mathrm{E}+02$ & $\mathrm{pCi} / \mathrm{mL} \quad 1.66 \mathrm{E}+01$ & EPA906.0 \\
\hline HSP 4601 & 106546 & $6.03 \mathrm{E}+02 \pm 3.78 \mathrm{E}+00$ & $\mathrm{pCi} / \mathrm{mL} \quad 5.61 \mathrm{E}-01$ & EPA906.0 \\
\hline HSP 4602 & 108936 & $6.63 \mathrm{E}+02 \pm 6.82 \mathrm{E}+00$ & $\mathrm{pCi} / \mathrm{mL} \quad 1.40 \mathrm{E}+00$ & EPA906.0 \\
\hline HSP 4901 & 106548 & $1.87 \mathrm{E}+03 \pm 1.30 \mathrm{E}+02$ & $\mathrm{pCi} / \mathrm{mL} \quad 4.35 \mathrm{E}+01$ & EPA906.0 \\
\hline HSP 4902 & 108935 & $1.06 \mathrm{E}+03 \pm 9.36 \mathrm{E}+00$ & $\mathrm{pCi} / \mathrm{mL} \quad 1.66 \mathrm{E}+00$ & EPA906.0 \\
\hline HSP 5201 & 106547 & $7.66 \mathrm{E}+03 \pm 3.69 \mathrm{E}+02$ & $\mathrm{pCi} / \mathrm{mL} \quad 2.60 \mathrm{E}+01$ & EPA906.0 \\
\hline HSP 5202 & 108934 & $1.31 \mathrm{E}+03 \pm 7.31 \mathrm{E}+00$ & $\mathrm{pCi} / \mathrm{mL} \quad 8.17 \mathrm{E}-01$ & EPA906.0 \\
\hline HSP $5202 A$ & 108965 & $8.74 \mathrm{E}+03 \pm 1.37 \mathrm{E}+01$ & $\mathrm{pCi} / \mathrm{mL} \quad 5.15 \mathrm{E}-01$ & EPA906.0 \\
\hline HSP 5701 & 106549 & $3.34 \mathrm{E}+02 \pm 2.96 \mathrm{E}+00$ & $\mathrm{pCi} / \mathrm{mL} \quad 6.20 \mathrm{E}-01$ & EPA906.0 \\
\hline HSP $5701 D$ & 106550 & $3.33 \mathrm{E}+02 \pm 2.01 \mathrm{E}+01$ & $\mathrm{pCi} / \mathrm{mL} \quad 5.87 \mathrm{E}+04$ & $3 Q 1-6-1420$ \\
\hline HSP 5702 & 108938 & $1.08 \mathrm{E}+03 \pm 6.41 \mathrm{E}+00$ & $\mathrm{pCi} / \mathrm{mL} \quad 7.60 \mathrm{E}-01$ & EPA906.0 \\
\hline HSP 6001 & 106540 & $1.26 \mathrm{E}+03 \pm 7.75 \mathrm{E}+01$ & $\mathrm{pCi} / \mathrm{mL} \quad 1.06 \mathrm{E}+01$ & EPA906.0 \\
\hline HSP 6401 & 106541 & $1.96 \mathrm{E}+01 \pm 6.64 \mathrm{E}-01$ & $\mathbf{p C i} / \mathbf{m L} \quad 4.47 \mathrm{E}-01$ & EPA906.0 \\
\hline HSP 6402 & 108939 & $2.04 \mathrm{E}+01 \pm 8.53 \mathrm{E}-01$ & $\mathrm{pCi} / \mathrm{mL} \quad$ 6.01E-01 & EPA906.0 \\
\hline HSP 7101 & 106563 & $1.34 \mathrm{E}+03 \pm 5.35 \mathrm{E}+00$ & $\mathrm{pCi} / \mathrm{mL} \quad 5.04 \mathrm{E}-01$ & EPA906.0 \\
\hline HSP 7102 & 108940 & $1.16 \mathrm{E}+03 \pm 6.20 \mathrm{E}+00$ & $\mathrm{pCi} / \mathrm{mL} \quad 6.69 \mathrm{E}-01$ & EPA906.0 \\
\hline HSP 7601 & 106543 & $1.52 \mathrm{E}+02 \pm 1.73 \mathrm{E}+00$ & $\mathrm{pCi} / \mathrm{mL} \quad 4.50 \mathrm{E}-01$ & EPA906.0 \\
\hline HSP 7602 & 108941 & $4.10 \mathrm{E}+02 \pm 3.56 \mathrm{E}+00$ & $\mathrm{pCi} / \mathrm{mL} \quad 6.17 \mathrm{E}-01$ & EPA906.0 \\
\hline HSP 9701 & 106565 & $1.44 \mathrm{E}+03 \pm 9.22 \mathrm{E}+01$ & $\mathrm{pCi} / \mathrm{mL} \quad 1.19 \mathrm{E}+01$ & EPA906.0 \\
\hline HSP 9702 & 108956 & $1.98 \mathrm{E}+03 \pm 7.74 \mathrm{E}+00$ & $\mathrm{pCi} / \mathrm{mL} \quad 6.10 \mathrm{E}-01$ & EPA906.0 \\
\hline HSP 9702A & 108957 & $1.99 \mathrm{E}+03 \pm 7.78 \mathrm{E}+00$ & $\mathrm{pCi} / \mathrm{mL} \quad 6.12 \mathrm{E}-01$ & EPA906.0 \\
\hline HSP 9702A & 108957 & $2.00 \mathrm{E}+03 \pm 7.79 \mathrm{E}+00$ & $\mathrm{pCi} / \mathrm{mL} \quad 6.11 \mathrm{E}-01$ & EPA906.0 \\
\hline HSP 10301 & 106564 & $3.57 \mathrm{E}+02 \pm 1.40 \mathrm{E}+01$ & $\mathrm{pCi} / \mathrm{mL} \quad 2.69 \mathrm{E}+00$ & EPA906.0 \\
\hline HSP 10302 & 108955 & $1.66 \mathrm{E}+03 \pm 5.76 \mathrm{E}+00$ & $\mathrm{pCi} / \mathrm{mL} \quad 4.77 \mathrm{E}-01$ & EPA906.0 \\
\hline
\end{tabular}


This section discusses the generation, processing, and storage of paper and computer records produced during the completion of this project. The processing of the materials follows methodology prescribed by EGG EPD/EMS.

EGG establishes administrative files for each project that are maintained as permanent SRS records. The following materials are placed in the administrative files:

- Bound sample-collection logbooks

- Original copies of the chain-of-custody forms

- Case narratives from the laboratories

- Data-validation logbooks

- Data-entry cover sheets for data files created by EGG

- Copies of all correspondence between data validation personnel and the laboratories

EGG generates computer data files from paper records using double-entry methods to ensure a low transcription error rate. Computer data files for analytical data also are received from the laboratories. Changes to the data are recorded in the data-validation logbook, approved by the project technical manager, and confirmed through a computer program by comparing the modified and original data files. EGG stores the final computer data files, original source files, and computer listings of all changes made to the original files in the administrative files.

Access to the administrative files remains with the manager of EGG. Paper materials eventually will be transferred to permanent box storage; however, EGG plans to make the final data files available to SRS computer users indefinitely. Please contact the manager of EGG to obtain access to this data. 


\section{Appendix F: Glossary}

Acceptance limits: The range of acceptable analytical results established by a laboratory for spike recovery, duplicate precision, and contamination levels.

Accuracy: The closeness of agreement between an observed value and an accepted reference value.

Activity: The rate of decay of a radioactive source at a given time.

Advisory range: The limits of acceptable analytical results established by the provider of certified quality control standards.

Aliquot: A measured portion of a sample taken for analysis.

Analysis: The separation and determination of the component parts or a specific property or element contained within a sample. The determination of the concentration or activity of an analyte contained within a sample.

Analysis date/time: The date and military time (24-hour clock) of the start of analysis on a prepared sample.

\section{Analysis qualifier (AQ): See Qualifier.}

Analyte: The specific compound, element, isotope, or radionuclide of interest that an analyst seeks to determine.

Analytical batch: A group of samples of the same matrix analyzed together using the same method and containing the required number of method blanks, matrix spike samples, laboratory control samples, and duplicate samples.

Analytical narrative: A portion of the data package that includes laboratory, contract, and sample identification. The analytical narrative also contains descriptive documentation of any problems encountered in processing the samples, along with corrective action taken and problems resolved.

Analytical sample: Any solution or medium introduced into an instrument on which an analysis is performed, excluding instrument calibration standards, calibration verification standards, and calibration blanks.

Appendix IX analytes: The list of analytes specified in Appendix IX of the Code of Federal Regulations, Title 40, Part 264 that is required by the Resource Conservation and Recovery Act.

Aquifer: A geologic formation, group of formations, or part of a formation capable of yielding groundwater to wells or springs.

Associated sample: Any sample that is related to another sample or quality control sample. Some examples are the parent sample of a matrix spike, a sample in a preparation batch, a split sample, a duplicate sample, and a sample related to a blank. 
Batch: A group of samples prepared at the same time, in the same location, using the same method.

\section{Bias qualifier (BQ): See Qualifier.}

Blank: An artificial sample designed to monitor the introduction of artifacts into the measurement process. For aqueous samples, deionized water is used as the blank matrix. A universal matrix does not exist for solid samples; therefore, no matrix blank is routinely used. There are several types of blanks that monitor a variety of processes. They are

- A Field Blank for Soils consists of DI water or dry quartz sand placed in a stainless steel bowl and exposed to the atmosphere while the associated sample is being taken. The field blank is shipped to the laboratory with the samples. The field blank measures contamination introduced during sample collection.

- A Field Blank for Groundwater is a sample container filled with DI water and capped in the WSRC well building. It is taken to the field during sampling, but is not opened. It is shipped to the laboratory with the samples to be analyzed.

- A Rinsate or Equipment Blank is deionized water poured appropriately over or through sample collection devices that tests for cleanliness of sampling equipment as well as those activities listed under field blank.

- A Trip Blank is shipped to the laboratory in the same cooler with the sample containers for volatile organic analytes. It provides a test for contamination from sample preservation and transport as well as sample storage, preparation, and. analysis.

- A Method Blank is prepared in the laboratory and analyzed exactly as the samples it accompanies. It is a test for contamination in laboratory sample preparation and analyses.

These blanks are handled by the laboratory as actual samples; however, they are not to be used for matrix spike or duplicate samples.

Blank spike (BS): A method blank to which known concentrations of the analytes of interest are added prior to analysis. The blank spike is subjected to the entire analytical procedure in order to determine the accuracy of the procedure.

Calibration: The establishment of an instrument response curve or mathematical correlation based on the measured response of known concentrations of an analyte or group of analytes.

Calibration blank: A volume of deionized water in the same matrix as the calibration standards, an empty planchet, or the instrument geometry that is analyzed to establish the instrument accuracy at the low end of the calibration curve.

Calibration verification: The periodic analysis of one or more standards independent of the calibration standards to verify the accuracy and stability of the initial instrumen.t calibration.

Cation exchange capacity (CEC): The sum of exchangeable cations a soil can absorb expressed in milli-equivalents per 100 grams of soil. The cation exchange capacity is 
determined by sampling to the depth of solid waste placement and analyzing by the summation method for distinctly acid soils or the sodium acetate method for neutral, calcareous, or saline soils.

Certified value: The known concentration of an analyte in a reference sample as affirmed by the preparer.

Chain-of-custody (COC) form: A document designed to trace the custody of a sample(s) from the point of origin to final disposition, with the intent of legally proving that custody remained intact and that tampering or substitutions were precluded.

Coefficient of variation (CV): The standard deviation as a percent of the arithmetic mean.

Comparability: The degree of confidence with which one set of data can be compared to a related set of data.

Completeness: A measure of the amount of valid data obtained from a measurement system relative to the amount that was expected to be obtained under current, normal conditions.

Comprehensive Environmental Response, Compensation, and Liability Act (CERCLA): A federal law passed in 1980 and periodically modified by the Superfund Amendments and Reauthorization Acts passed by the U.S. Congress. The acts created a special tax that goes into a trust fund, commonly known as Superfund, to investigate and clean up abandoned or uncontrolled hazardous waste sites. Under the program, the U.S. Environmental Protection Agency (EPA) can either

- $\quad$ pay for the site cleanup when parties responsible for the contamination cannot be located or are unwilling or unable to perform the work or

- take legal action to force parties responsible for site contamination to clean up the site or repay the federal government for the cost of the cleanup.

Concentration: The relative fraction of one substance in another, normally expressed in weight percent, volume percent, as a weight per volume ratio, or as a weight per weight ratio.

Confidence limits: The limits within which, at some specified level of probability, the true value of a result lies.

Confined aquifer: An aquifer bounded above and below by impermeable beds or by beds of distinctly lower permeability than of the aquifer itself. Also, an aquifer containing confined groundwater.

Congener: Any one particular member of a class of chemical substances. A specific congener is denoted by a unique chemical structure; e.g., 2,3,7,8-tetrachlorodibenzofuran.

Contaminant: A chemical or biological substance that is harmful if it is incorporated into, onto, or ingested by organisms, consumers of organisms, or users of the environment.

Continuing calibration blank (CCB): A blank analyzed periodically during an analytical run to detect carryover contamination. 
Continuing calibration verification (CCV): The periodic analysis of one or more standards during an analytical run to verify that the initial calibration continues to be valid.

Contract-required quantitation limit (CRQL): The lowest required concentration of an analyte the laboratory may report for a specific contract. The contract-required quantitation limit is usually greater than the method detection limit.

Control limits: A range within which specified measurement results must fall to be compliant. Control limits may be mandatory, requiring corrective action if exceeded, or advisory, requiring that noncompliant data be flagged.

Correlation coefficient (r): A numeric value ( $r$ ) that indicates the degree of dependence between two variables (concentration vs. response). The more dependent they are, the closer the value is to one. The correlation coefficient is determined on the basis of the least squares function.

Custody: Immediate charge, control, or pọssession exercised by a person or competent authority on a sample.

Data quality objectives: The objectives for precision, accuracy, representativeness, completeness, comparability, and detection levels that are required to support the intended use of the data.

Definitive data: Data for which the accuracy of the concentration level as well as the identity of the analyte of interest are assessed. Definitive data is determined for samples considered essential in the decision-making process.

Deionized (DI) water: Water from which all charged species or ionizable organic and inorganic salts are removed by means of ion exchange.

Detection: The act of measuring the quantity of a property, compound, or element contained in a sample.

Dilution factor: The mathematical factor by which a sample is diluted to bring the concentration of an analyte in the sample within the analytical range of the instrument (e.g., $1 \mathrm{~mL}$ of sample $+9 \mathrm{~mL}$ of solvent $=1: 10$ dilution, or a dilution factor of 10 ).

Dry weight: The weight of a sample based on percent solids or the weight after drying in an oven for a specified time period at a specified temperature.

Electronic data deliverable (EDD): The summary of analytical results on machinereadable media received from a laboratory.

Estimated quantitation limit (EQL): The minimum concentration of a substance that can be reliably measured and reported within specified limits of precision and accuracy during routine laboratory operating conditions.

Field blank: See Blank.

Field duplicate: A second sample taken at the same time as the primary sample and sent to the laboratory for analysis as an unknown. The field duplicate is used to determine the precision of the entire sampling and analytical process. 
Field sample: The material received at the laboratory to be analyzed that is contained in single or multiple containers and identified by a unique WSRC sample identification number.

Frequency: The specified intervals between samples that quality control samples or standards must be analyzed during an analytical run.

Groundwater: Water in a saturated zone or stratum beneath the surface of land.

Half-life: The time required for one-half of the initial number of radioactive nuclei of a specific isotopic species to undergo radioactive decay.

Holding time: The maximum amount of time allowed for samples to be held from sample collection to laboratory analysis.

Independent standard: A laboratory-prepared standard solution that is composed of analytes from a different source than those used in the standards for the initial calibration.

Initial calibration: The analysis of standards containing varying concentration levels of the analytes of interest in order to establish the ratio of concentration vs. response across the working range of the analytical technique. The initial calibration is used to define the linearity and dynamic range of response of the detector to the target analytes.

Initial calibration blank (ICB): A blank analyzed immediately after the initial calibration verification but before the analytical run to detect carryover contamination.

Initial calibration verification (ICV): The analysis of one or more standards immediately after the initial calibration but before the analytical run to verify that the initial calibration was valid.

Instrument detection limit (IDL): The minimum concentration of an analyte that can be measured and reported with $99 \%$ confidence that the analyte concentration is greater than zero. It is determined from analysis of a deionized water blank containing the analyte.

Interference check sample (ICS): Two solutions, one consisting of interferents only (ICSA) and one consisting of interferents mixed with the analytes (ICSAB), that are analyzed consecutively to verify the interelement and background correction factors for inductively coupled plasma metal analyses.

Interferents: Substances that affect the analysis for the element of interest.

Interlaboratory comparison: The comparison of results from split samples analyzed by two laboratories.

Internal standard: A chemically inert compound not expected to occur in an environmental sample that is added to a sample prior to analysis; it is used as an instrument response check.

Intralaboratory comparison: The comparison of duplicate results from a single sample analyzed by a laboratory. 
Isomer: One of two or more chemical substances having the same elementary percentage composition and molecular weight but differing in structure and properties.

Isotope: One of a number of specific atoms with identical atomic numbers but with discrete atomic weights or similarly specific atoms whose nuclei have the same number of protons but different numbers of neutrons. -

Laboratory control sample (LCS): A control sample of known composition. Aqueous and solid laboratory control samples are analyzed using the same sample preparation, reagents, and analytical methods employed for the samples received.

Laboratory data records review (LDRR): The investigation of technical data validation issues that are not adequately addressed by the computer checking of EDIs, the review of the analytical narratives, and the review of the COC forms. The review is conducted at the laboratory using the laboratory's instrument logs, raw analytical data, and other pertinent documentation.

Laboratory duplicate: A second aliquot of a homogenized sample that is analyzed as an individual sample, using the same procedure. This duplicate is used to determine the precision of the method.

Laboratory ID: The identifier assigned by the laboratory for its internal use during the analytical process.

Linear range, linear dynamic range: The concentration range over which the calibration curve remains linear.

Lowest practical quantitation limit (LPQL): The lowest concentration of an analyte that can be reliably achieved within specified limits of precision and accuracy during routine laboratory operating conditions.

Matrix: The predominant material of which the sample to be analyzed is composed. For the purpose of this document, a sample matrix is either water or soil/sediment.

Matrix interference: The influence of the sample matrix or sample components upon the ability to quantitatively measure compounds in environmental samples.

Matrix spike/matrix spike duplicate: A first and second aliquot of a matrix fortified (spiked) with a known quantity of analyte(s) and subjected to the entire analytical procedure in order to determine the appropriateness of the method for the matrix by measuring accuracy (recovery) and precision (relative percent difference).

Maximum contaminant level (MCL): The maximum permissible level of a contarninant in a specified medium.

Mean relative difference (MRD): The average of the absolute difference of the results from two laboratories for the $i^{\text {th }}$ sample that is expressed as a percentage of the mean of both laboratories.

Method blank: See Blank. 
Method detection limit (MDL): The minimum concentration of an analyte that can be measured and reported with $99 \%$ confidence that the analyte concentration is greater than zero. It is determined from analysis of a sample in a given matrix containing the analyte.

Minimum detectable activity (MDA): The smallest quantity of a radionuclide that can be detected in a sample with a $95 \%$ confidence level.

Nuclide: General term applied to all isotopes of all elements including stable and radioactive forms. Nuclides are not considered isotopes, rather a given nuclide is characterized by the number of neutrons and protons contained in the atomic nuclei of that species.

Null hypothesis: A statement that can be tested statistically to determine if there is a significant difference between duplicate/split results.

Parts per billion (ppb)/Parts per million (ppm): Units commonly used to express low concentrations of contaminants. For example, five micrograms of benzene in one kilogram of soil is five ppb; three milligrams of nitrate in one liter of water is three ppm.

Percent moisture: An approximation of the amount of water in a soil/sediment sample determined by drying an aliquot of sample at a specified temperature until constant weight is achieved.

Percent recovery: A measure of recovery that is calculated as the measured value relative to the true value, expressed as a percent.

Percent solids: The proportion of solid in a soil/sediment sample determined by the percent moisture procedure.

Performance evaluation sample: A sample of known composition that may be provided by the EPA or WSRC for laboratory analysis that is used to evaluate laboratory performance.

PicoCurie (pCi): The unit of radiation equivalent to $3.7 \times 10^{-2}$ disintegrations per second.

Precision: The agreement or repeatability of a set of replicate results among themselves, usually expressed in terms of the deviation of a set of results from the arithmetic mean. Precision may be qualified in terms of possible sources of variability, replicability, repeatability, and reproducibility.

Preparation log: An official record of the sample preparation.

Preservative: A chemical compound added to a sample or a physical process (such as cooling) to prevent or slow decomposition or degradation of a target analyte. Physical and chemical preservation may be used in tandem to prevent sample deterioration.

Primary laboratory: The laboratory having a contract with WSRC to perform a specific set of analyses for field-generated samples, duplicates, and blanks. A primary laboratory may subcontract this work to other laboratories.

Qualifier: A code used to convey additional information about an analytical result. See the following examples. 
- A Result Qualifier is used to indicate the usability of the result for regulatory driven purposes.

- An Analysis Qualifier is used to describes analytical conditions that apply to the datum. Analysis qualifiers are included here for information only.

- A Bias Qualifier is a code used to indicate whether a result may overestimate or underestimate the true value. It also may be used to indicate poor precision.

See Appendix $D$ for additional information and the specific qualifiers used.

Qualitative analysis: An analysis to determine the presence or absence of a target analyte.

Quality assurance plan: The documented data quality objectives and the actions to be performed to meet those objectives.

Quality control (QC): The performance of actions that provide a means to control and measure the characteristics of measurement equipment and processes to meet the established data quality objectives.

Quantitative analysis: An analysis to measure or determine the amount of a target compound or analyte within the limits of defined precision and accuracy requirements.

Radionuclide: Any radioactive isotope of an element.

Range: The difference between the maximum and minimum values within a set of values.

RCRA Facility Investigation/Remedial Investigation (RFI/RI) program: The EPAregulated investigation of a solid-waste management site, including CERCLA and hazardous-substance regulations, with regard to its potential impact on the environment.

Recovery: A determination of accuracy of the analytical procedure made by comparing measured values for a reference or fortified (spiked) sample against the known true reference or spike values.

Reference detection limit (RDL): The detection limit chosen to allow comparison of multiple analyses with different detection limits. For this report, the individual detection limits of at least $90 \%$ of the analyses are less than the reference detection limit.

Relative percent difference (RPD): A measure of precision that is calculated as the absolute value of the difference between two results, relative to their arithmetic mean, expressed as a percent.

Reporting limit: The value reported in the result field when an analyte is not detected.

Reproducibility: The precision of measurements of the same sample at different laboratories using the same protocols.

Resolution: The degree to which two signal peaks are separated. Resolution is calculated by dividing the height of the valley between the peaks by the peak height of the peak being resolved, multiplied by 100 . 
Resource Conservation and Recovery Act (RCRA): A 1976 federal law that established a regulatory system to define and track hazardous wastes from the time of generation to disposal. The law requires safe and secure procedures to be used in treating, transporting, storing, and disposing of hazardous substances.

Rinsate blank: See Blank.

Run: A continuous analytical sequence consisting of prepared samples and all associated quality control measurements.

Sample: A portion of material to be analyzed that is contained in single or multiple containers and identified by a unique sample number.

Sample ID: A unique identification number designated by WSRC for each sample. The WSRC sample ID appears on the sample chain of custody that documents information on that sample.

Sample matrix: All of the chemical components and physical characteristics of a sample other than the parameter of interest.

Sample-specific estimated quantitation limit (ssEQL): The estimated quantitation limit multiplied by factors of concentration, dilution, aliquot size, and percent solids.

Sediment: The unconsolidated inorganic and organic material that is suspended in, and being transported by surface water, or has settled out and deposited into beds.

Self-absorption: The internal absorption of radiation emitted by radioactive atoms by material in which the radioactive atoms are located.

Sensitivity: The ability of a measurement system to detect and accurately quantitate a parameter at a critical level within a specific sample matrix. The critical level may be a regulatory $\mathrm{MCL}, \mathrm{MDA}$, or risk-based exposure level.

Significance of probability: The probability of observing a statistical value as significant as, or even more significant than, the value actually observed.

Soil: All unconsolidated materials normally found on or near the surface of the earth including, but not limited to, silts, clays, sands, gravel, and small rocks.

Solvent: Liquid that is capable of dissolving another substance.

Split sample: A second aliquot of a sample, generated in the field, that is sent to a secondary laboratory for analysis; a split sample serves as a quality control check.

Standard deviation: The measurement of dispersion about a mean value of a series of observations expressed in the same units as the mean value.

Surface water: All water that is open to the atmosphere and subject to surface runoff.

Surrogate: A chemically inert organic compound similar in composition and test performance to an analyte of interest that is added to samples prior to analysis as a quality control check. 
Surrogate recovery: A quality control méeasurement to monitor unusual matrix effects, gross sample processing errors, etc. It is evaluated for acceptance by determining whether the measured concentration falls within the statistical acceptance limits established by the laboratory.

Target analyte list (TAL): The list of inorganic analytes required by CERCLA.

Target compound list (TCL): The list of organic analytes required by CERCLA.

Technical holding time: The storage time allowed between sample collection and sample analysis when designated preservation and storage techniques are employed. This is determined by the elapsed time in days from the date and time of collection to the date and time of sample preparation and analysis.

- Technical holding time $=$ (sample analysis date and time - sample collection date and time).

Tentatively identified compound (TIC): Chromatographic peak in volatile and semivolatile fraction analysis that is not a target analyte, surrogate, or internal stanidard.

Time: When required to record time on any deliverable item, time shall be expressed as military time, i.e., on a 24 -hour clock.

Toxicity characteristic leaching procedure (TCLP): An analytical extraction procedure used to determine the mobility of both inorganic and organic analytes present in solid, liquid, and multiphasic wastes.

Tracer: A quantity of a unique radioisotope of the same element added to a sample, chemically prepared, or separated and counted. The quantity of tracer measured is compared to the quantity of target radioactive element measured, and the target quantity is calculated on the basis of unity with the tracer concentration.

Trip blank: See Blank.

Wet weight: The weight of a sample aliquot including moisture (undried). 